Prepared in cooperation with the U.S. Department of Agriculture Natural Resources Conservation Service and Farm Service Agency

\title{
The Integrated Landscape Modeling Partnership_Current Status and Future Directions
}

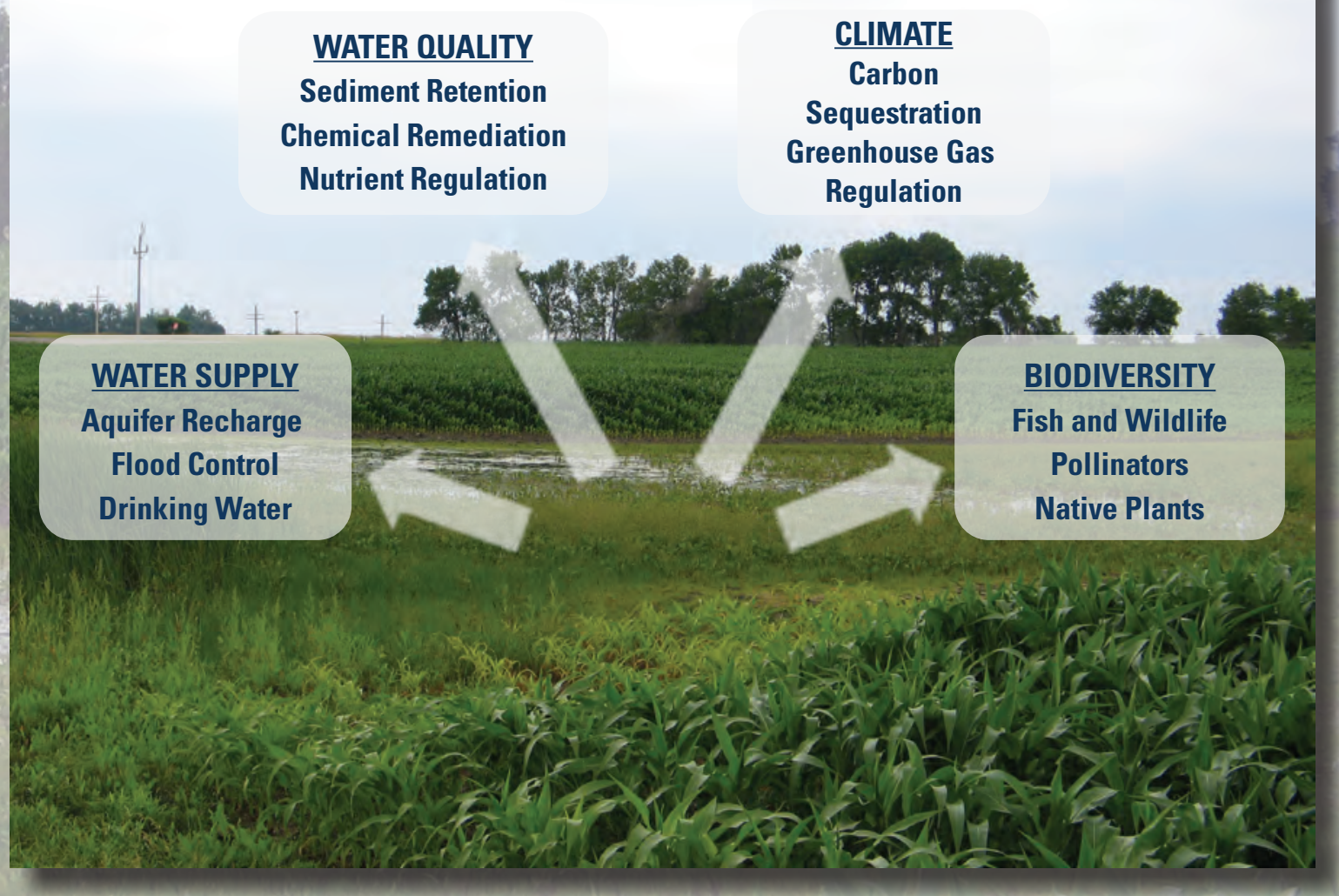

Open-File Report 2016-1006

Version 1.1, December 2016

U.S. Department of the Interior

U.S. Geological Survey 
Cover photograph. Potential ecosystem services provided by a cropland wetland located near Jamestown, North Dakota (photograph by David Mushet, U.S. Geological Survey, July 28, 2004). 


\section{The Integrated Landscape Modeling Partnership-Current Status and Future Directions}

By David M. Mushet and Eric J. Scherff

Prepared in cooperation with the U.S. Department of Agriculture Natural

Resources Conservation Service and Farm Service Agency

Open-File Report 2016-1006

Version 1.1, December 2016

U.S. Department of the Interior

U.S. Geological Survey 


\title{
U.S. Department of the Interior SALLY JEWELL, Secretary
}

\section{U.S. Geological Survey Suzette M. Kimball, Director}

\author{
U.S. Geological Survey, Reston, Virginia: 2016 \\ First release: 2016 \\ Revised: December 2016 (ver. 1.1)
}

\begin{abstract}
For more information on the USGS - the Federal source for science about the Earth, its natural and living resources, natural hazards, and the environment—visit http://www.usgs.gov or call 1-888-ASK-USGS.

For an overview of USGS information products, including maps, imagery, and publications, visit http://www.usgs.gov/pubprod/.
\end{abstract}

\author{
Any use of trade, firm, or product names is for descriptive purposes only and does not imply endorsement by the \\ U.S. Government. \\ Although this information product, for the most part, is in the public domain, it also may contain copyrighted materials \\ as noted in the text. Permission to reproduce copyrighted items must be secured from the copyright owner. \\ Suggested citation: \\ Mushet, D.M., and Scherff, E.J., 2016, The integrated landscape modeling partnership—Current status and \\ future directions (ver. 1.1, December 2016): U.S. Geological Survey Open-File Report 2016-1006, 59 p., \\ http://dx.doi.org/10.3133/ofr20161006.
}

ISSN 2331-1258 (online) 


\section{Contents}

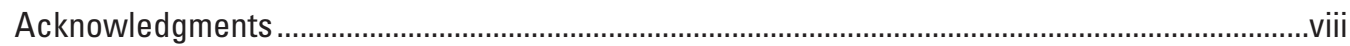

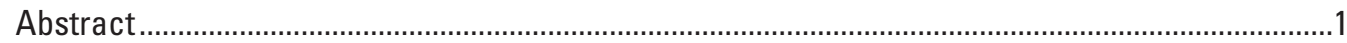

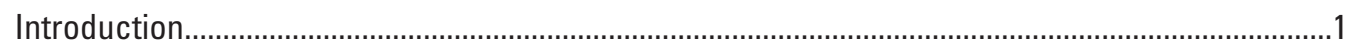

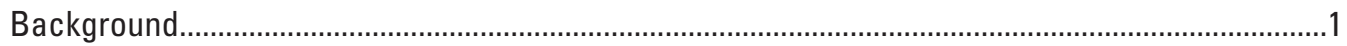

History of the Integrated Landscape Modeling Partnership ...................................................2

Regional Assessments and Data Availability for Integrated Landscape Modeling ..................4

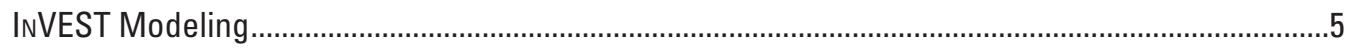

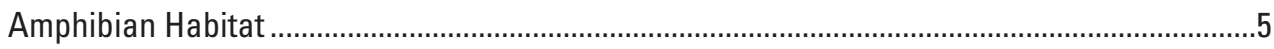

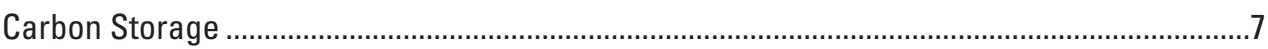

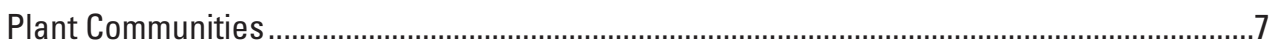

Pollination Services.........................................................................................................

Waterfowl and Grassland Bird Habitat...............................................................................

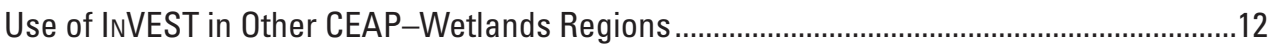

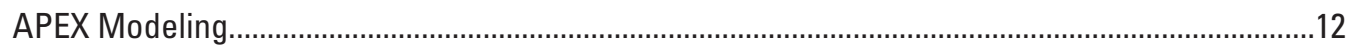

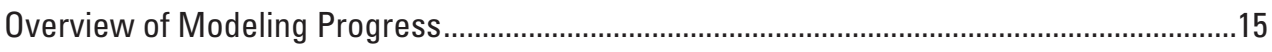

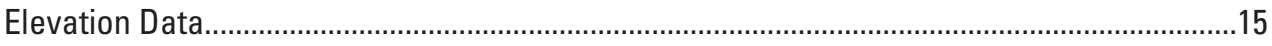

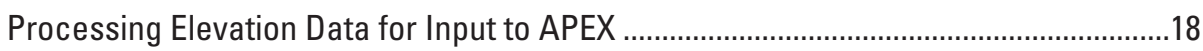

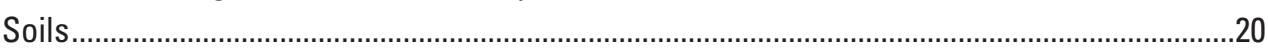

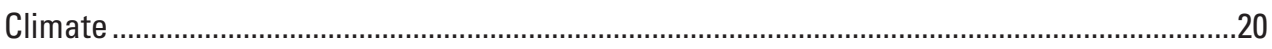

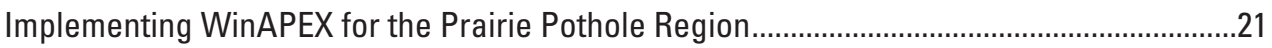

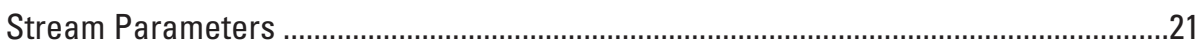

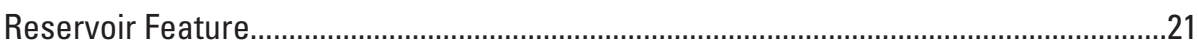

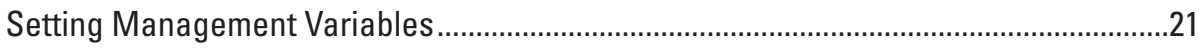

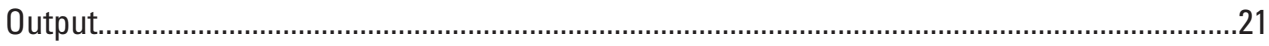

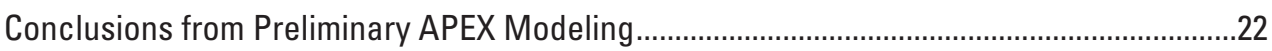

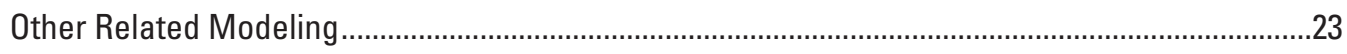

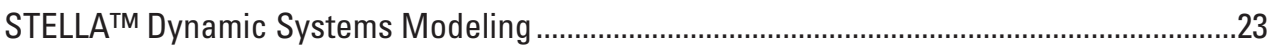

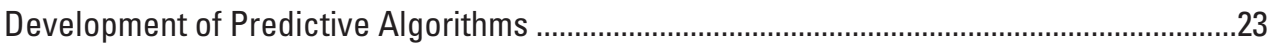

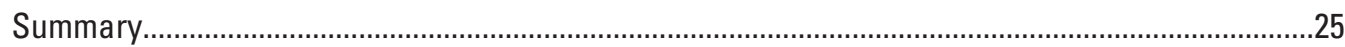

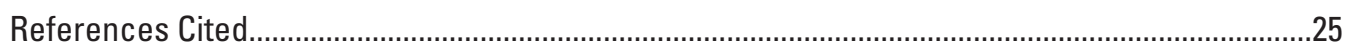

Appendix 1. Memorandum of Understanding .............................................................................30

Appendix 2. Completed Integrated Valuation of Ecosystem Services and Tradeoffs Threat and Susceptibility Tables used in Evaluations of Amphibian Habitat in the Prairie Pothole Region of the United States

Appendix 3. Vegetation (Living and Dead) and Soil (Organic and Inorganic) Carbon Pool Estimates in Megagrams per Hectare for the Northern and Northwestern Glaciated Plains Ecoregions.

Appendix 4. Completed Integrated Valuation of Ecosystem Services and Tradeoffs Threat and Susceptibility Tables used in Evaluations of Native Plant Communities in the Prairie Pothole Region of the United States

Appendix 5. A Geographic Information System Tool to Project Managed and Wild Bees on Any Landscape......

Appendix 6. Floral Resource Values for Land-Cover Types used in Integrated Valuation of Ecosystem Services and Tradeoffs Managed Bee Model Runs. 
Appendix 7. Select Subarea Settings Used in Agricultural Policy/Environmental Extender

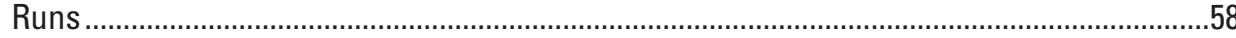

Appendix 8. Select Control File Settings Used in Agricultural Policy/Environmental

Extender Runs. 59

\section{Figures}

1. Map showing physiographic regions of the United States to be evaluated under the wetlands component of the Conservation Effects Assessment Project 4

2. Maps showing amphibian habitat quality of the Prairie Pothole Region of the United States under current Conservation Reserve Program enrollment conditions, a scenario in which 100 percent of CRP grasslands are converted to cropland, and difference between 2012 conditions and 100 percent CRP conversion scenario.

3. Maps showing carbon stores of the Prairie Pothole Region of the United States under current Conservation Reserve Program enrollment conditions, a scenario in which 100 percent of CRP grasslands are converted to cropland, and difference between 2012 conditions and 100 percent CRP conversion scenario

4. Maps showing native plant floristic quality of prairie pothole wetlands of the United States under current Conservation Reserve Program enrollment conditions, a scenario in which 100 percent of CRP grasslands are converted to cropland, and difference between 2012 conditions and 100 percent CRP conversion scenario

5. Maps showing managed bee floral resources quality of the Prairie Pothole Region of the United States under current Conservation Reserve Program enrollment conditions, a scenario in which 100 percent of CRP grasslands are converted to cropland, and difference between 2012 conditions and 100 percent CRP conversion scenario

6. Graphs showing population trends of gadwall and northern pintail, 1955 to 2014 ..........14

7. Graph showing North American breeding bird survey population index for the grasshopper sparrow in the central Mixed-Grass Prairie region, 1967 to 2012.

8. Diagram showing ArcGIS Desktop Model Builder diagram of the automated workflow developed to select the lowest elevation sink in each basin and create a single feature class of all such sinks.

9. Two schematic diagrams of alternate subarea configurations for a wetland basin in the Agricultural Policy/Environmental Extender model that could flood subareas 1 and 2, and also allow overflow to the adjacent basin

10. Configuration of the six subareas being used in the Agricultural

Policy/Environmental Extender model of the basin for wetland T1

11. Graph showing results from a STELLA ${ }^{\mathrm{TM}}$ systems model simulation of water levels in a prairie pothole region wetland over a 24 -year period. 


\section{Tables}

1. Area of amphibian habitat in the Prairie Pothole region of the United States with a habitat quality rating greater than or equal to 0.8 under scenarios representing the conversion of various percentages of Conservation Reserve Program grasslands to croplands

2. Results of Integrated Valuation of Ecosystem Services and Tradeoffs carbon model runs for the Prairie Pothole region of the United States under scenarios representing the conversion of various percentages of Conservation Reserve Program grasslands to croplands.

3. Carbon dioxide released into the atmosphere under scenarios representing the conversion of various percentages of Conservation Reserve Program grasslands to croplands.

4. Societal costs of increased levels of atmospheric carbon dioxide due to carbon releases in the Prairie Pothole Region of the United States under scenarios representing the conversion of various percentages of Conservation Reserve Program grasslands to croplands.

5. Wetland area in the Prairie Pothole region of the United States with native plant-community floristic quality ratings greater than 0.5 .

6. Area of the Prairie Pothole region of the United States with a floral resources quality score greater than 0.25 under scenarios representing the conversion of various percentages of Conservation Reserve Program grasslands to croplands.

7. Algorithms developed by the CEAP-Wetlands High Plains regional assessment team for predicting amphibian species richness and probability of individual species being present in High Plains playa wetlands

\section{Appendix Tables}

2-1. Integrated Valuation of Ecosystem Service and Tradeoffs threat table for amphibian habitat model.

2-2. Integrated Valuation of Ecosystem Service and Tradeoffs susceptibility table for amphibian habitat model

3-1. Vegetation and soil carbon pool estimates in megagrams per hectare for the Northwestern and Northern Glaciated Plains ecoregions.

4-1. Integrated Valuation of Ecosystem Services and Tradeoffs threat table for plant community model.

4-2. Integrated Valuation of Ecosystem Services and Tradeoffs susceptibility table for plant community model.

6-1. Floral resource values for land-cover types used in Integrated Valuation of Ecosystem Services and Tradeoffs managed bee model runs.

7-1. Select subarea settings used in Agricultural Policy/Environmental Extender runs .......58

8-1. Select control file settings used in Agricultural Policy/Environmental Extender runs ...59 


\section{Conversion Factors}

[International System of Units to Inch/Pound]

\begin{tabular}{lcl}
\hline \multicolumn{1}{c}{ Multiply } & By & \multicolumn{1}{c}{ To obtain } \\
\hline centimeter $(\mathrm{cm})$ & Length & inch (in) \\
millimeter $(\mathrm{mm})$ & 0.3937 & inch (in) \\
meter $(\mathrm{m})$ & 0.03937 & foot (ft) \\
kilometer $(\mathrm{km})$ & 3.281 & mile (mi) \\
\hline & 0.6214 & acre \\
\hline square meter $\left(\mathrm{m}^{2}\right)$ & Area & acre \\
hectare $($ ha $)$ & 0.0002471 & ounce, fluid (fl. oz) \\
\hline & 2.471 & foot per minute $(\mathrm{ft} / \mathrm{min})$ \\
liter $(\mathrm{L})$ & Volume & inches per hour $(\mathrm{in} / \mathrm{h})$ \\
\hline meter per minute $(\mathrm{m} / \mathrm{m})$ & 33.82 & \\
millimeters per hour $(\mathrm{mm} / \mathrm{h})$ & Flow Rate & ounce, avoirdupois $(\mathrm{oz})$ \\
\hline & 3.281 & ton, long $(2,240 \mathrm{lb})$ \\
\hline gram $(\mathrm{g})$ & 0.03937 & Mass
\end{tabular}

Temperature in degrees Celsius $\left({ }^{\circ} \mathrm{C}\right)$ may be converted to degrees Fahrenheit $\left({ }^{\circ} \mathrm{F}\right)$ as follows: ${ }^{\circ} \mathrm{F}=\left(1.8 \times{ }^{\circ} \mathrm{C}\right)+32$.

Temperature in degrees Fahrenheit $\left({ }^{\circ} \mathrm{F}\right)$ may be converted to degrees Celsius $\left({ }^{\circ} \mathrm{C}\right)$ as follows: ${ }^{\circ} \mathrm{C}=\left({ }^{\circ} \mathrm{F}-32\right) / 1.8$.

\section{Supplemental Information}

Note to USGS users: Use of hectare (ha) as an alternative name for square hectometer $\left(\mathrm{hm}^{2}\right)$ is restricted to the measurement of small land or water areas. Use of liter $(\mathrm{L})$ as a special name for cubic decimeter $\left(\mathrm{dm}^{3}\right)$ is restricted to the measurement of liquids and gases. No prefix other than milli should be used with liter. Metric ton (t) as a name for megagram (Mg) should be restricted to commercial usage, and no prefixes should be used with it. 


\section{Abbreviations}

\begin{tabular}{|c|c|}
\hline APEX & Agricultural Policy/Environmental Extender \\
\hline ARIES & Artificial Intelligence for Ecosystem Services \\
\hline CEAP & Conservation Effects Assessment Project \\
\hline CHD & channel depth \\
\hline $\mathrm{CHL}$ & channel length \\
\hline CHN & channel roughness (Manning's N) \\
\hline CHS & channel slope \\
\hline CLSA & Cottonwood Lake study area \\
\hline $\mathrm{CO}_{2}$ & carbon dioxide \\
\hline CRP & Conservation Reserve Program \\
\hline DEM & digital elevation model \\
\hline DES & Des Moines Lobe \\
\hline DOI & U.S. Department of the Interior \\
\hline FSA & Farm Service Agency \\
\hline GIS & geographic information system \\
\hline GPS & global positioning system \\
\hline ha & hectare \\
\hline ILM & integrated landscape modeling \\
\hline ILMRI & Integrated Landscape Monitoring Research Initiative \\
\hline InVEST & Integrated Valuation of Ecosystem Services and Tradeoffs \\
\hline LAP & Lake Agassiz Plain \\
\hline lidar & light detection and ranging \\
\hline METSTAT & Meteorological/Statistical solar radiation model \\
\hline $\mathrm{Mg}$ & megagrams \\
\hline $\mathrm{mm}$ & millimeters \\
\hline $\mathrm{mm} / \mathrm{h}$ & millimeters per hour \\
\hline $\mathrm{m} / \mathrm{m}$ & meters per minute \\
\hline NGP & Northern Glaciated Plains \\
\hline NLCD & National Land Cover Database \\
\hline NRCS & Natural Resources Conservation Service \\
\hline NSRDB & National Solar Radiation Database \\
\hline NWGP & Northwestern Glaciated Plains \\
\hline NWI & National Wetlands Inventory \\
\hline PPR & Prairie Pothole Region \\
\hline
\end{tabular}




$\begin{array}{ll}\text { RCHC } & \text { crop management channel factor } \\ \text { RCHK } & \text { erodibility channel factor } \\ \text { RCHL } & \text { channel routing reach length } \\ \text { RFPW } & \text { buffer/floodplain width } \\ \text { RSBD } & \text { bulk density of sediments in reservoir } \\ \text { RSDP } & \text { days required for reservoir to return to normal conditions } \\ \text { RSHC } & \text { reservoir hydraulic conductivity } \\ \text { RSRR } & \text { reservoir return rate } \\ \text { RSYN } & \text { normal sediment concentration in reservoir } \\ \text { RSYS } & \text { initial sediment concentration in reservoir } \\ \text { SSURGO } & \text { Soil Survey Geographic Database } \\ \text { USDA } & \text { U.S. Department of Agriculture } \\ \text { USGS } & \text { U.S. Geological Survey } \\ \text { USLE } & \text { Universal Soil Loss Equation } \\ \text { winAPEX } & \text { APEX for Windows }{ }^{2}\end{array}$

\section{Acknowledgments}

External funding for the ILM Partnership was provided by the Conservation Effects Assessment Project of the U.S. Department of Agriculture's Natural Resources Conservation Service and the Monitoring, Assessment and Evaluation Program of the U.S. Department of Agriculture's Farm Service Agency. 


\title{
The Integrated Landscape Modeling Partnership-Current Status and Future Directions
}

\author{
By David M. Mushet and Eric J. Scherff
}

\section{Abstract}

The Integrated Landscape Modeling (ILM) partnership is an effort by the U.S. Geological Survey (USGS) and U.S. Department of Agriculture (USDA) to identify, evaluate, and develop models to quantify services derived from ecosystems, with a focus on wetland ecosystems and conservation effects. The ILM partnership uses the Integrated Valuation of Ecosystem Services and Tradeoffs (INVEST) modeling platform to facilitate regional quantifications of ecosystem services under various scenarios of land-cover change that are representative of differing conservation program and practice implementation scenarios. To date, the ILM INVEST partnership has resulted in capabilities to quantify carbon stores, amphibian habitat, plant-community diversity, and pollination services. Work to include waterfowl and grassland bird habitat quality is in progress. Initial INVEST modeling has been focused on the Prairie Pothole Region (PPR) of the United States; future efforts might encompass other regions as data availability and knowledge increase as to how functions affecting ecosystem services differ among regions.

The ILM partnership is also developing the capability for field-scale process-based modeling of depressional wetland ecosystems using the Agricultural Policy/Environmental Extender (APEX) model. Progress was made towards the development of techniques to use the APEX model for closed-basin depressional wetlands of the PPR, in addition to the open systems that the model was originally designed to simulate. The ILM partnership has matured to the stage where effects of conservation programs and practices on multiple ecosystem services can now be simulated in selected areas. Future work might include the continued development of modeling capabilities, as well as development and evaluation of differing conservation program and practice scenarios of interest to partner agencies including the USDA's Farm Service Agency (FSA) and Natural Resources Conservation Service (NRCS). When combined, the ecosystem services modeling capabilities of INVEST and the process-based abilities of the APEX model should provide complementary information needed to meet USDA and the Department of the Interior information needs.

\section{Introduction}

Ecosystems provide multiple provisioning, regulating, cultural, and supporting services important to societies across the globe (Millennium Ecosystem Assessment, 2005). Provisioning services are services that directly benefit a society by providing food, fuel, water, and other valued products. Regulating services benefit societies through their effects on events such as flooding, pesticide transport, and disease spread.

Cultural services are the spiritual, religious, educational, recreational, and other, often nonmaterial, benefits received from having intact ecosystems on a landscape. Finally, supporting services are ecosystem functions and processes, such as nutrient cycling, soil formation, and primary production, that support all previously mentioned provisioning, regulating, and cultural services. Thus, supporting services are analogous to the functions and processes typically associated with wetlands and other ecosystems (Euliss and others, 2013, p. 187). Given not only the global importance of ecosystem services to societies and the vulnerability of natural ecosystems to threats associated with changing land uses and management practices, but also the potential to enhance services through targeted implementation of conservation programs and practices, there is great value in developing tools to facilitate the quantification of ecosystem services under differing land-use and land-management scenarios. In this report, we provide information on the status and potential future directions of a U.S. Geological Survey (USGS) and U.S. Department of Agriculture (USDA) partnership to develop ecosystem service quantification tools and to use these tools to evaluate effects of conservation programs and practices on ecosystem services of value to society.

\section{Background}

Integrated Landscape Modeling (ILM), as being used within this USGS-USDA partnership, is (1) the identification, evaluation, and development of models that quantify all types of ecosystem services; and (2) the integration of model outputs 
in a manner that facilitates the formation of a holistic vision of the effects of land use and land management on multiple services provided by ecosystems across a given landscape. The overarching vision of the ILM partnership (Euliss and others, 2010) called for a modeling system that would provide for the simultaneous quantification of multiple ecosystem services and that also could use monitoring data that would facilitate model adaptation to increasingly robust datasets. Thus, part of the "integration" described by Euliss and others (2010) was the linking of ecosystem models with monitoring. The result would be an adaptive modeling system fused to a monitoring network capable of providing simultaneous forecasts of diverse ecosystem services for use in identifying management and policy options for sustainable management of ecosystems. Euliss and others (2010, p. 7762) correctly described the development of such a system as a "daunting" task but stated that it was possible within current (2010) technical capabilities.

\section{History of the Integrated Landscape Modeling Partnership}

In response to information needs related to Federal wetland restoration programs in the Prairie Pothole Region (PPR) of the United States, an extensive survey of restored prairie pothole wetlands and adjacent uplands was completed by USGS in 2004 to facilitate quantifications of ecosystem services derived from U.S. Department of the Interior (DOI) and USDA conservation programs (Gleason and others, 2008). Funding for the survey was provided by the USDA Farm Service Agency (FSA) through their Monitoring, Assessment, and Evaluation Program; USDA Natural Resources Conservation Service (NRCS) through the Conservation Effects Assessment Project (CEAP); and USGS. In general, agencies had similar research interests and information needs, but no single agency had sufficient funds to evaluate the array of wetland functions affecting the diverse ecological services provided by these wetland ecosystems; therefore, recognizing the importance of quantifying concurrent ecosystem services, the partner agencies designed a study to evaluate a broad suite of wetland functions across a larger spatial gradient. Data from this survey were analyzed in a published report that summarizes environmental changes in the PPR attributable to DOI and USDA conservation programs (Gleason and others, 2008).

Both DOI and USDA seek to quantify benefits not only of federally funded practices and programs but also of all wetland conservation practices, whether funded in whole or part by Federal agencies, States, local municipalities, or the landowners themselves; however, information collected as part of the 2004 survey (Gleason and others, 2008) provided only a "point-in-time" estimate of the environmental benefits, and only for a discrete set of conservation practices. To overcome such limitations, the ILM partnership was formed to develop cost-effective, standardized, and efficient techniques to quantify ecosystem services within a framework that would allow for the estimation of future ecological changes attributable to multiple and diverse conservation programs and practices.

In 2006, the USGS initiated a separate Integrated Landscape Monitoring Research Initiative (ILMRI). The overarching goals of the ILMRI were to observe, understand, and predict change in environmental services as the landscape changed and to evaluate the implications on natural resources at multiple spatial and temporal scales in order to address priority natural resource management and policy issues. The program sought to be responsive to management needs; to operate as collaborative multidisciplinary and multiagency teams; to remain driven by questions that bridge management and science; to seek results and approaches that were transferable and interoperable; to leverage existing knowledge, information, programs, and capabilities; and to provide approaches and tools that were feasible, practical, achievable, and cost effective. The USGS ILMRI teams were organized and focused on pilot projects in the PPR, Lower Mississippi Valley, Great Basin, and Puget Sound, respectively, with the goal of increasing knowledge of ecological processes with these four focal regions. The ILMRI operated from 2006 to 2009 exploring development of conceptual and other models, with one important outcome being the establishment of a Memorandum of Understanding between partner agencies that also included the U.S. Fish and Wildlife Service (appendix 1).

During the period that the USGS ILMRI was in operation, assessment efforts similar to the 2004 extensive survey of PPR wetlands (Gleason and others, 2008) were initiated in other regions of the United States as part of the Wetlands Component of the National USDA CEAP effort (CEAPWetlands). The CEAP-Wetlands effort and the ILMRI had complementary goals, with CEAP-Wetlands being focused more specifically on working agricultural lands and the effects of USDA conservation programs and practices. Although the regions used in the ILMRI and CEAP-Wetlands efforts were largely unique, two regions (PPR and lower Mississippi Alluvial Valley) were common between efforts. When the ILMRI ended in 2009, the ILM moniker was assimilated into CEAP-Wetlands and model development continued. As this change occurred, funding from the FSA Monitoring, Assessment, and Evaluation Program continued to be instrumental. The primary focal area for the ILM partnership remained in the PPR but with the goal of expanding to other CEAP-Wetlands regions in the future as modeling capabilities matured and as data from other regional assessments became available. A number of recent studies addressing wetland functions and services have been completed by other regional teams, including the mid-Atlantic (McFarland and others, in press; Kluber and others, 2014; Yepsen and others, 2014; Fenstermacher and others, 2014), the High Plains (O'Connell and others, 2012; Venne and others, 2012; Daniel and others, 2014; Beas and Smith, 2015; Daniel and others, 2015a,b), and the California Central Valley (Duffy and others, 2011). These studies will provide the background data necessary to initiate expansion of the ILM into these regions and facilitate development of other ecosystem services modeling capabilities, such as nutrient 
regulation and hydrologic flow modeling (Denver and others, 2014; Hunt and others, 2014; McDonough and others, 2014; Ator and others, 2013), and the techniques necessary to predict the provision of services (Huang and others, 2014; Lang and others, 2013).

The ILM partnership originally focused on developing a single, all-encompassing modeling system that would simulate wetland and landscape process across a given region and provide quantitative output of multiple services in response to changing land uses, climate change, management, or other scenarios. Development of this "EcoServ" modeling system was led by the USGS in Sioux Falls, South Dakota. As with the broad ILM partnership, the vision of the EcoServ model was ambitious. At its core, the modeling system needed to simulate numerous complex hydrologic, geochemical, and biotic processes that shape and affect not just wetland ecosystems but also the surrounding terrestrial ecosystem processes that ultimately lead to the provisioning of services. Also, the system was designed to be openly shared and accessed over the internet through the use of distributed geographic information system (GIS) techniques and open geospatial standards (Feng and others, 2011).

The data initially collected during the CEAP-Wetlands regional assessments surveys did not encompass all variables needed to facilitate EcoServ modeling efforts, nor did the sampling approaches provide the temporal resolution needed to support development and parameterization of the envisioned modeling system. Due to these limitations, EcoServ model development began by focusing on the USGS's Cottonwood Lake Study Area in Stutsman County, North Dakota. The Cottonwood Lake Study Area is a long-term (several decades) ecosystem-monitoring site with detailed hydrologic, chemical, and biotic data for multiple wetland basins within an interconnected wetland complex (Winter, 2003).

Substantial progress was made in 2009 and early 2010 in developing the EcoServ modeling system so that it could accurately simulate water levels and changes in vegetative zones in wetlands of the Cottonwood Lake Study Area wetlands in response to changes in climate. Although much was learned from the effort, it was unclear how the system could be expanded beyond the Cottonwood Lake Study Area to other areas where the detailed data needed to calibrate and validate the model were not available. The modeling system was operating at a level beyond the current range of knowledge and data availability; furthermore, the funding levels required to expand its operability and adaptive capabilities to allow linkage to an as yet undefined monitoring system were not available within the ILM partnership. In mid-2010, a joint decision by the partner agencies shifted the available resources to focus on evaluating more recently available decision-support tools that could facilitate assessments of ecosystem services.

The two most promising open-source ecosystem services decision-support tools are the Integrated Valuation of
Ecosystem Services and Tradeoffs (INVEST; Natural Capital Project, 2013) and the Artificial Intelligence for Ecosystem Services (ARIES; Villa and others, 2014) models (Vigerstol and Aukema, 2011). The InVEST suite of desktop tools is able to model and map ecosystem services and quantify landscapelevel patterns and changes in ecosystem services that result from land-cover or climate changes. By contrast, ARIES is a web-based modeling tool that allows for the evaluation of trade-offs between ecosystem services. Key to the ARIES system is its focus on the transfer of services from where they are produced to where benefits occur. Ultimately, INVEST was selected as the most appropriate modeling system to use within the ILM partnership. The decision was primarily due to a lack of ability to model habitat-provisioning services within ARIES; quantifying benefits of conservation programs and practices to wildlife populations and other biota was considered essential to meet overall ecosystem-services quantification goals. However, two advantages of the ARIES tool are (1) its use of agent-based models to quantify the flow of ecosystem services between areas where the services are produced and areas where human benefactors are located, thereby separating actual as opposed to theoretical provisioning of services; and (2) the system's ability to quantify uncertainties through the use of Bayesian network modeling and Monte Carlo simulation. Thus, if habitat-provisioning services become a part of the future modeling capabilities of ARIES, a second look at this powerful ecosystem services modeling tool may be warranted.

From 2011 to 2015, the ILM partnership has developed INVEST modeling to quantify a variety of services generated on a landscape under various land-cover scenarios. Partners can inform these scenarios so that they provide a representation of differing conservation programs and practices. In the examples described herein, model testing for the PPR region has focused on identifying changes in services under scenarios representing land-cover change that would result from varying percentages of Conservation Reserve Program (CRP) grassland contracts expiring and being returned to crop production; however, the need to relate ecosystem service quantifications to process-based models at field scales is still recognized. Thus, in 2013-14 the ILM partnership began exploring the potential of the Agricultural Policy/Environmental Extender (APEX) model. The APEX model facilitates biophysical process-based simulations of small basins. Considerable progress was made towards developing techniques to model closed-basin depressional wetlands of the PPR, expanding beyond the open-flow systems that the model was originally designed to simulate. APEX modeling is ongoing and is currently being led by the CEAP Modeling Team in Temple, Texas. When combined, the ecosystem services modeling capabilities of INVEST and the process-based abilities of APEX should provide complementary information needed to meet USDA and DOI information needs. 


\section{Regional Assessments and Data Availability for Integrated Landscape Modeling}

The primary source of data available, for model development and validation, has come from seven physiographic regions of the United States, Glacial Interior Plains, Prairie Pothole Region, Gulf Atlantic Coastal Flats, High Plains, Mississippi Alluvial Valley, California Central Valley, and GulfAtlantic Rolling Plains, corresponding to the areas covered under CEAP-Wetlands regional assessments (fig. 1). Within these regions, detailed data on wetlands and surrounding upland ecosystems were collected. As previously mentioned, the first regional assessment was completed in the PPR in 2004; it was built on an earlier 1997 assessment that only included seasonal and semi-permanent wetlands (Gleason and others, 2008). Many of the wetland catchments surveyed in 1997 were resampled in the 2004 assessment, and additional wetlands were added to include temporary wetlands within the sample population. The overall sample design used in the 2004 PPR regional assessment (Gleason and others, 2008) was used as the initial framework for sampling in the other regions. Key to the design was the sampling of wetlands across a disturbance gradient spanning drained wetlands within actively farmed croplands, wetlands within idle croplands that had been planted to perennial cover (for example, CRP grasslands, WRP easements), and wetlands within noncropped native grasslands.

Efforts were made to standardize sampling techniques across assessment regions as each region began its surveys, but numerous adjustments were needed to accommodate the unique environmental characteristics and scientific interests and capabilities in each region. Thus, available data and sampling techniques varied considerably among regions. Sampling designs and wetland types were most similar between the PPR and High Plains (potholes and playas, respectively), whereas in other regions the wetland

Figure 1. Physiographic regions of the United States to be evaluated under the wetlands component of the Conservation Effects Assessment Project (CEAP_ Wetlands). Data collection efforts have occurred in 7 of the 11 regions: Glacial Interior Plains (1), Prairie Pothole Region (3), Gulf Atlantic Coastal Flats (4), High Plains (7), Mississippi Alluvial Valley (8), California Central Valley (9) and Gulf-Atlantic Rolling Plains (10). systems and sampling approaches differed in many details, apart from a common theme of sampling across a disturbance gradient. This regional variation in techniques, variables measured, and ecosystem services evaluated complicated the ability to develop a shared modeling system for quantifying ecosystem services across regions (as in the EcoServ model); however, the sampling-method variability reflects the distinctive differences among regional wetland systems.

A comparison of the PPR and lower Mississippi Alluvial Valley regions indicates these differences. An important ecosystem service in the PPR is the provisioning of waterfowl nesting habitat needed to support reproduction in summer; however, in the lower Mississippi Alluvial Valley, the most important supporting service for waterfowl is the production of food resources needed to support overwintering adults (Faulkner and others, 2011). Waterfowl modules of an ecosystem model would likely be very different between these two regions. Other ecological factors will differ among regions. Frozen soils during winter have a major effect on wetland hydrology in northern regions such as the PPR, whereas in other regions frozen soils do not need to be considered. Amphibian habitat models in species-poor areas such as the PPR would differ from models in amphibian-rich hotspots, such as the Mid-Atlantic States (Mitchell, in press). Quantifying floodwater storage in the PPR is based on a spill-point elevation, whereas in the High Plains it is based on hydric-soil delineations. Although a challenge to model development, this diversity of ecological variables is an integral aspect of how wetland ecosystem services are provisioned across different geographic regions. Thus, although the ILM was originally envisioned as a modeling system that would quantify services

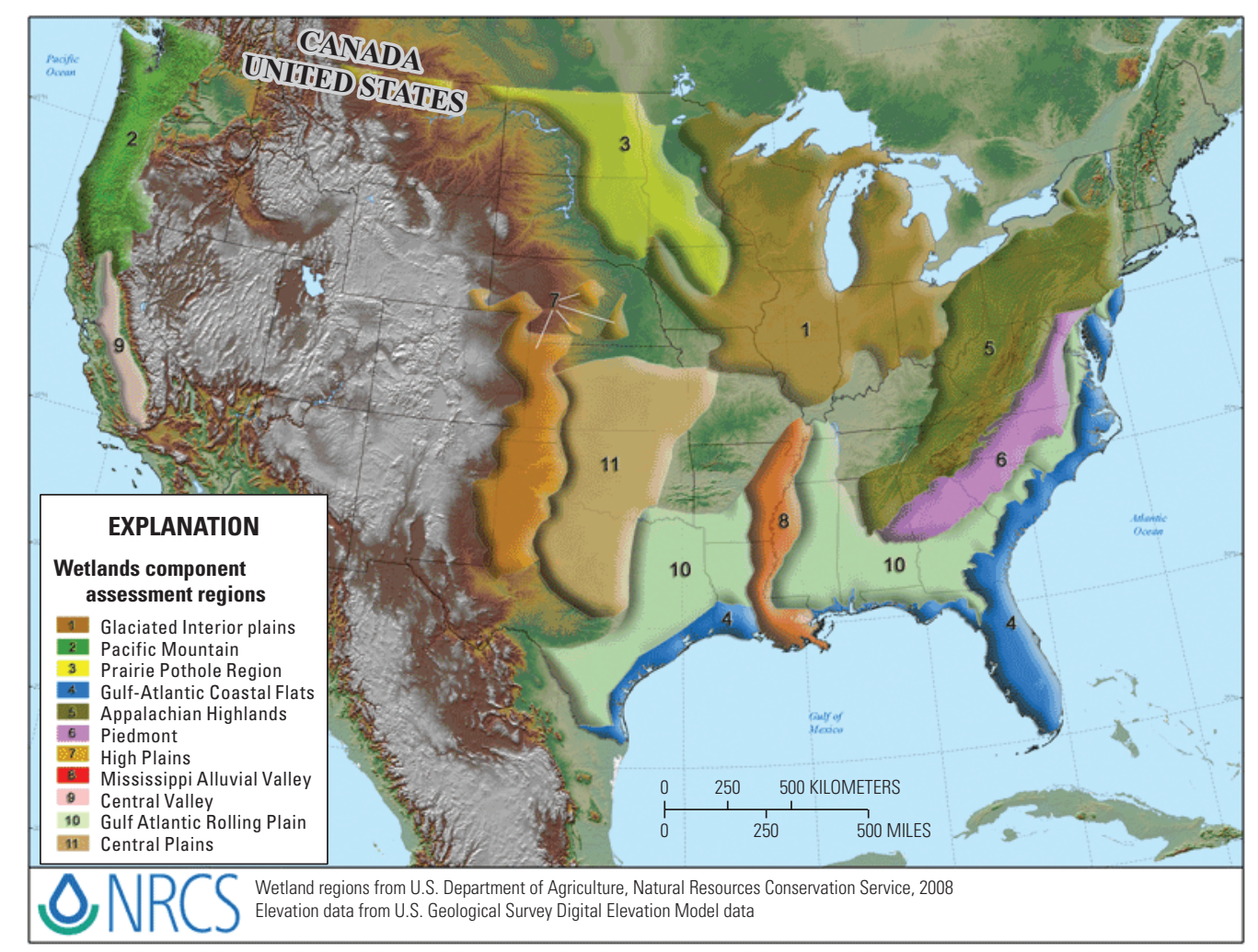


across all physiographic regions of interest, it has, out of necessity, focused on the PPR for initial model development. In the future, the partnership hopes to expand the effort to encompass other regions as data availability and knowledge increases relative to how systems function uniquely among regions. The following sections describe the results of initial modeling efforts for selected ecosystem services using the INVEST and APEX tools.

\section{INVEST Modeling}

The ILM partnership is utilizing the INVEST modeling framework to quantify services provided by wetlands and surrounding ecosystems. One advantage of the INVEST system is the ability to inform the model with expert knowledge when quantitative information is lacking, which has been an asset in augmenting the data collected by the CEAP-Wetlands regional assessments. To date, the ILM partnership's INVEST modeling effort has been able to quantify carbon stores, pollination services, and multiple plant and wildlife habitat services (for example, Mushet and others, 2014) provided by PPR ecosystems under various land-use and conservation scenarios.

\section{Amphibian Habitat}

Provision of habitat for sensitive wildlife species is an important ecosystem service provided by wetlands in the PPR and elsewhere. Initial tests of the INVEST model from 2007 to 2012 focused on quantifying amphibian habitats under various scenarios of conversion of CRP grasslands to croplands. Because their life cycles depend on both wetland and terrestrial habitats, amphibians are a prime example of the view of the ILM partnership that aquatic and terrestrial ecosystems are inextricably linked. Thus, the relevant surveys under CEAPWetlands and other programs have sampled inclusively from the wetland center to the surrounding upland divides that separate wetland catchments (Gleason and others, 2008). INVEST modeling for amphibian habitat involves quantifying habitats and assessing threats to those habitats to derive an overall rating of amphibian habitat quantity and quality. Results from the amphibian habitat modeling scenarios have been published in Mushet and others (2014). Values used to populate the INVEST threat and susceptibility tables are presented in appendix 2, and detailed notes on developing land-cover layers used in our analyses can be accessed in the online supplemental materials for Mushet and others (2014).

The amphibian habitat model demonstrated the utility of the INVEST system to quantify ecosystem services across large regions of the landscape. We divided the PPR into four ecoregions (Northern Glaciated Plains, Northwestern Glaciated Plains, Lake Agassiz Plain, and Des Moines Lobe) following Omernik (1987), which allowed changes in amphibian habitat to be evaluated on an ecoregion-specific basis or across the entire area modeled (table 1). Land-cover maps developed to simulate land-cover changes representative of varying percentages of CRP grasslands being converted back to croplands (for example, corn, soybeans) were used for model runs. The scenario layers created represented current (2012) conditions and conversion scenarios of 10,25, 50,75, and 100 percent. By running a 100-percent conversion scenario, the overall effects of a particular program or practice, in this case the CRP, can be evaluated. For example, 26 percent of the amphibian habitat availability on the PPR landscape in 2012 was determined to be a direct result of CRP grasslands under the 100-percent conversion scenario (table 1). An alternative way of expressing model results is that the conversion of all CRP grassland back to crop production in the modeled region would result in the loss of approximately 2.2 million hectares (ha) of potential habitat suitable for amphibians.

One of the key features of the INVEST model is the ability to produce maps that provide a visualization of how ecosystem services are distributed across a landscape (for example, fig. 2). Visualization aids in efforts to communicate the benefits of conservation programs and practices to a wider audience, including partners, managers, policy makers, and other interested parties.

Table 1. Area (hectare) of amphibian habitat in the Prairie Pothole region of the United States (excluding Montana) with a habitat quality rating greater than or equal to 0.8 under scenarios representing the conversion of various percentages of Conservation Reserve Program (CRP) grasslands to croplands. All losses are relative to amphibian habitat available in 2012.

[From Mushet and others (2014). NGP, Northern Glaciated Plains; NWGP, Northwestern Glaciated Plains; LAP, Lake Agassiz Plain; DML, Des Moines Lobe; $\%$, percent; CRP, Conservation Reserve Program]

\begin{tabular}{cccccc}
\hline \multirow{2}{*}{ Scenario } & \multicolumn{5}{c}{ Amphibian habitat in hectares (percent loss) } \\
\cline { 2 - 5 } & NGP & NWGP & LAP & DML & Total \\
\hline Baseline (2012) & $1,103,000$ & $1,300,000$ & 451,000 & 88,000 & $2,942,000$ \\
$-10 \%$ CRP & $1,053,000(-5 \%)$ & $1,265,000(-3 \%)$ & $436,000(-3 \%)$ & $85,000(-3 \%)$ & $2,840,000(-3 \%)$ \\
$-25 \%$ CRP & $974,000(-12 \%)$ & $1,216,000(-6 \%)$ & $415,000(-8 \%)$ & $81,000(-8 \%)$ & $2,687,000(-9 \%)$ \\
$-50 \%$ CRP & $871,000(-21 \%)$ & $1,136,000(-13 \%)$ & $383,000(-15 \%)$ & $77,000(-12 \%)$ & $2,468,000(-16 \%)$ \\
$-75 \%$ CRP & $800,000(-27 \%)$ & $1,077,000(-17 \%)$ & $361,000(-20 \%)$ & $73,000(-17 \%)$ & $2,311,000(-21 \%)$ \\
$-100 \%$ CRP & $751,000(-32 \%)$ & $1,030,000(-21 \%)$ & $339,000(-25 \%)$ & $70,000(-20 \%)$ & $2,190,000(-26 \%)$ \\
\hline
\end{tabular}



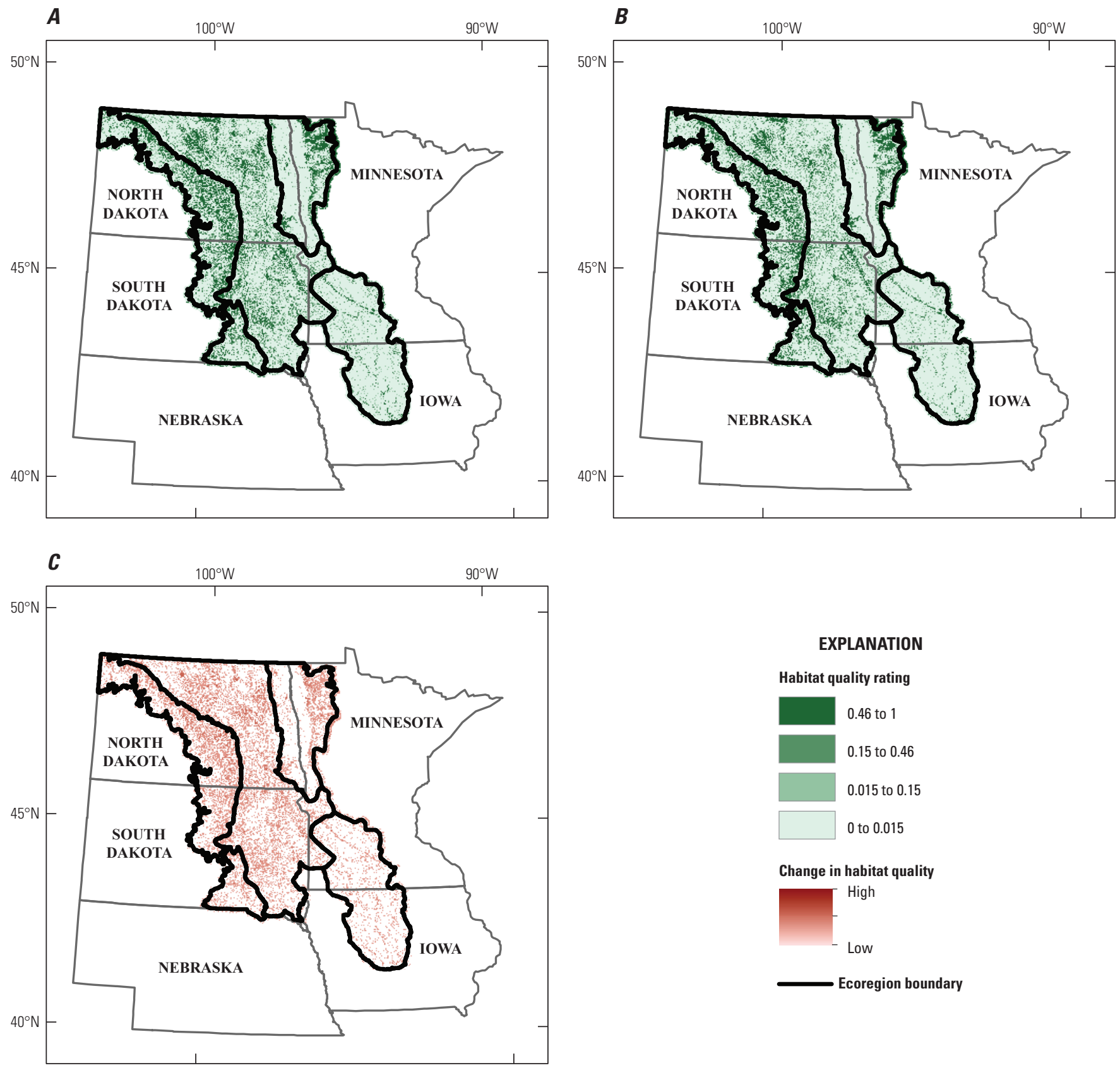

\section{EXPLANATION}

Habitat quality rating

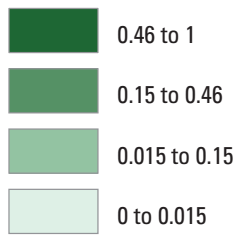

Change in habitat quality

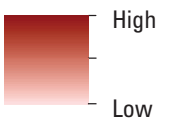

Base from U.S. Geological Survey digital data, 2005, 1:1,000,000

Albers Equal-Area Conic projection

Standard parallels $29^{\circ} 30^{\prime}$ and $45^{\circ} 30^{\prime} \mathrm{N}$

Central meridian $96^{\circ} 00^{\prime} \mathrm{W}$

Ecoregion boundaries from Omernik, 1987

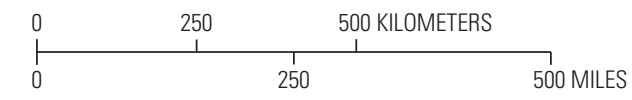

Figure 2. Amphibian habitat quality of the Prairie Pothole Region of the United States under A, current (2012) Conservation Reserve Program (CRP) enrollment conditions; $B$, a scenario in which 100 percent of CRP grasslands are converted to cropland (modified from Mushet and others, 2014); and $C$, difference between 2012 conditions and 100 percent CRP conversion scenario. 


\section{Carbon Storage}

The addition or removal of greenhouse gases such as carbon dioxide $\left(\mathrm{CO}_{2}\right)$ from the atmosphere is a regulating service provided by ecosystems, with resultant effects on the Earth's climate. Ecosystems store carbon in four primary pools: (1) aboveground living biomass, (2) aboveground dead biomass, (3) belowground living biomass (that is, living root systems) and (4) soil organic matter. When carbon in any of these pools is released, it primarily enters the atmosphere as $\mathrm{CO}_{2}$. Thus, by tracking carbon pools, $\mathrm{CO}_{2}$ sequestration or exportation to the atmosphere can be quantified. The INVEST model quantifies carbon stores in each of the primary pools (Natural Capital Project, 2015). We used data from the PPR regional assessment (Gleason and others, 2008) to parameterize the INVEST carbon-storage model for each of the four ecoregions (that is, Northern Glaciated Plains, Northwestern Glaciated Plains, Lake Agassiz Plain, and Des Moines Lobe) of the PPR. The PPR regional assessment revealed that carbon stores in various pools and land-cover types differed among ecoregions (Gleason and others, 2008), so each region was parameterized separately (appendix 3). Aboveground biomass for all crop types was set to zero because they generally recycle carbon too quickly to be a source of long-term storage. Data from Gleason and others (2008) were insufficient to provide accurate carbon pool estimates by land-cover type for the Lake Agassiz Plain and Des Moines Lobe ecoregions; therefore, carbon pools estimates from the Northern Glaciated Plains were used as surrogates for these regions in our model runs.

Land-cover maps for the effects of CRP conversion scenarios on carbon stores were developed following the same procedures used for amphibian habitat runs with one modification: for carbon modeling, wetlands embedded within grassland were uniquely identified so that a different carbon pool estimate could be assigned to these wetlands (see cover code 600 "Wetland within Grassland" in appendix 3). Results from the INVEST carbon model runs are provided in table 2, indicating a potential loss of over 11 million megagrams
$(\mathrm{Mg})$ of carbon storage across the PPR under the 100-percent conversion scenario. Although use of the model was tested under CRP loss scenarios, other scenarios representing various conservation programs and practices can be run if appropriate land-cover maps are available and quantifications of carbon pools are available by program or practice type. As with amphibian habitat, the INVEST modeling system provides a visualization of carbon storage changes under each modeled scenario (fig. 3).

The value of sequestering a ton of carbon in any of the aboveground or belowground pools is equal to the social damage that is avoided by keeping that carbon from being released to the atmosphere. Since societal costs of releasing carbon to the atmosphere are generally quantified in terms of $\mathrm{CO}_{2}$, we converted carbon losses to megagrams of $\mathrm{CO}_{2}$ released (table 3). When carbon is released into the atmosphere as $\mathrm{CO}_{2}$, two oxygen atoms are added to the carbon atom thereby increasing its molecular weight. Thus, for every gram of carbon released, 3.66 grams of $\mathrm{CO}_{2}$ results. Using the central value of estimated societal costs of carbon releases (that is, $\$ 43.00$ per megagram of $\mathrm{CO}_{2}$ ) provided by the U.S. Government Working Group on the Social Costs of $\mathrm{CO}_{2}$ (2013), damages associated with carbon losses to the atmosphere under each CRP loss scenario were monetized (table 4). If all CRP in the U.S. portion of the PPR is converted to crop production, societal costs in excess of 1.8 billion U.S. dollars will be realized.

\section{Plant Communities}

Maintaining the ecological integrity of native plant communities is an important component of maintaining diversity and habitat quality in the PPR. To quantify plant-community integrity, the PPR CEAP-Wetlands Regional Assessment quantified differences in native and nonnative species richness and floristic quality (using a floristic quality index; Swink and Wilhelm, 1994) of plant species among differing land-use treatments (Gleason and others, 2008). The floristic quality index (a measure of similarity to the composition of native

Table 2. Results of Integrated Valuation of Ecosystem Services and Tradeoffs (INVEST) carbon model runs for the Prairie Pothole region of the United States (excluding Montana) under scenarios representing the conversion of various percentages of Conservation Reserve Program (CRP) grasslands to croplands. All losses are relative to estimated carbon stores in 2011.

[NGP, Northern Glaciated Plains; NWGP, Northwestern Glaciated Plains; LAP, Lake Agassiz Plain; DML, Des Moines Lobe; \%, percent; CRP, Conservation Reserve Program]

\begin{tabular}{crrrrr}
\hline \multirow{2}{*}{ Scenario } & \multicolumn{5}{c}{ Change in carbon stores (milligrams) } \\
\cline { 2 - 6 } & \multicolumn{1}{c}{ NGP } & NWGP & \multicolumn{1}{c}{ LAP } & DML & 0 \\
\hline Baseline (2011) & 0 & 0 & 0 & $-107,000$ & $-1,169,000$ \\
$-10 \%$ CRP & $-604,000$ & $-267,000$ & $-190,000$ & $-276,000$ & $-2,926,000$ \\
$-25 \%$ CRP & $-1,531,000$ & $-681,000$ & $-438,000$ & $-549,000$ & $-5,814,000$ \\
$-50 \%$ CRP & $-3,058,000$ & $-1,347,000$ & $-1,313,000$ & $-821,000$ & $-8,637,000$ \\
$-75 \%$ CRP & $-4,563,000$ & $-1,941,000$ & $-1,765,000$ & $-1,104,000$ & $-11,576,000$ \\
$-100 \%$ CRP & $-6,041,000$ & $-2,666,000$ & & & \\
\hline
\end{tabular}



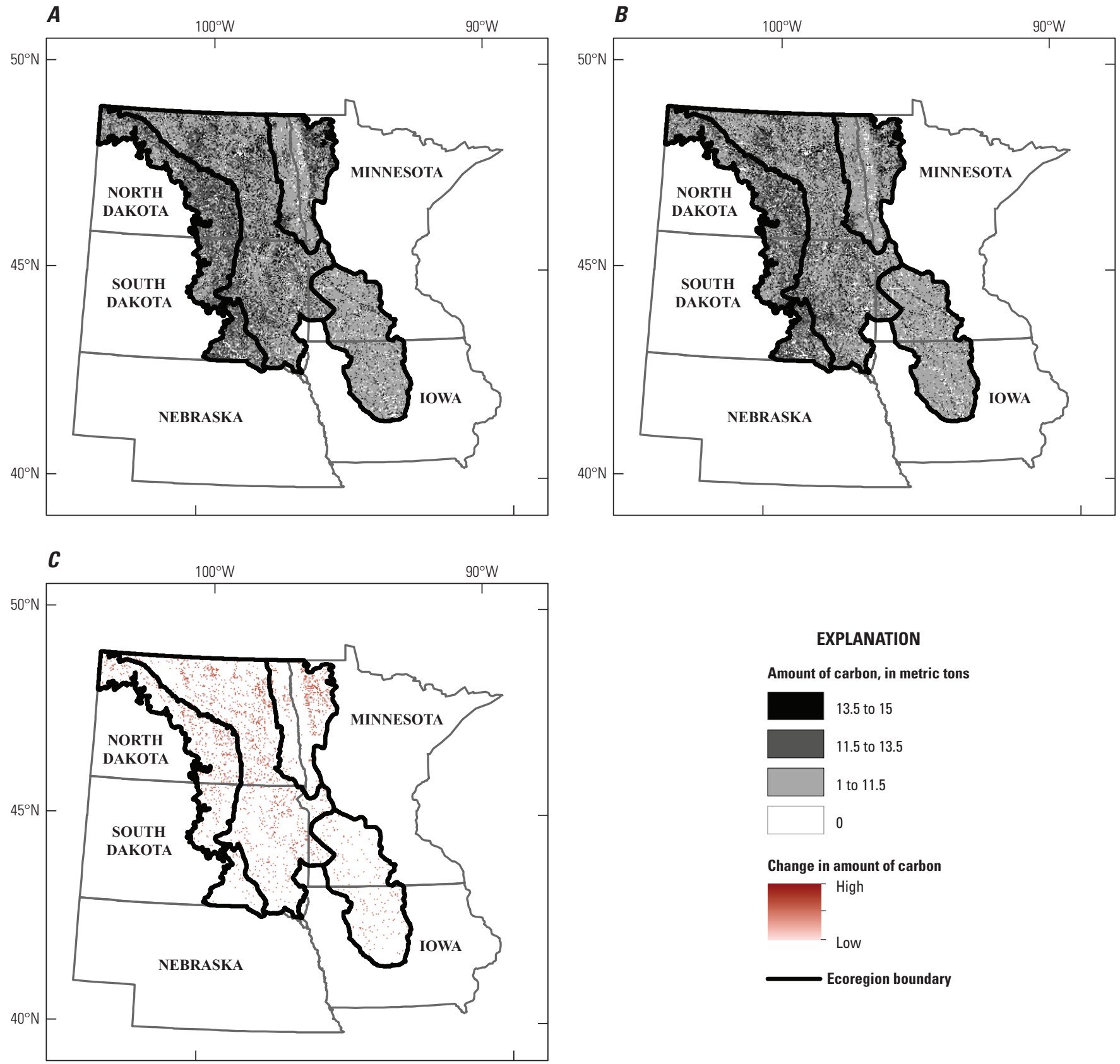

\section{EXPLANATION}

Amount of carbon, in metric tons

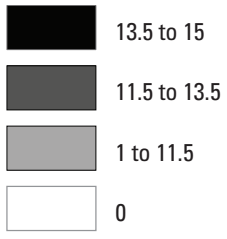

Change in amount of carbon

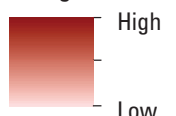

Low

Ecoregion boundary

Base from U.S. Geological Survey digital data, 2005, 1:1,000,000

Albers Equal-Area Conic projection

Standard parallels $29^{\circ} 30^{\prime}$ and $45^{\circ} 30^{\prime} \mathrm{N}$

Central meridian $96^{\circ} 00^{\prime} \mathrm{W}$
Ecoregion boundaries from Omernik, 1987

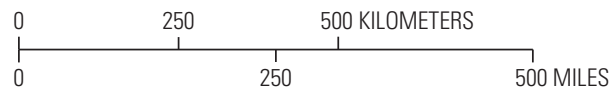

Figure 3. Carbon stores of the Prairie Pothole Region of the United States under $A$, current (2012) Conservation Reserve Program (CRP) enrollment conditions; $B$, a scenario in which 100 percent of CRP grasslands are converted to cropland; and $C$, difference between 2012 conditions and 100 percent CRP conversion scenario. 
Table 3. Carbon dioxide released into the atmosphere (megagrams) under scenarios representing the conversion of various percentages of Conservation Reserve Program (CRP) grasslands to croplands. All losses are relative to carbon stores in 2011.

[NGP, Northern Glaciated Plains; NWGP, Northwestern Glaciated Plains; LAP, Lake Agassiz Plain; DML, Des Moines Lobe; \%, percent; CRP, Conservation Reserve Program]

\begin{tabular}{crrrrr}
\hline \multirow{2}{*}{ Scenario } & \multicolumn{5}{c}{ Carbon dioxide released to atmosphere (megagrams) } \\
\cline { 2 - 5 } & \multicolumn{1}{c}{ NGP } & NWGP & \multicolumn{1}{c}{ LAP } & \multicolumn{1}{c}{ DML } & \multicolumn{1}{c}{ Total } \\
\hline$-10 \%$ CRP & $2,215,000$ & 978,000 & 697,000 & 393,000 & $4,282,000$ \\
$-25 \%$ CRP & $5,609,000$ & $2,495,000$ & $1,605,000$ & $1,011,000$ & $10,720,000$ \\
$-50 \%$ CRP & $11,205,000$ & $4,935,000$ & $3,153,000$ & $2,011,000$ & $21,303,000$ \\
$-75 \%$ CRP & $16,719,000$ & $7,113,000$ & $4,810,000$ & $3,007,000$ & $31,649,000$ \\
$-100 \%$ CRP & $22,136,000$ & $9,769,000$ & $6,467,000$ & $4,045,000$ & $42,417,000$ \\
\hline
\end{tabular}

Table 4. Societal costs of increased levels of atmospheric carbon dioxide due to carbon releases in the Prairie Pothole Region of the United States under scenarios representing the conversion of various percentages of Conservation Reserve Program (CRP) grasslands to croplands.

[NGP, Northern Glaciated Plains; NWGP, Northwestern Glaciated Plains; LAP, Lake Agassiz Plain; DML, Des Moines Lobe; \%, percent; CRP, Conservation Reserve Program. Estimates are based on a societal cost of carbon dioxide of $\$ 43$ (in 2007 dollars) per megagrams (U.S. Government Working Group on the Social Costs of $\left.\left.\mathrm{CO}_{2}, 2013\right)\right]$

\begin{tabular}{cccccr}
\hline \multirow{2}{*}{ Scenario } & \multicolumn{5}{c}{ Societal costs of carbon dioxide released (in 2007 dollars) } \\
\cline { 2 - 6 } & NGP & NWGP & LAP & DML & Total \\
\hline$-10 \%$ CRP & $\$ 95,242,000$ & $\$ 42,056,000$ & $\$ 29,951,000$ & $\$ 16,884,000$ & $\$ 184,133,000$ \\
$-25 \%$ CRP & $\$ 241,166,000$ & $\$ 107,299,000$ & $\$ 69,005,000$ & $\$ 43,479,000$ & $\$ 460,950,000$ \\
$-50 \%$ CRP & $\$ 481,804,000$ & $\$ 212,210,000$ & $\$ 135,558,000$ & $\$ 86,470,000$ & $\$ 916,043,000$ \\
$-75 \%$ CRP & $\$ 718,926,000$ & $\$ 305,866,000$ & $\$ 206,809,000$ & $\$ 129,315,000$ & $\$ 1,360,917,000$ \\
$-100 \%$ CRP & $\$ 951,864,000$ & $\$ 420,049,000$ & $\$ 278,067,000$ & $\$ 173,956,000$ & $\$ 1,823,936,000$ \\
\hline
\end{tabular}

plant communities) provided the best separation of community composition by land use (Gleason and others, 2008). Therefore, this variable was used as the basis for the INVEST plantcommunity quality model, where floral quality index values greater than $(>) 0.5$ (on a scale of 0 to 1 ) represent adequate to good resemblance to native communities and lower values indicate greater presence of nonnative or atypical plant species. We used the same CRP grassland conversion scenarios (that is, baseline of 2012, 10-percent conversion, 25-percent conversion, 50-percent conversion, 75-percent conversion, and 100-percent conversion) in our model runs of plant-community quality. Values used to populate INVEST threat and susceptibility tables are provided in appendix 4. Land-cover layers were the same as those used in the amphibian habitat model. One difference between the INVEST plant-community modeling and the quantifications of other services is that the available plant-community data do not extend past the wetland edge into the upland. Thus, the variable measured is floristic quality of the wetland community rather than the overall plant community of a region. Results of our plant-community model runs are provided in table 5 and figure 4 . In all cases, floristic quality of wetland plant communities declines under scenarios of decreasing CRP on the PPR landscape.

\section{Pollination Services}

Managed honeybee (Apis mellifera) colonies are ubiquitous across most of the United States and provide crop-pollination services valued in excess of $\$ 15$ billion U.S. dollars annually (Calderone, 2012). The INVEST pollination model focuses on native pollinator species, but the ILM partnership wanted the capability to quantify pollination services as related to the vitally important nonnative honeybees. In the PPR, honeybee colonies are placed on the landscape in early spring. Throughout the spring, summer, and fall they pollinate crops and produce honey that is harvested and sold as a commodity. Most importantly, this spring to fall period is when honeybee colony strength and health is built, maintained, and in some cases lost. Following the honey production season, most bee colonies are shipped to warmer regions (for example, in California, Florida, Texas) where they pollinate crops including almonds and oranges. It is essential that the honeybee colonies be healthy enough to survive transport across the United States; thus, building colony strength and health is important during the spring to fall honey-production season. Quantifying the ability of a region to support honeybees in terms of enhancing colony strength and improving 
The Integrated Landscape Modeling Partnership—Current Status and Future Directions

Table 5. Wetland area in the Prairie Pothole region of the United States (excluding Montana) with native plant-community floristic quality ratings greater than 0.5 ( 0 to 1 scale, with 1 being greatest floristic quality). Model run outputs are for scenarios representing the conversion of various percentages of Conservation Reserve Program (CRP) grassland to cropland. All losses are relative to 2012 quality ratings.

[NGP, Northern Glaciated Plains; NWGP, Northwestern Glaciated Plains; LAP, Lake Agassiz Plain; DML, Des Moines Lobe; \%, percent; CRP, Conservation Reserve Program]

\begin{tabular}{crcccc}
\hline \multirow{2}{*}{ Scenario } & \multicolumn{5}{c}{ Floristic quality } \\
\cline { 2 - 5 } & NGP & NWGP & LAP & DML & Total \\
\hline Baseline (2012) & $1,010,705$ & 675,987 & 214,343 & 184,786 & $2,085,821$ \\
$-10 \%$ CRP & 996,971 & 667,861 & 210,135 & 183,536 & $2,058,503$ \\
$-25 \%$ CRP & 974,440 & 654,745 & 203,371 & 181,518 & $2,014,074$ \\
$-50 \%$ CRP & 937,157 & 632,736 & 191,886 & 178,192 & $1,939,971$ \\
$-75 \%$ CRP & 900,837 & 610,609 & 181,906 & 174,214 & $1,867,566$ \\
$-100 \%$ CRP & 869,310 & 592,264 & 171,456 & 171,919 & $1,804,949$ \\
\hline
\end{tabular}

honeybee health is highly desirable. Gallant and others (2014) constructed a preliminary model for mapping honeybee landscape suitability; however, to facilitate modeling of managed bee habitat in a manner compatible with INVEST, the ILM partnership teamed with Drs. Eric Lonsdorf and Amélie Davis to develop a managed-bee model for the INVEST platform. Dr. Lonsdorf was one of the original developers of the nativebee pollination model in INVEST (Lonsdorf and others, 2011).

The new INVEST managed-bee model (see appendix 5 for the model's manual) uses several inputs to estimate floral resource suitability. First, a land-cover dataset is input as a raster file. The land-cover-class pixels are given values of 0 to 1 based on estimates of their floral resource quality, where zero represents the least suitable land cover for bees and 1 represents the greatest suitable land cover for bees. This creates a suitability map for floral resources at each pixel. Because bees forage over some distance, the suitability map is then integrated over a foraging radius. The floral resources for the pixels surrounding the center pixel are weighted higher, because they represent easier resources for the bees to obtain, and weights decrease exponentially as the distance from the center pixel increases. The model result is a suitability map (ranging from 0 to 1 ) for managed bees within the source land-cover extent, which can be thought of as a foraging distance-weighted floral quality map.

The model also requires floral resource quality estimates and a kernel distance script. Expert opinions from bee specialists at the USGS were used to determine the suitability of land-cover types with respect to pollen and nectar content for honeybees. The differences in land cover represent the expected availability of floral resources for bees. The suitability tool produces outputs for three seasons (spring, summer, fall) of floral resource suitability, as well as an overall weighted suitability that combines all floral seasons based on user provided weights (appendix 6). These weights are chosen to represent the relative importance of each season for the provision of resources to the managed bees. The suitability values vary seasonally because summer generally provides the most suitable floral resources for managed bees.
To demonstrate the utility of this newly developed module, we used it to quantify managed bee floral quality for the PPR (table 6, fig. 5), using the same land-cover conversion scenarios evaluated in the other INVEST model runs. In the PPR, most CRP program land that is returned to production is planted to corn, soybeans, or a small grain crop. These crop types provide little pollen or nectar that is beneficial to honeybees, so similarly low floral availability values were assigned to these converted CRP lands. One factor that we were unable to account for in our model parameterization was the variable quality of CRP grasslands. Whereas some CRP grasslands are plentiful in forbs of high value to honeybees and other pollinators, others consist almost exclusively of lesser-quality grass species of little value to pollinators. The spatial data currently available are inadequate to reliably identify the quality of various CRP grasslands with respect to pollinators. Thus, these conservation grasslands were assigned a floral availability value in the middle of the spectrum. Unlike most croplands, the nectar and pollen values of grasslands were held constant across all three seasons to reflect the fact that the forb component of grasslands typically consists of a mixture of species with varying seasonal flowering periods, whereas cropland generally consists of monocultures that flower during very specific and limited periods.

\section{Waterfowl and Grassland Bird Habitat}

The PPR supports a myriad of waterfowl and grassland bird species and is important to the maintenance of their populations. The ILM team is currently working to include several bird habitat models in the PPR INVEST models. Given the wetland-centric focus of CEAP-Wetlands, we are initially focusing on two waterfowl species, the gadwall (Anas strepera) and the northern pintail (Anas acuta). They were selected for study because population survey data reveals opposing trends for these two species during the period of record (fig. 6). Gadwalls have responded very positively to 

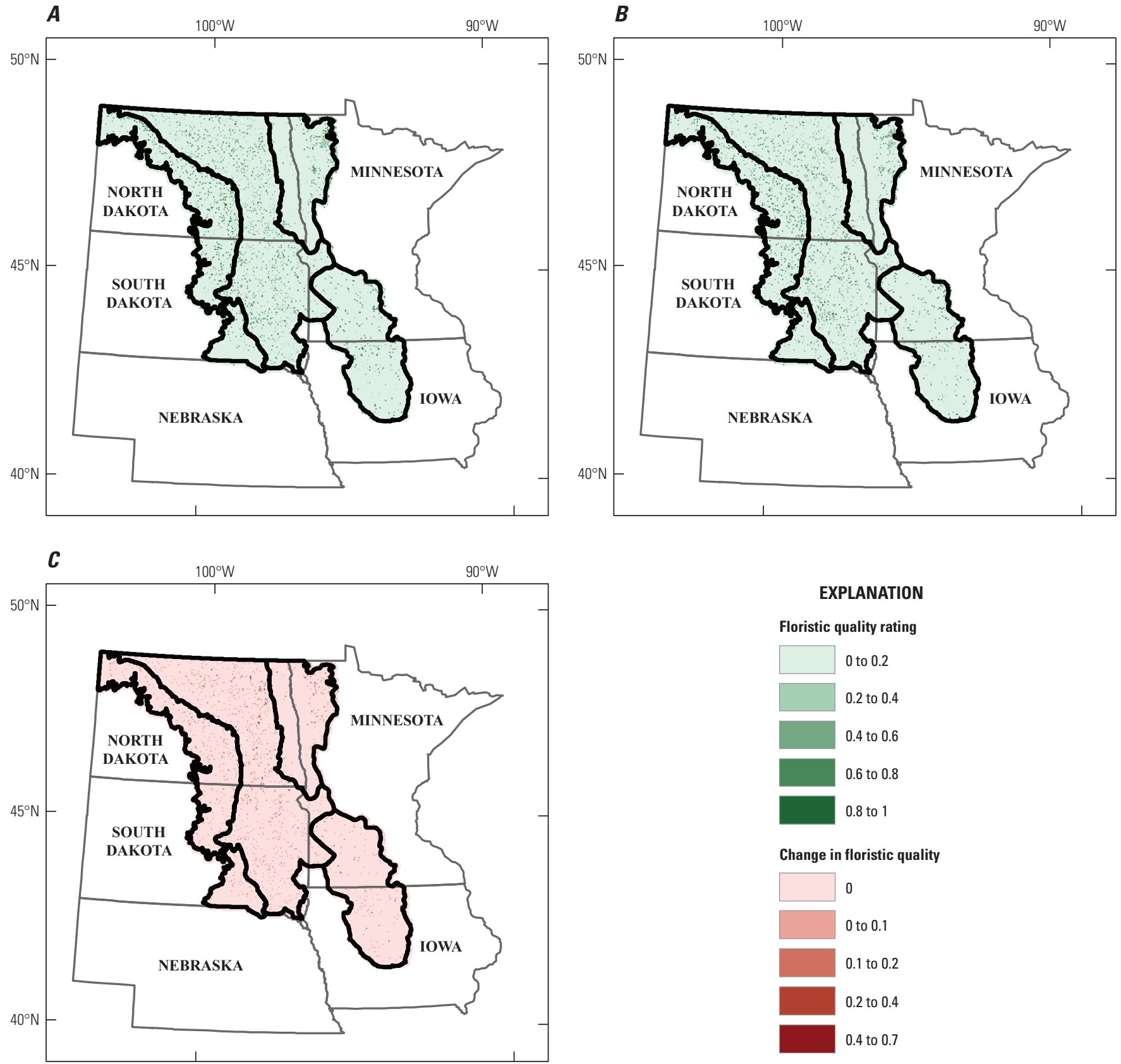

Base from U.S. Geological Survey digital data, 2005, 1:1,000,000

Ecoregion boundaries from Omernik, 1987 Albers Equal-Area Conic projection Standard parallels $29^{\circ} 30^{\prime}$ and $45^{\circ} 30^{\prime} \mathrm{N}$ Central meridian $96^{\circ} 00^{\prime} \mathrm{W}$

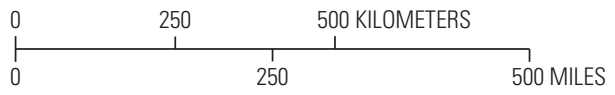

\section{EXPLANATION}

Floristic quality rating

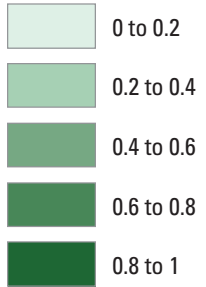

Change in floristic quality

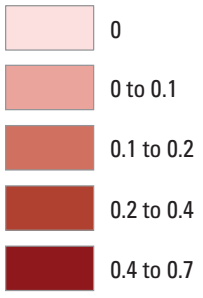

Ecoregion boundary

Figure 4. Native plant floristic quality of prairie pothole wetlands of the United States under $A$, current (2012) Conservation Reserve Program (CRP) enrollment conditions; $B$, a scenario in which 100 percent of CRP grasslands are converted to cropland; and $C$, difference between 2012 conditions and 100 percent CRP conversion scenario. 
Table 6. Area (hectares) of the Prairie Pothole region of the United States (excluding Montana) with a floral resources quality score greater than 0.25 (on a scale of 0 to 1 ) under scenarios representing the conversion of various percentages of Conservation Reserve Program (CRP) grasslands to croplands.

[NGP, Northern Glaciated Plains; NWGP, Northwestern Glaciated Plains; LAP, Lake Agassiz Plain; DML, Des Moines Lobe; \%, percent; CRP, Conservation Reserve Program]

\begin{tabular}{cccccc}
\hline \multirow{2}{*}{ Scenario } & \multicolumn{5}{c}{ Area in hectares with floral resources quality score greater than $\mathbf{0 . 2 5}$ (percent loss) } \\
\cline { 2 - 6 } & NGP & NWGP & LAP & DML & Total \\
\hline Baseline (2012) & $7,485,000$ & $5,076,000$ & $1,870,000$ & 718,000 & $15,148,000$ \\
$-10 \%$ CRP & $7,274,000(-2.8 \%)$ & $4,905,000(-3.4 \%)$ & $1,842,000(-1.5 \%)$ & $710,000(-1.1 \%)$ & $14,730,000(-2.8 \%)$ \\
$-25 \%$ CRP & $6,965,000(-7.0 \%)$ & $4,661,000(-8.2 \%)$ & $1,796,000(-4.0 \%)$ & $700,000(-2.5 \%)$ & $14,121,000(-6.8 \%)$ \\
$-50 \%$ CRP & $6,466,000(-13.6 \%)$ & $4,257,000(-16.1 \%)$ & $1,733,000(-7.3 \%)$ & $682,000(-4.9 \%)$ & $13,138,000(-13.3 \%)$ \\
$-75 \%$ CRP & $6,056,000(-19.1 \%)$ & $3,923,000(-22.7 \%)$ & $1,678,000(-10.3 \%)$ & $666,000(-7.2 \%)$ & $12,323,000(-18.7 \%)$ \\
$-100 \%$ CRP & $5,737,000(-23.4 \%)$ & $3,670,000(-27.7 \%)$ & $1,630,000(-12.3 \%)$ & $651,000(-9.3 \%)$ & $11,688,000(-22.8 \%)$ \\
\hline
\end{tabular}

recent (1993 to 2015) increases in precipitation and water availability across the region, whereas northern pintails have shown marked declines. Both species feed on aquatic invertebrates and underwater aquatic plants in shallow marshes. Gadwalls seek out tall, densely vegetated areas for nesting, and they usually nest within 90 meters (m) of water (Belrose, 1980). Northern pintails use similar wetland habitats for feeding and also nest within $90 \mathrm{~m}$ of water, but they generally select upland nesting areas that are open with short, sparse vegetation, such as cropland stubble before fields are planted in the spring (Belrose, 1980). This tendency to nest in croplands reduces pintail nest success. Including these two species in our INVEST simulations will provide a good contrast between two species with differing nesting-habitat requirements.

To present a holistic view of modeling services across the diverse PPR landscape, we also will be developing a grassland-birds module for the grasshopper sparrow (Ammodramus savannarum). This species is a grassland specialist that breeds in a variety of habitats, from native prairies to human-created grasslands such as CRP fields. Population trends of this species reveal a general decline in numbers across much of the PPR (fig. 7). Key to the maintenance of this species on a landscape is the availability of large, contiguous areas of grassland of intermediate height with moderately deep litter and low shrub density. Specific values of vegetative structure preferred by this species for nesting habitat, patch-size requirements, and other measures of landscape-level requirements will be incorporated into an INVEST model.

\section{Use of InVEST in Other CEAP-Wetlands Regions}

To date, use of the INVEST modeling system has been focused primarily on scenarios run in the PPR; however, a working group was formed to develop a general plant-community conceptual model that could assist in development of
INVEST plant-community models across regions. The conceptual model was recently published in a CEAP Science Note (Conservation Effects Assessment Project, Wetlands Plant Working Group, 2015). The High Plains regional assessment team has explored, to a limited degree, use of INVEST to quantify plant-diversity metrics in playa wetlands. The California Central Valley regional assessments team has used INVEST to model breeding habitats of waterfowl, shorebirds, and upland birds This team is also working to include amphibian habitat quality, carbon storage, and native pollinator habitat quality in their INVEST modeling capabilities.

\section{APEX Modeling}

An important area of research of the ILM partnership involves the use of the Agricultural Policy/Environmental Extender (APEX) model. APEX is a processes-based, field-scale model that facilitates environmental analyses of landscapes and drainage basins. Although APEX provides the water and sediment outputs needed to facilitate quantifications of ecosystem services, it was designed for flowing water (that is, stream) systems without specific capabilities or guidelines for use in depressional wetland systems such as those that dominate the PPR and other parts of the United States (for example, High Plains, portions of the mid-Atlantic, California Central Valley). From 2012 to 2014, the ILM Partnership, led by USGS, initiated work to develop a methodology for adapting APEX to depressional settings where wetlands are not typically connected by well-developed stream networks. Because this is a substantially new extension of the APEX modeling system, a detailed description of model development and progress are provided below. Continued development of the APEX model for use in depressional systems will be led in the future by the CEAP Modeling Team in Temple, Tex. 

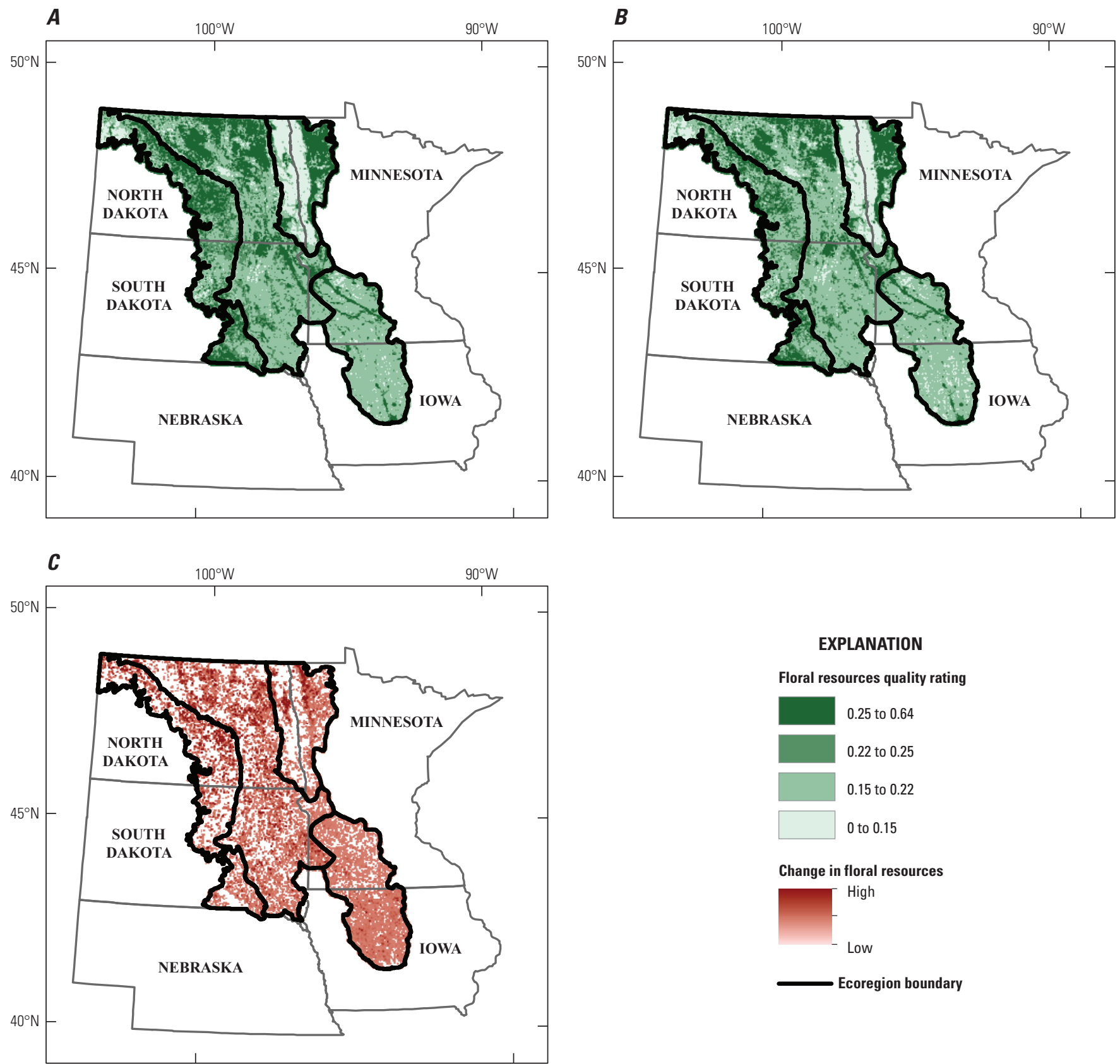

\section{EXPLANATION}

Floral resources quality rating

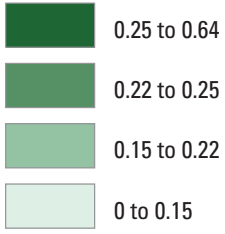

Change in floral resources

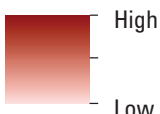

Low

Ecoregion boundary

Base from U.S. Geological Survey digital data, 2005, 1:1,000,000

Albers Equal-Area Conic projection

Standard parallels $29^{\circ} 30^{\prime}$ and $45^{\circ} 30^{\prime} \mathrm{N}$

Central meridian $96^{\circ} 00^{\prime} \mathrm{W}$
Ecoregion boundaries from Omernik, 1987

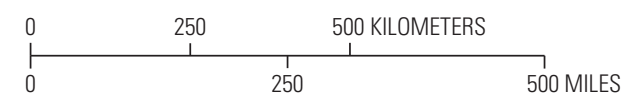

Figure 5. Managed bee floral resources quality of the Prairie Pothole Region of the United States under $A$, current (2012) Conservation Reserve Program (CRP) enrollment conditions; $B$, a scenario in which 100 percent of CRP grasslands are converted to cropland; and $C$, difference between 2012 conditions and 100 percent CRP conversion scenario. 
A. Gadwall (Anas strepera)
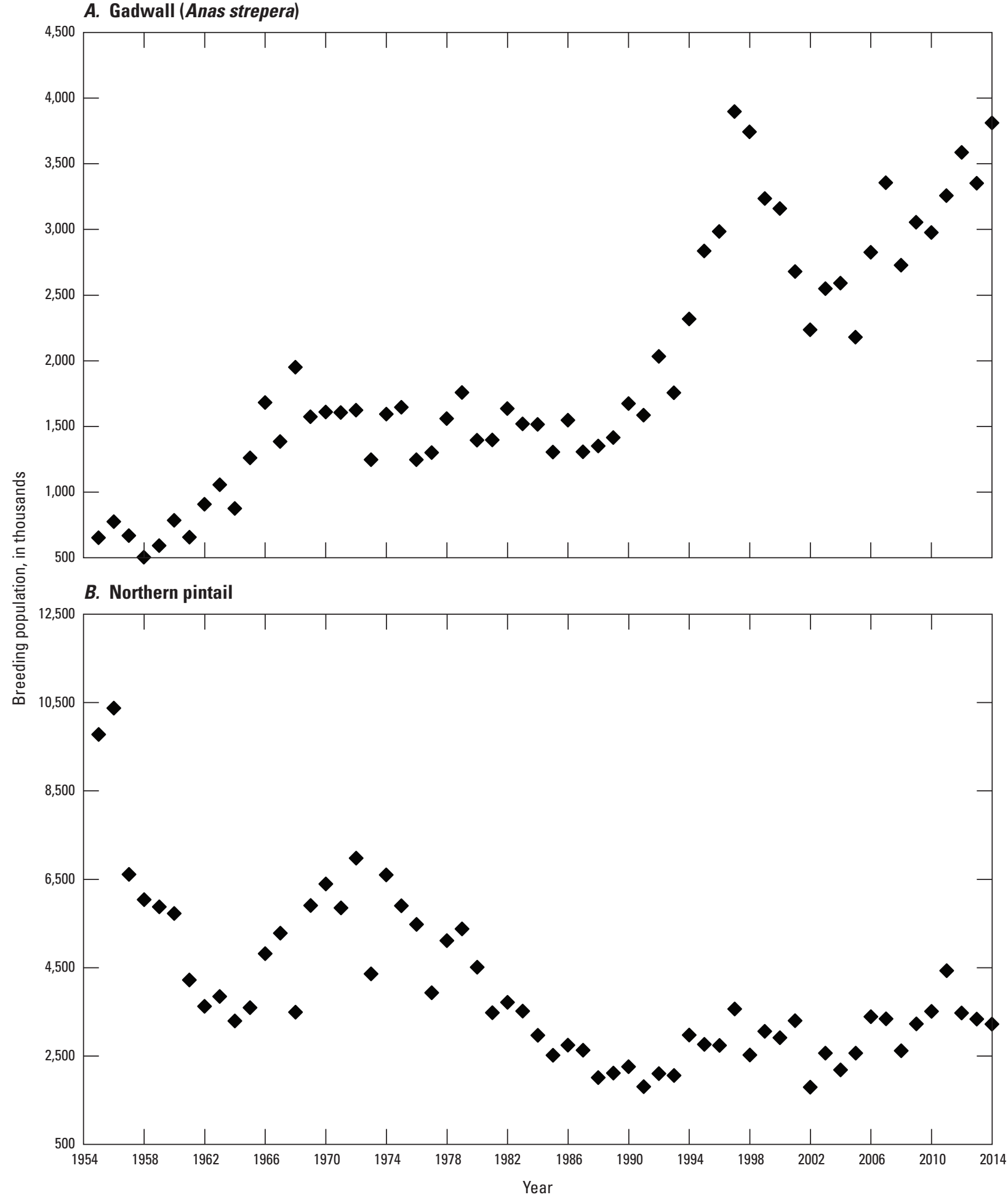

Figure 6. Population trends of $A$, gadwall (Anas strepera) and $B$, northern pintail (Anas acuta), 1955 to 2014 (Zimpfer and others, 2014). 


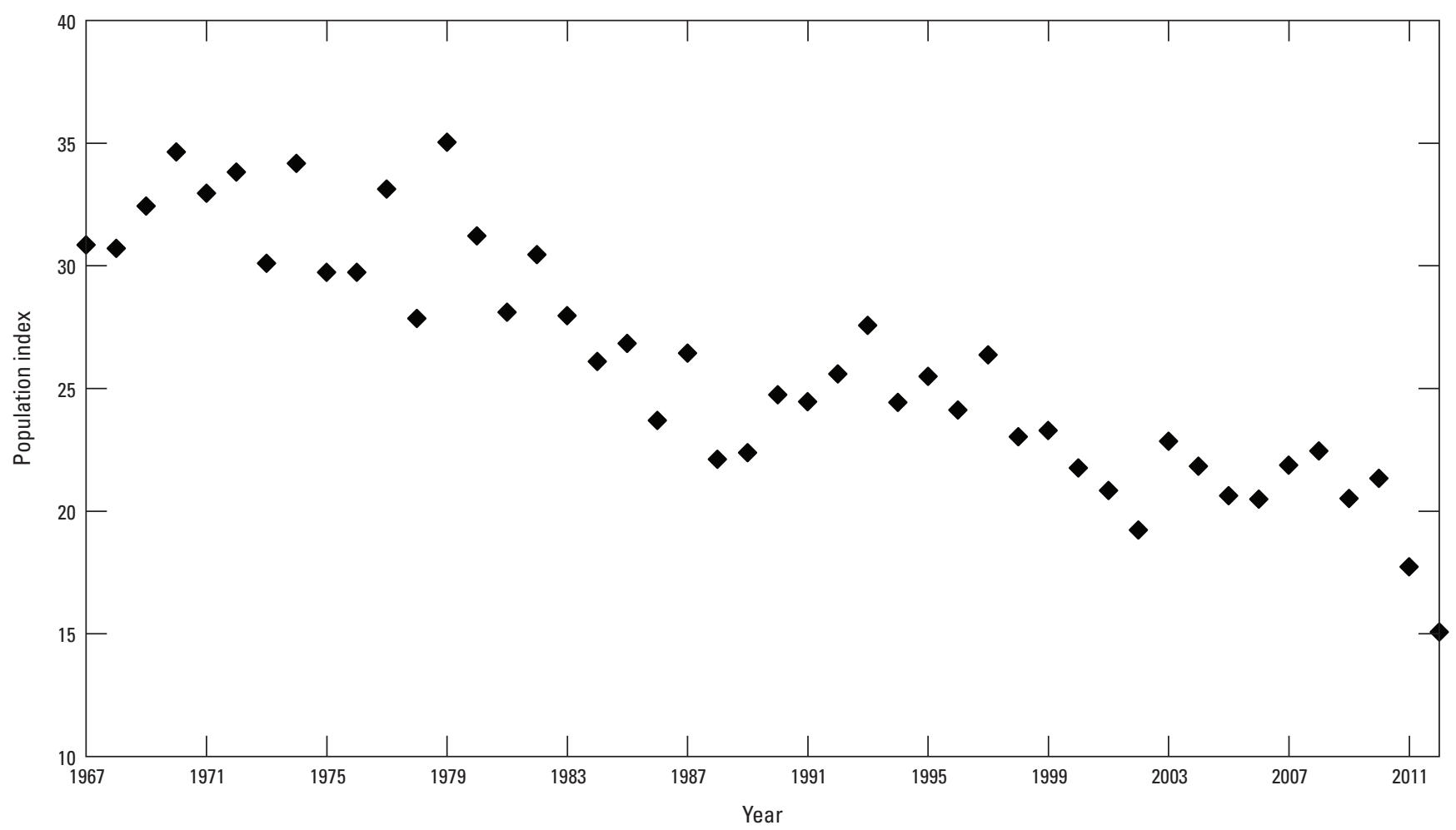

Figure 7. North American breeding bird survey population index for the grasshopper sparrow (Ammodramus savannarum) in the central Mixed-Grass Prairie region, 1967 to 2012 (Sauer and others, 2014).

\section{Overview of Modeling Progress}

The USGS simulated observed changes in water-surface elevations of depressional wetlands at the Cottonwood Lake Study Area (CLSA) from 1982 to 2006. The CLSA has been a wetlands research and monitoring site since its purchase by the U.S. Fish and Wildlife Service in 1962; it also is a USGS wetland ecosystem monitoring site (Winter, 2003). The 25-year simulation period represents years for which needed meteorological data were available for CLSA. Additional data used for the simulation include a high-resolution, light detection and ranging (lidar)-based digital elevation model (DEM) and soils data from the Soils Survey Geographic database (SSURGO; Soil Survey Staff, 2013).

\section{Elevation Data}

The basic elevation data used to describe the study basin for the APEX model was a bare earth DEM with a 0.25 -square-meter $\left(\mathrm{m}^{2}\right)$ cell size. The DEM was based primarily on airborne lidar data acquired by Fugro Horizons of Rapid City, S. Dak., and made into a DEM by USGS personnel using the ArcGIS extension LP360 (QCoherent Software, 2013). Additional DEM processing to incorporate the bathymetry of study wetlands was done using survey-grade global positioning system (GPS) data collected by soundings of the bottom of each wetland. Through these steps, a continuous elevation model representing both the surrounding uplands and wetland basins was produced for the site.

Including the bathymetry of wetlands was essential to this approach. First, it allowed runoff estimates to be translated directly from volume to water depth. Knowing how water depth changes over time is critical to classifying and quantifying ecosystem services that accrue from depressional wetlands. Additionally, water depth can be converted directly to water-surface elevation with a georeferenced DEM, thereby facilitating use of historical water-surface elevation data to calibrate and validate hydrologic models. Finally, bathymetric information makes it possible to know water depths throughout the wetland on a spatially explicit basis, which is fundamental to understanding the distribution and extent of wetland vegetation, as well as depth-dependent physical and chemical processes.

The importance of using a high-resolution DEM for hydrologic modeling is heightened for the depressional wetland basins of the PPR and High Plains because of the low topographical relief in these areas. This low relief diminishes the utility of coarser scale DEMs, such as the standard 10-m or 30-m DEMs, because the aggregation of elevation data into these relatively large raster cells creates ambiguity in analyses, such as defining catchment boundaries. Conversely, finer resolution elevation data, such as those acquired by lidar, represent the land surface more precisely (finer spatial resolution) and 
typically have greater vertical accuracy. These qualities make it possible to use tools in GIS to depict important hydrologic features with greater accuracy, like the position of catchment boundaries. In our approach, considerable importance is placed on representing the topography of the site accurately because this is perhaps the most critical element to the hydrologic simulation of a basin (Wechsler, 2007).

To model the bathymetry of a wetland from individual GPS data points, elevation values were interpolated between the GPS points and the shoreline to build a continuous raster surface. The lidar-based DEM of the shoreline and uplands was incorporated by first converting this part of the elevation model from raster cells to points, which allowed the slope of the land surface to be used in the interpolation. The GIS workflow and settings for this process were developed empirically, exploring different types of interpolation and quantitatively comparing the results of each. Initial efforts employed "kriging," a geostatistical analysis technique available in ArcGIS Desktop. Despite multiple iterations and different settings for parameters, the kriging approach consistently produced undesirable artifacts in the modeled surface, such as repeating ridges and ledges. Still using ArcGIS, the wetland bathymetry was modeled with both "inverse distance weighting" and "radial basis" functions, but the resulting surfaces were not satisfactory. The tool that created the best bathymetric surface from the survey points was "splining." This approach connects the narrow band of points generated from the shoreline, as described above, to the individual GPS points on the wetland bottom to produce a continuous raster surface that minimizes the curvature between points to produce a realistic representation of the basin.

Once wetland bathymetry was successfully interpolated and joined with the DEM of the land surface, much of the remaining GIS work was accomplished using tools that are part of Arc Hydro, an ArcGIS extension that can also be used as a temporal and spatial modeling platform. Our technique exploited only a few of the tools of Arc Hydro, using these tools to condition and analyze the DEM. Nevertheless, the features created in this step were essential and were used either as direct input for the APEX model of this site or as potential future input to APEX. For example, user-specified criteria direct Arc Hydro to generate basin boundaries, which we used in APEX to measure basin and subarea extent, along with corresponding slopes. Arc Hydro can also be used to delineate the location of streams, a feature that we did not use in APEX, but that could be incorporated if needed to improve model performance for other sites.

The first task we undertook to extract this information from the DEM was conditioning it for hydrologic analysis by eliminating sinks, which are those raster cells with a lower elevation than surrounding cells, and which therefore have an undefined flow direction. Flow direction must be defined for the entire DEM because the algorithms Arc Hydro uses to complete subsequent automated steps that produce GIS layers used in APEX rely on each cell having a definite flow direction. Arc Hydro eliminates a sink from the DEM by digitally "filling" the lower elevation cell (or cells) to a level that is higher than at least one of the adjacent cells, thus allowing the flow direction to be determined for the cell. This is a relatively straightforward task to accomplish if water is to be routed through a basin with a typical dendritic stream network because even before sinks are eliminated the DEM intrinsically has a single low point where flow accumulates (that is, the most downstream point in the stream network); however, in landscapes with depressional wetlands there is no single stream network or low point to where water can be routed, but rather there are multiple wetlands in adjacent basins into which water must be directed. This landscape complexity makes the process of eliminating sinks and defining flow direction with an automated technique difficult.

In the detailed guidance for how Arc Hydro can be applied to analyze landscapes with depressional wetlands, such terrain is referred to as "deranged" (Djokic, 2008), which is the geomorphological term for a nondendritic drainage pattern. Although Arc Hydro is powerful for hydrological analysis, it cannot automate the elimination of sinks for such drainage patterns without using pre-existing GIS layers to identify individual wetland basins; these GIS layers are generally not available for the PPR. Nonetheless, being able to automate this task is essential given the substantial number of hydrologic sinks in these areas; for example, in a single DEM representing the 800 ha around CLSA, there were 246,135 sinks. Hence, we sought to increase the functionality of this approach by developing an algorithm and automated GIS workflow that works with Arc Hydro to objectively identify and delineate the lowest elevation point in each wetland basin in a DEM, which are the points Arc Hydro must reference to automatically fill sinks correctly. This was done successfully using ArcGIS Desktop Model Builder.

This model construct (fig. 8) compares the location and elevation of several Arc-Hydro-generated GIS layers to specify the exact raster cell in each wetland basin to which water should flow. Accordingly, the output is a feature class that identifies the lowest elevation cell in each basin. The output is then used to assign each of these cells a value of " 1 " for the "IsSink" field, which prevents these cells from being filled when using the "Fill Sinks" function of Arc Hydro.

On our test DEM of approximately 800 ha, this process automated the identification and hydrologic conditioning of 79 wetland basins. To check these results, basins that our process identified were compared with those in the National Wetlands Inventory (NWI), an extensive wetland database developed by the U.S. Fish and Wildlife Service (2015). This revealed that along with each of the NWI wetlands in these 800 ha that were successfully identified by our automated GIS process, 8 additional wetlands were also delineated. Each of these additional wetlands was verified as being actual wetland using field observations. 


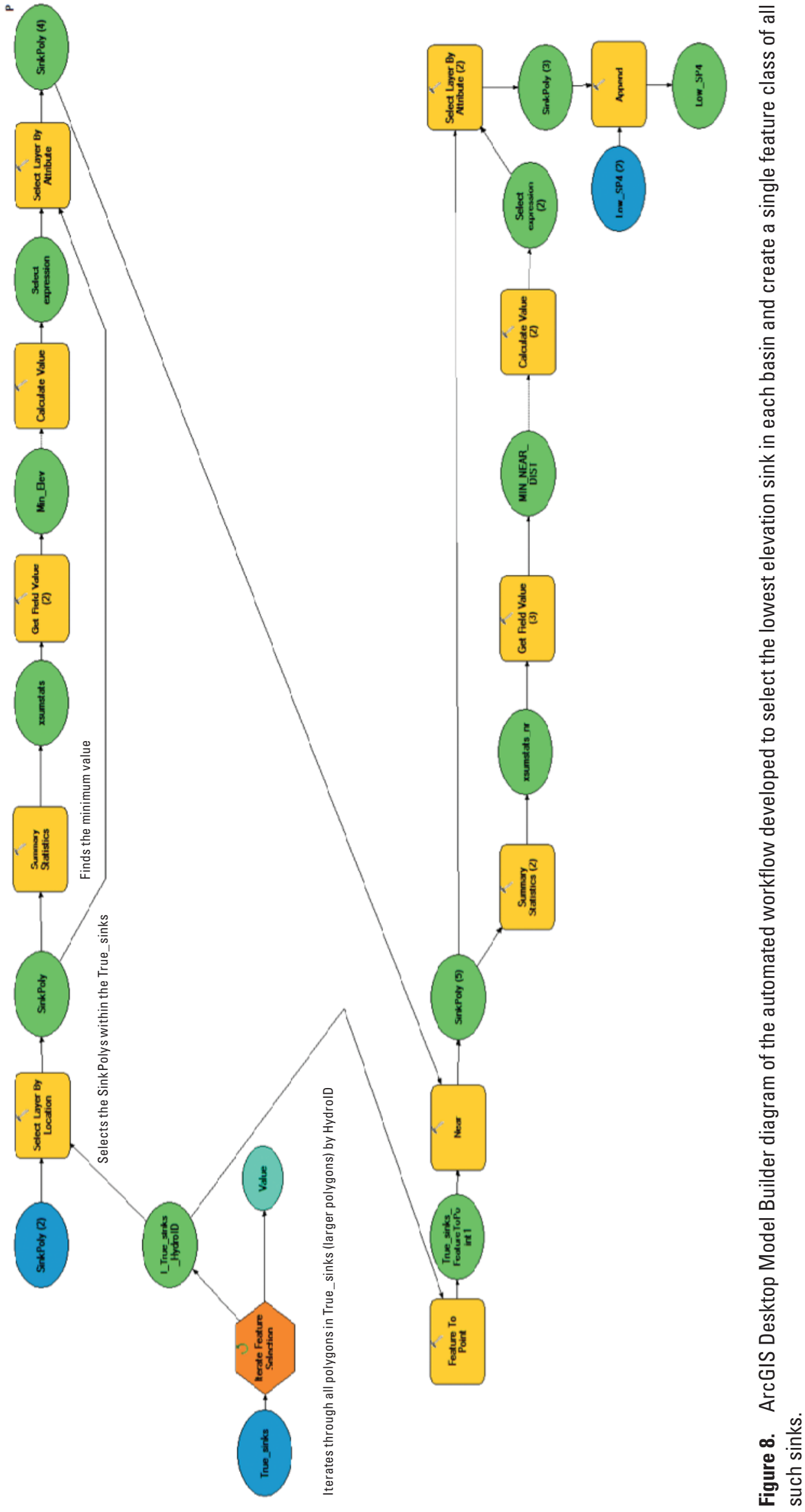




\section{Processing Elevation Data for Input to APEX}

The primary decision we faced in building an APEX model was how to delineate subareas within a basin. There are two basic considerations that needed to be taken into account. First, each subarea should be relatively homogenous with respect to slope, soils, and land cover. Correspondingly, important differences in these same elements across the basin should be recognized by creating unique subareas based on these criteria. The second consideration was how to delineate subareas in a way that would allow the reservoir feature of APEX to best represent the dynamic changes in pool volume, areal extent of inundation, and water-surface elevation of the wetland. For example, if the APEX reservoir feature floods one adjacent subarea during wet periods, then the flood-prone part of the basin should have two subareas (fig. 9A). In addition, wetland basins that can overflow during wet periods need to have subareas built so that water can actually be routed through the overflow spillway to the next downstream basin. This may require, for example, that the subarea with the overflowing reservoir extend to the point on the catchment divide where overflow occurs, which may require an irregularly shaped subarea to maintain within-subarea homogeneity (fig. $9 B$ ).

The subareas created for modeling the basin of wetland $\mathrm{T} 1$, one of 16 wetlands in the CLSA, are shown on a shaded DEM with the water surface visible (fig. 10). The basin boundary was constructed based on the modeled bathymetric surface, which is not shown. The location of subareas was

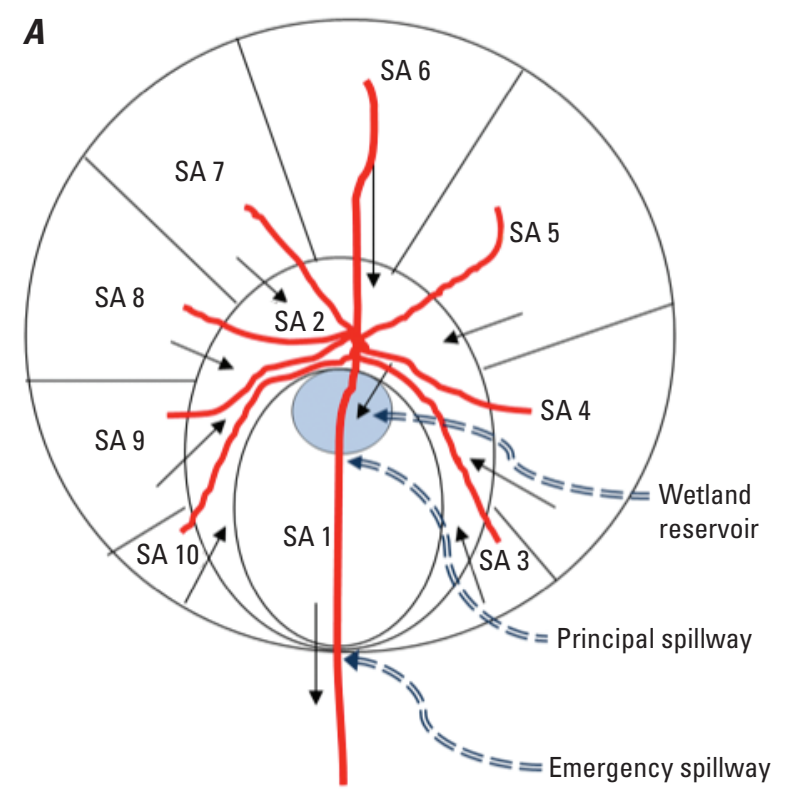

determined based on slope measurements made in a GIS. Once basins and subareas are constructed, these processed elevation data are queried through ArcGIS Desktop functions that reside either in Arc Toolbox or as basic functions in the toolbar. Values extracted from this elevation dataset include area, mean slope, and slope length. These values are stored in a spreadsheet for arithmetic processing, reference, and subsequent input to APEX. Also note in figure 10 that the wetland pool of the basin described, T1, has merged with the pool of the basin immediately to the west, $\mathrm{P} 1$. This is a common occurrence for many wetlands during wet periods and is important to address from both a hydrological modeling perspective, as well as for biological modeling. In drier conditions, as the water surface drops, these same pools separate.

As described previously, high-resolution DEMs are desirable for accuracy and overall utility in modeling the hydrology of low relief landscapes such as the PPR; however, some error is still inherent in using such models (Wechsler, 2007), and one example is the extraction of slope values, which may vary with the grid size of the DEM (Zhang and Montgomery, 1994; Zhang and others, 1999). Moreover, the documentation for APEX does not specifically address the use of DEMs to derive important topographic parameters but rather instructs the user to do an analysis based on elevation contour lines. In this case, the APEX parameter is Average Upland Slope (STP). Hence, to develop a reliable and consistent method to estimate average slope for each subarea, results from three different techniques were compared: (1) the Contour-Length

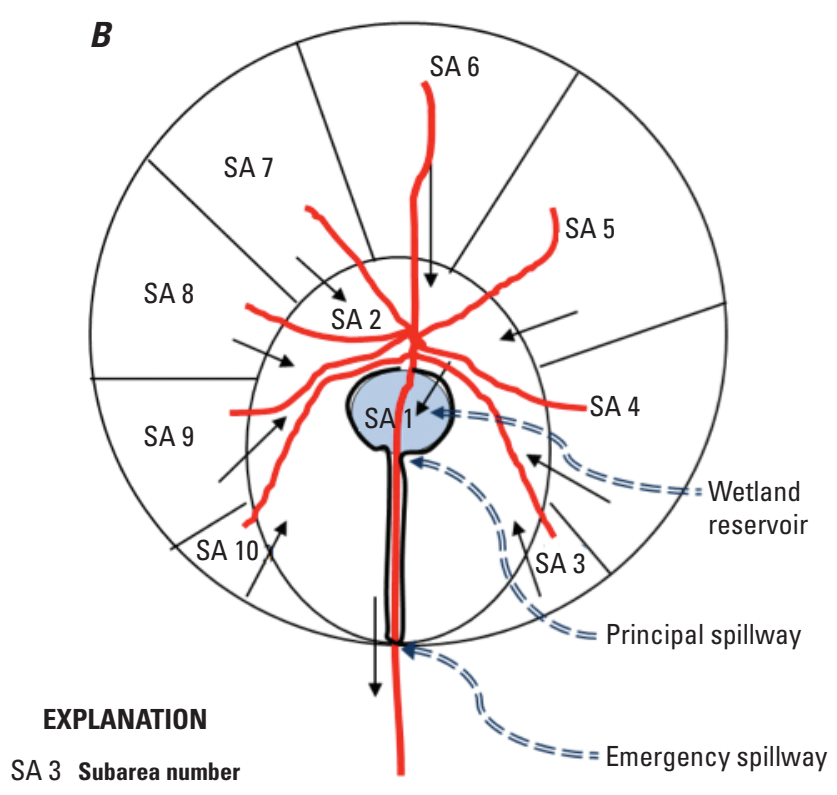

Figure 9. Two schematic diagrams of alternate subarea configurations for a wetland basin in the Agricultural Policy/ Environmental Extender (APEX) model that could flood subareas 1 and 2, and also allow overflow to the adjacent basin. Spillway locations refer to reservoir-related variables of APEX. $A$, a basin with a relatively large subarea 1 where the wetland reservoir is located; and $B$, the same basin with a small subarea 1 that extends to the catchment boundary by way of a narrow strip, which would be suitable if the higher elevation areas that flood are substantially different in slope or soil type than the area immediately surrounding the wetland. 


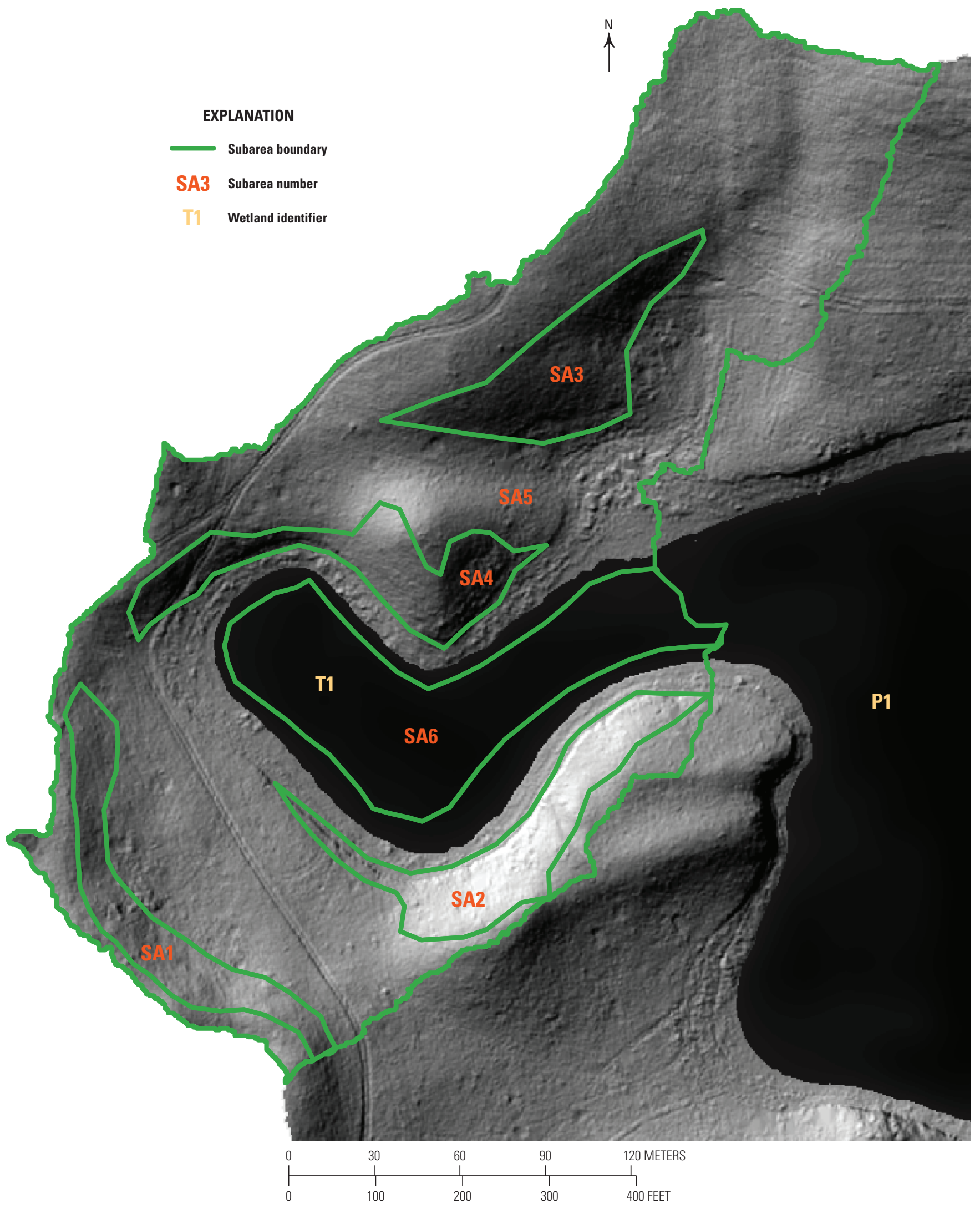

Figure 10. Configuration of the six subareas being used in the Agricultural Policy/Environmental Extender (APEX) model of the basin for wetland T1 (SA1-SA6). 
Method referred to in the APEX User's Manual (Steglich and Williams, 2013) and described by Williams and Berndt (1977), (2) a raster-based analysis of the existing DEM using a zonal statistics analysis of a slope raster, and (3) a rasterbased analysis of the DEM with larger raster cell sizes derived by aggregating the original $0.25-\mathrm{m}^{2}$ cells into $9-\mathrm{m}^{2}$ and $16-\mathrm{m}^{2}$ raster cells followed by a zonal statistics analysis. In all cases, the same $0.25-\mathrm{m}^{2} \mathrm{DEM}$ was the initial data source, and all analyses were done in the ArcGIS environment. Results of the three techniques were comparable for all but the steepest slopes, which occur in subarea 2 . The average slope in subarea 2 was estimated to be 24-25 percent using the zonal statistics techniques but only 19 percent using the ContourLength Method. Our preference was to use zonal statistics on a slope raster made from the original DEM because it provided a more direct workflow and also introduced a minimum amount of data transformation.

A second topographic parameter for APEX input extracted from the DEM was Average Upland Slope Length (SPLG). Values for SPLG were derived by visual inspection of slope aspect values for each subarea to obtain a representative slope length parallel to the predominant slope aspect.

\section{Soils}

Soils data are input to the APEX model primarily through tables in a Microsoft ${ }^{\circledR}$ Access ${ }^{\circledR}$ database. A version of this database specific to the State of North Dakota was provided by the USDA Grassland, Soil and Water Research Laboratory in Temple, Tex., and was the starting point for representing the soils present at the study site. Further modification of this database was then necessary prior to running APEX so that the database associated the proper soil with the county where the study site is located, and so each of these soils had the most recent and comprehensive values available. Guidance for making these modifications was obtained in the form of documentation (Steglich and Francis, 2008) and specific input from individuals at the USDA Grassland, Soil and Water Research Laboratory.

Although the soils mapped to the study site were included in the North Dakota version of the APEX database, not all of these soils were associated in that database with the county where the study site is located, which prevented them from being accessed and used in the WinAPEX interface. To make these soils accessible, the tables SOILS_LIST and SOILS DATA were modified by duplicating existing rows from the same table that show the desired soils and soil layers, and then replacing the value in the Federal Information Processing Standard (FIPS) code field of these new rows with the value that associates the data with the county where the study site is located. The correct FIPS code to use for this was in the table COUNTIES, and once this was updated the desired soil could be viewed and selected when creating or editing subareas in the WinAPEX interface. With respect to which soils were mapped to and identified at the study site, it is worth mentioning that the SSURGO data used for this purpose (Soil Survey Staff, 2013) were resurveyed for North Dakota after this study began. This has resulted in a few soil name changes, an entirely new series of map unit symbols, and an extra level of care being required to assign the correct chemical and physical soil properties to each subarea.

An example of the ongoing refinement of the APEX platform that has informed our application of the model was the use of updated soil parameter values provided to us by the CEAP Modeling Team. These new values for certain parameters replaced the existing ones in the soils data tables with the most recent data available from the NRCS Soil Survey Laboratory in Lincoln, Nebraska.

\section{Climate}

Historical climate data measured at the CLSA were used for this phase of the APEX modeling effort because the intent was to calibrate and validate the model based on observed CLSA water-surface elevations. Parameters measured at CLSA include daily temperature maxima and minima and daily precipitation; however, there were substantial gaps in this record, and missing values were estimated using data from nearby weather stations. For precipitation, a weighted average of the closest weather stations was developed by USGS researchers in Denver to maximize agreement among CLSA values. Missing temperature values were filled with unweighted values directly from the nearby weather stations, so that the record from the station with the best agreement with CLSA values was used first, and any remaining missing values were filled using the record from the station with the second best agreement with CLSA values. The data used to fill missing values for temperature and precipitation were from the National Oceanic and Atmospheric Administration (NOAA; National Oceanic and Atmospheric Administration, 2013) and the North Dakota Agricultural Weather Network (2013).

Measured solar radiation data were not available for the period of this simulation (1982-2006), but we did identify a source of modeled solar radiation data, which was used to compile daily values. This data source is the National Solar Radiation Database (NSRDB; National Solar Radiation Database, 2013; Wilcox, 2007), which has modeled solar radiation from 1961 to 2010. Values are based on the METSTAT model (Maxwell, 1998), which utilizes observed cloud cover data and measured radiation at discrete locations. In using this database for solar radiation data, several different radiation parameters, including direct normal, diffuse horizontal, and global radiation, were assessed. The solar radiation input to APEX used was the sum of direct normal and diffuse horizontal radiation. An additional source of modeled solar radiation data that offers even better agreement with ground measurements is the SUNY model (Perez and others, 2002), but this was not used for this study because the time period covered by the SUNY model is only the latter part of the simulation period. 
Additional climate data for APEX input were provided by the CEAP Modeling Team from a database of time series climate data assembled for individual weather stations throughout the United States. For this simulation, parameter values from this database were accessed for mean daily relative humidity, wind velocity, and solar radiation that correspond to conditions at Pettibone, N. Dak., which was the nearest station to the study site.

\section{Implementing WinAPEX for the Prairie Pothole Region}

For this project, we used WinAPEX0806, version 1.0.0.0, created April 4, 2013. The APEX engine was 0806, created April 22, 2013. We ran WinAPEX in the Windows ${ }^{\circledR} 7$ operating system.

\section{Stream Parameters}

We sought to minimize the effect that in-channel processes have on sediment movement or flow routing in this model because there are no streams at the study site. Hence, the recommendation in the WinAPEX dialog box to set the variables channel length (CHL), depth (CHD), slope (CHS), and roughness (Manning's N; CHN) equal to zero for basins less than 20 hectares (Steglich and Williams, 2013) were followed. To set values for the parameter RCHL (Length of Routing Reach, in kilometers) there are a few rules in the APEX user's manual (Steglich and Williams, 2013) based on (1) the value of the CHL parameter (distance from outlet to most distant point in subarea, in kilometers), which has its own guidance as described above; and (2) whether or not the subarea is EXTREME (does not receive water from another subarea) or DOWNSTREAM (does receive water from another subarea). Specifically, the rules for setting RCHL state that if the subarea being described is EXTREME, then the RCHL value must equal the CHL value, and conversely if the subarea being described is DOWNSTREAM, then the RCHL value cannot equal the CHL value. Accordingly, we set RCHL to 0 for subareas $1,2,3$, and 4 (see fig. 10), whereas for subareas 5 and 6 we left RCHL set to 0.025 kilometer $(\mathrm{km})$, which is the default value. This value seems conservative for subarea 5, which is relatively large, but it should help minimize the effect of in-channel processes related to sediment transport. Given the absence of any streams, it may be useful to reduce this value further.

The parameters RCHC (USLE Crop Management Channel Factor) and RCHK (USLE Erodibility Channel Factor) were set to 0.0001 to prevent the channel from being a sediment source; however, it will be important to discover if sediment eroded from the upland will still be routed to the reservoir with these settings. The parameters RFPW (Buffer/ Floodplain Width, in meters) and RFPL (Buffer/Floodplain Length, in kilometers) were both set to 0 because there was no flood plain; it would be preferable to treat any surface runoff as overland flow throughout the study area. Additional values used for subareas are shown in appendix 7 , and control file values are shown in appendix 8 .

\section{Reservoir Feature}

The inclusion of a functional APEX reservoir is important to successfully model the hydrology of depressional wetland basins. The primary processes we intended to address by treating the wetland as a reservoir was (1) estimating evaporation losses from the wetland, (2) routing water out of the basin if there is a true outlet for overflow, (3) predicting the timing and magnitude of changes in wetland water depth, and (4) quantifying the areal extent of the water surface. The reservoir feature was not included in our functioning APEX model, but it was used in an earlier nonfunctioning version. We believe that inclusion of this feature in our initial model prevented the model from functioning. The guidance received from the CEAP Modeling Team indicated the lack of functionality with this routine was potentially due to using values of zero for several sediment-related parameters of the reservoir feature (that is, reservoir return rate (RSRR), initial sediment concentration in reservoir (RSYS), normal sediment concentration in reservoir(RSYN), reservoir hydraulic conductivity (RSHC), days required to return to normal concentrations (RSDP), and bulk density of sediments in reservoir (RSBD).

\section{Setting Management Variables}

In management data, the study site was represented as a mix of 50 percent little bluestem grass (Schizachyrium scoparium) and 50 percent smooth bromegrass (Bromus inermis). These are considered crops in APEX, so an associated "budget" must be created. In our budget " 1 to 4 Perennial and(or) Annual Crop(s)," with the additional settings of 2 crops (No Till and Dryland) for 50 years was used. After entering the above settings, the option to automatically add operations for the remaining years was chosen. At this point in the setup procedure, hauling operations needed to be specified. WinAPEX forces the user to use a hauling operation, which is clearly not appropriate for areas that are not cut such as the CLSA. To minimize the effect of this, we chose to haul with the smallest vehicle in the list, an All-Terrain vehicle, on June 1 of each year.

\section{Output}

The model output discussed here is subarea-level output. Although APEX ran to completion for the 25-year simulation, considerable refinement is still required to produce representative results. Our collaborative efforts to date have produced encouraging results, and communication with the CEAP Modeling Team has been highly productive. The model is not currently set up to route water from all subareas into the wetland, but inspection of subarea-specific runoff alone indicates 
that two parts of the construct may need improvement: (1) not enough runoff is being produced by any of the subareas to supply enough water to the wetland to maintain the watersurface elevations at the levels that have been observed; and (2) daily runoff values are almost identical across all subareas, which is unexpected due to the marked differences in average slope. The first issue of insufficient runoff recurred throughout the simulation - even in years that had substantial snowpack and are known to have contributed greatly to the seasonal springtime increase in wetland pool volume. Further inspection of other output parameters should show where water is going, and it is likely infiltrating to the subsurface. If water is infiltrating to the subsurface, this could still be representative of the hydrology at the site if the water is moving laterally as return flow to the wetland; however, if the water is infiltrating to recharge deep groundwater, then this model behavior needs to be modified. An interesting feature of the glacial till soil in the PPR that may or may not be captured by APEX is a combination of low vertical conductivity and high lateral conductivity, which tends to allow water to migrate as shallow subsurface flow from the uplands to supply wetlands during spring snowmelt.

The second concern is that daily runoff amounts are the same across subareas despite differences in slope, which was unexpected because the primary reason that subareas are delineated in the present configuration is to honor the differences in average slope across the study site, with the intent of capturing corresponding variation in hydrological processes (particularly runoff in this example). Two possible explanations for the lack of variation across subareas were considered: (1) measured slope differences between subareas are not large enough to create measureable differences in runoff; and (2) runoff differences between subareas actually do exist, but APEX does not consider the subprocesses that cause differences in runoff. Subprocesses that might create such differences include redistribution of snowpack amounts due to wind, or dissimilar snowmelt rates across the site due to slope aspect and solar radiation. For example, more windblown snow is thought to accumulate in uplands where grass is present than where shorter stubble from row crops is the primary groundcover. Investigating such phenomena with this combination of hydrological modeling and the long-term record for the study site may present opportunities for advancement in several areas.

To further explore the source of springtime runoff, the total snowfall for each winter (estimated as the total of daily precipitation amounts from November 1 to April 1) was compared to the modeled daily snow-water equivalent in the snowpack during the same year. In several years of the simulation, modeled snow-water equivalent during the winter reached a maximum less than or equal to 10 percent of the total winter precipitation, whereas in other years the peak modeled snow-water equivalent for the winter was more than 50 percent of total winter precipitation. Some of the deviation of modeled snow-water equivalent from total precipitation is likely due to temperature variations among years that resulted in varying amounts of precipitation contributing to snowpack. Yearly variation in the amount of total precipitation contributing to snow-water equivalent of the snowpack available to influence spring runoff provides an opportunity to improve model estimates of a critical hydrologic input to this system. We suspect the sources of this year-to-year variability in the relation of total winter precipitation to modeled snow-water equivalent are discernible through inspection of the output values for related parameters; therefore, output for each of the 25 years likely has the potential to improve our understanding of prairie hydrology and model behavior. For example, there are S-curve parameters worth considering (that is, SCRP1[16] and SCRP2[16]) as a potential source of the disparity between total precipitation and snow-water equivalent across years. These parameters help define the Snowmelt function in APEX (Steglich and Williams, 2013).

\section{Conclusions from Preliminary APEX Modeling}

The ability to apply APEX to model the hydrology of depressional wetlands using the WinAPEX interface has been demonstrated. The primary challenge is setting up the model in a way that facilitates the basin-scale approach by aggregating the areal extent effectively. GIS tools have been applied to successfully exploit high-resolution elevation data. Specifically, we have developed automated, objective steps that manage the large amount of geospatial information and the requirement to hydrologically condition the DEM in order to take advantage of the valuable detail in these data. Based on our experience with the algorithms used by the GIS extension Arc Hydro, such high-resolution data are extremely desirable input for APEX models of depressional wetlands. We have extended this raster dataset to incorporate another important source of elevation data, bathymetric survey points. The resulting elevation model robustly describes the study site and is a basis for providing detailed input to APEX, as well as allowing comprehensive hydrological and ecological interpretation of APEX output.

Data input and parameter settings for the APEX platform were studied extensively for their application to the current study site, and the potential for more in-depth consideration of these settings now exists in the context of calibrating and validating APEX output. The features of the model that are of particular interest are using the reservoir routine to describe wetland hydroperiod and verifying the appropriate parameter values for stream-related variables. One important process in the natural system where depressional wetlands occur in the PPR is aeolian transport and redeposition of snow, which is not currently addressed in APEX. The role of this process could, however, be investigated through simulations using historical data. 


\section{Other Related Modeling}

Although modeling work under the ILM partnership is currently focused on use of INVEST for regional quantifications and APEX for more detailed process-based modeling, other modeling efforts are relevant to the partnership's overall goals of quantifying ecosystem service effects of conservation programs and practices.

\section{STELLA ${ }^{\text {TM }}$ Dynamic Systems Modeling}

The USGS ILM Team is working to develop a sitespecific model of wetlands at the CLSA. This effort is funded through the USGS Climate and Land-Use Change Mission Area and is generating information and products that directly benefit the overall ILM modeling effort. The CLSA wetlands model is being developed using STELLA ${ }^{\mathrm{TM}}$ dynamic simulation modeling software (Richmond, 2004) and will tie hydrologic and geochemical models to biotic response variables (for example, plants, amphibians, invertebrates, and birds). The base hydrologic model for this effort was completed in 2014. The hydrologic model accurately simulates seasonal water dynamics in closed-basin wetlands. Detailed water-level data from the CLSA was used for model calibration and validation (fig. 11). The goal is to work towards incorporating yearly variation in snowmelt runoff into the model, as spill and fill dynamics connect multiple wetlands into a wetland complex. Additional phases of this modeling effort will focus on integrating geochemical cycling with the hydrologic dynamics and quantification of biotic responses. Information gained from this localized modeling effort will be used to inform the overall ILM modeling efforts using INVEST and APEX.

\section{Development of Predictive Algorithms}

As part of the CEAP-Wetlands effort, algorithms facilitating the prediction of specific variables related to the provisioning of ecosystem services have been developed. To date, algorithm development has been limited primarily to the CEAP-Wetlands High Plains regional assessment team's work for playa wetlands. An example of algorithms developed by the High Plains team is shown in table 7. These algorithms predict amphibian species richness and the probability that a particular species will be present in any given playa wetland. Other algorithms developed by the CEAP-Wetlands High Plains regional assessment team allow for the quantification of floodwater storage, sedimentation, contaminant amelioration, and several plant species richness and vegetation cover

Table 7. Algorithms developed by the CEAP-Wetlands High Plains regional assessment team for predicting amphibian species richness and probability of individual species being present in High Plains playa wetlands.

\begin{tabular}{|c|c|}
\hline Predicted variable & Algorithm (transformed models) \\
\hline Total species richness & $\exp (0.0016115 *$ hydroperiod- $0.0020619 *$ watershed area to playa area ratio +1.0669053$)$ \\
\hline Bufo species richness & $\exp (0.0017388 *$ hydroperiod- 0.2742842$)$ \\
\hline Lithobates species richness & $\exp (0.003747 *$ hydroperiod- $0.039586 *$ watershed area to playa area ratio- 0.651161$)$ \\
\hline Spea presence & $\begin{array}{l}\exp (-0.003407 * \text { Conservation Reserve Program land }+2.661548) /(1+\exp [-0.003407 * \text { Conservation } \\
\quad \text { Reserve Program land }+2.661548])\end{array}$ \\
\hline Anaxyrus cognatus presence & $\exp (0.013830 *$ hydroperiod- 0.010758$) /(1+\exp [0.013830 *$ hydroperiod- 0.010758$])$ \\
\hline Anaxyrus woodhousii presence & $\begin{array}{l}\exp (0.009332 * \text { cropland }-0.009411 * \text { grassland }-3.716480) /(1+\exp [0.009332 * \text { cropland- } \\
0.009411 * \text { grassland }-3.716480])\end{array}$ \\
\hline Anaxyrus debilis presence & $\begin{array}{l}\exp (-0.05487 * \text { Conservation Reserve Program land }+0.02132 * \text { grassland }-3.53401) /(1+\exp [-0.05487 * \\
\text { Conservation Reserve Program land }+0.02132 * \text { grassland-3.53401] })\end{array}$ \\
\hline Acris crepitans presence & $\begin{array}{l}\exp (-0.12349 * \text { watershed area to playa area ratio- }-0.74235) /(1+\exp [-0.12349 * \text { watershed area to playa } \\
\quad \text { area ratio- } 0.74235])\end{array}$ \\
\hline Gastrophryne olivacea presence & $\exp (-0.006338 *$ cropland-1.032310)/(1+exp[-0.006338*cropland-1.032310]) \\
\hline Lithobates blairi presence & $\begin{array}{l}\exp (0.005388 * \text { hydroperiod- } 0.050825 * \text { watershed area to playa area ratio- } 0.185191) / \\
\quad[1+\exp (0.005388 * \text { hydroperiod- } 0.050825 * \text { watershed area to playa area ratio- } 0.185191])\end{array}$ \\
\hline Lithobates catesbeianus presence & $\begin{array}{l}\exp (0.012439 * \text { hydroperiod- } 0.156494 * \text { watershed area to playa area ratio- } 2.719996) / \\
\quad[1+\exp (0.012439 * \text { hydroperiod- } 0.156494 * \text { watershed area to playa area ratio- } 2.719996]))\end{array}$ \\
\hline Ambystoma tigrinum presence & $\exp (0.003649 *$ watershed area-1.325456)/(1+exp[0.003649*watershed area-1.325456] $)$ \\
\hline
\end{tabular}




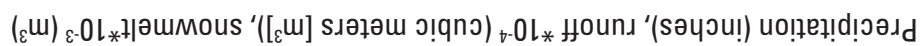

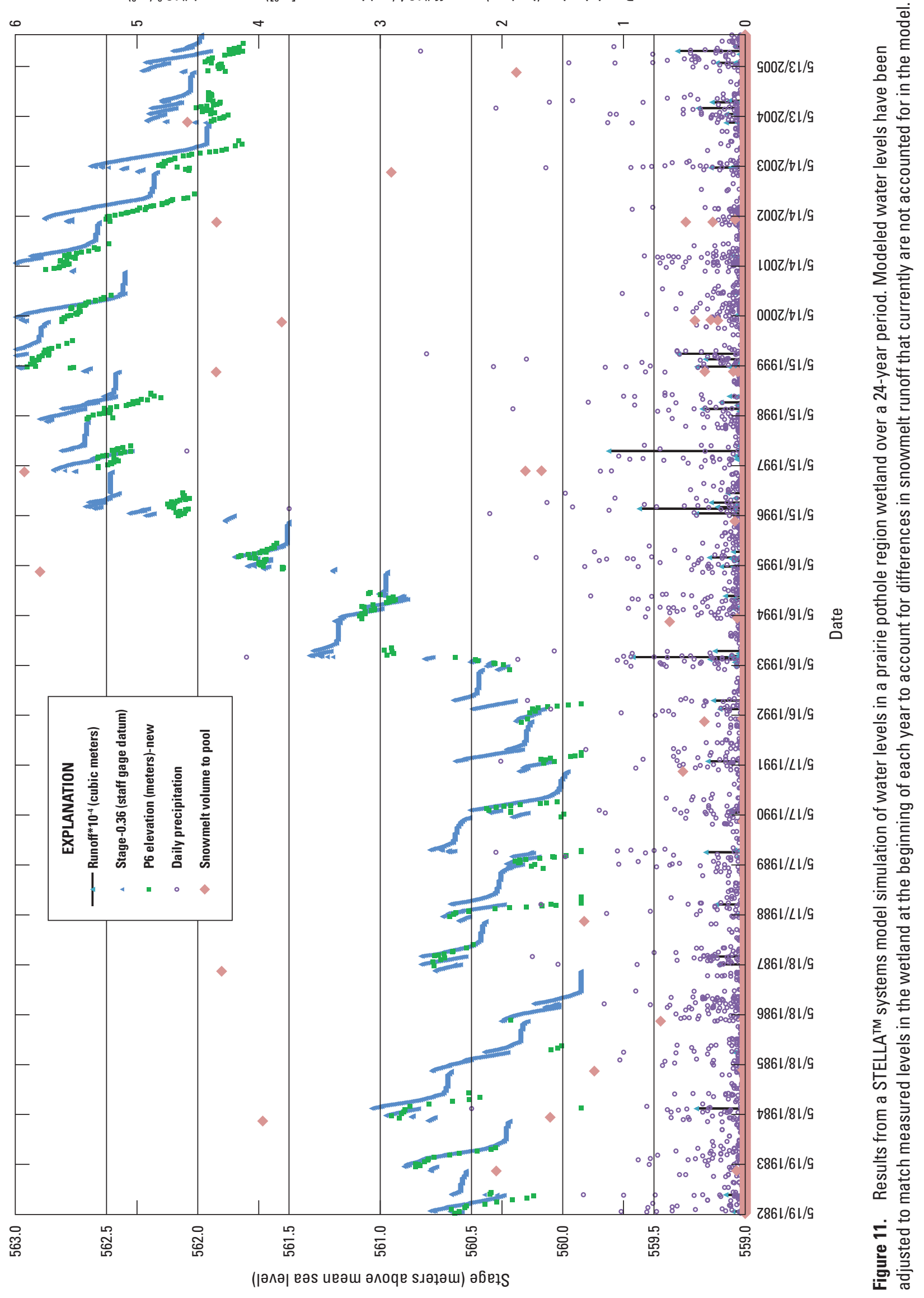


metrics for playa wetlands (Smith and others, 2015). Although the High Plains team has demonstrated success in developing algorithms specific to playa wetlands, development of similar algorithms for other CEAP-Wetlands assessment regions has been hampered, largely due to great year-to-year variability and a lack of data at a temporal resolution sufficient to adequately account for this variability. As an example, in the PPR an attempt was made to develop amphibian occurrence algorithms for prairie pothole wetlands; however, this effort was unsuccessful due to limited sample size and great variability between the 2 years for which wetland data were available (that is, the year was identified as a important variable, effectively requiring that a separate algorithm be developed for each year; Balas and others, 2012). Additionally, PPR regional assessment amphibian data were only available for a single wetland type, seasonal wetlands, out of the multiple wetland types present in the PPR. Although the development of algorithms to predict specific variables of interest is a worthwhile effort, additional data collection efforts will likely be needed to facilitate the development of robust algorithms in regions outside of the High Plains.

\section{Summary}

The Integrated Landscape Modeling (ILM) partnership is an effort by the U.S. Geological Survey (USGS) and U.S. Department of Agriculture (USDA) to identify, evaluate, and develop models to quantify services derived from ecosystems, with a focus on wetland ecosystems and conservation effects. The ILM partnership has matured to the stage where effects of conservation programs and practices on multiple ecosystem services can now be simulated in selected areas. The primary tool being used by the partnership to quantify the ecosystem services provided by wetlands and surrounding upland ecosystem is the INVEST modeling platform. The model testing phase of this effort has focused primarily on the PPR. Services quantified to date include carbon stores, amphibian habitat, plant-community biodiversity and pollination services. Work to include waterfowl and grassland bird habitat quality in INVEST modeling capabilities for the PPR is in progress. The ILM partnership plans to continue to develop and use INVEST's modeling capabilities to provide regional projections of ecosystem services under varying scenarios of interest to USDA (for example, to meet reporting needs of CEAP-Wetlands, Croplands and Grazing Lands; and to facilitate efforts of the FSA Monitoring, Assessment and Evaluation Program). Additionally, work will broaden to develop and test INVEST modeling capabilities beyond the PPR in other regions of the United States.

The ILM partnership is also developing the capability to facilitate process-based modeling of depressional wetland ecosystems using the APEX model. Work to date has focused on developing techniques to use this model in closed-basin depressional wetlands in the PPR in addition to the open systems the model was originally designed to simulate. The CEAP Modeling Team in Temple, Tex., is currently leading APEX modeling work.

Future work for the ILM partnership could also include the exploration of current (for example, National Resources Inventory) and potential future monitoring frameworks to begin including model adaptation capabilities into ILM partnership efforts. The primary goal guiding future work will be to provide improved information on ecosystem services to USDA and DOI in support of reporting needs, to facilitate evaluations of conservation programs and practices, and to facilitate management of the Nation's ecosystems and the services they provide to society.

\section{References Cited}

Ator, S.W., Denver, J.M., LaMotte, A.E., and Sekellick, A.J., 2013, A regional classification of the effectiveness of depressional wetlands at mitigating nitrogen transport to surface waters in the Northern Atlantic Coastal Plain: U.S. Geological Survey Scientific Investigations Report 2012-5266, 23 p.

Balas, C.J., Euliss, N.H., Jr., and Mushet, D.M., 2012, Influence of conservation programs on amphibians in the prairie pothole region: Wetlands, v. 32, p. 333-345.

Beas, B.J., and Smith, L.M., 2015, Amphibian community responses to playa restorations in the Rainwater Basin: Wetlands, v. 34, p. 1247-1253.

Bellrose, F.C., 1980, Ducks, geese and swans of North America, Stackpole Books, Harrisburg, PA, 540 p.

Calderone, N.W., 2012, Insect pollinated crops, insect pollinators and US agriculture - Trend analysis of aggregate data for the period 1992-2009: PLoS One, v. 7, e37235, 27 p., accessed DATE, at http://journals.plos.org/plosone/ article?id=10.1371/journal.pone. 0037235 .

Conservation Effects Assessment Project, Wetlands Plant Working Group, 2015, Assessing the effects of wetland practices in agricultural landscapes-A conceptual model for wetland plant diversity: Washington, D.C., CEAP Science Note, U.S. Department of Agriculture, Natural Resources Conservation Service, Conservation Effects Assessment Project, 5 p., accessed December 28, 2015, at http://www.nrcs.usda.gov/Internet/FSE_DOCUMENTS/ nrcseprd401829.pdf.

Daniel, D.W., Smith, L.M., Belden, J.B., McMurry, S.T., and Swain, S., 2015a, Effects of land-use change and fungicide application on soil respiration in playa wetlands and adjacent uplands of the U.S. High Plains: Science of the Total Environment, v. 514, p. 290-297. 
Daniel, D.W., Smith, L.M., Haukos, D.A., Johnson, L.A., and McMurry, S.T., 2014, Land use and Conservation Reserve Program Effects on the persistence of playa wetlands in the High Plains: Environmental Science \& Technology, v. 48, p. 4282-4288.

Daniel, D.W., Smith, L.M., and McMurry, S.T., 2015b, Land use effects on sedimentation and water storage volumes in playas of the rainwater basin of Nebraska: Land Use Policy, v. 42 , p. $426-431$.

Denver, J., Ator, S., Lang, M., Fisher, T., Gustafson, A., Fox, R., Clune, J., and McCarty, G., 2014, Nitrate fate and transport through current and former depressional wetlands in an agricultural landscape, Choptank Watershed, Maryland, USA: Journal of Soil and Water Conservation, v. 69, p. $1-16$.

Djokic, D., 2008, Comprehensive terrain preprocessing using Arc Hydro tools: Redlands, California, Esri, 61 p.

Duffy, W.G., Kahara, S.N., and Records, R.M., eds., 2011, Conservation effects assessment project-Wetlands assessment in California's Central Valley and Upper Klamath River Basin: U.S. Geological Survey Open-File Report 2011-1290, $128 \mathrm{p}$.

Euliss, N.H., Jr., Brinson, M.M., Mushet, D.M., Smith, L.M., Conner, W.H., Burkett, V.R., Wilcox, D.A., Hester, M.H., and Zheng, H., 2013, Ecosystem services-Developing sustainable management paradigms based on wetland functions and processes, in Anderson, J.T., and Davis, C.A., eds., Wetland techniques, Volume 3-Applications and management: New York, Springer, p. 181-227.

Euliss, N.H., Jr., Smith, L.M., Liu, S., Feng, M., Mushet, D.M., Auch, R.F., and Loveland, T.R., 2010, The need for simultaneous evaluation of ecosystem services and landuse change: Environmental Science and Technology, v. 44, p. 7761-7763.

Faulkner, S., Barrow, W., Jr., Keeland, B., Walls, S., and Telesco, D., 2011, Effects of conservation practices on wetland ecosystem services in the Mississippi Alluvial Valley,: Ecological Applications, v. 21, p. S31-S48.

Feng, M., Liu, S., Euliss, N.H., Jr., Young, C., and Mushet, D.M., 2011, Prototyping an online wetland ecosystem services model using open model sharing standards: Environmental Modeling \& Software, v. 26, p. 458-468.

Fenstermacher, D., Rabenhorst, M., Lang, M., McCarty, G., and Needelman, B., 2014, Distribution, morphometry, and land use of Delmarva bays: Wetlands, v. 34. p. 1219-1228.
Gallant, A.L., Euliss, N.H., Jr., and Browning, Z., 2014, Mapping Large-Area Landscape Suitability for Honey Bees to Assess the Influence of Land-Use Change on Sustainability of National Pollination Services: PLoS ONE v. 9, p. e99268. doi:10.1371/journal.pone.0099268.

Gleason, R.A., Laubhan, M.K., and Euliss, N.H., Jr., eds., 2008, Ecosystem services derived from wetland conservation practices in the United States Prairie Pothole Region with an emphasis on the U.S. Department of Agriculture Conservation and Wetlands Reserve Programs, U.S. Geological Survey Professional Paper 1745, 58 p.

Huang, C., Peng, Y., Lang, M., Yeo, I., and McCarty, G., 2014, Wetland inundation mapping and change monitoring using Landsat and airborne LiDAR data: Remote Sensing of Environment, v.141, p. 231-242.

Hunt, P., Miller, J., Ducey, T., Lang, M., Szogi, A., and McCarty, G., 2014, Denitrification in natural, restored, and converted wetlands of the Delmarva Region of the US: Ecological Engineering, v. 71, p. 438-447.

Interagency Working Group on Social Cost of Carbon, 2013, Technical update of the social cost of carbon regulatory impact analysis: accessed August 5, 2015, at https://www. whitehouse.gov/sites/default/files/omb/inforeg/social_cost_ of_carbon_for_ria_2013_update.pdf.

Kluber, L., Miller, J., Hunt, P., Ducey, T., and Lang, M., 2014, Impact of mid-Atlantic wetland conversion and restoration on greenhouse gas emissions and soil microbial communities: Applied Soil Ecology, v. 76, p. 87-94.

Lang, M., McCarty, G., and Oesterling, R., 2013, Topographic metrics for improved mapping of forested wetlands: Wetlands, v. 33, p. 141-155.

Lonsdorf, E., Ricketts, T., Kremen, C., Winfree, R., Greenleaf, S., and Williams, N., 2011, Crop pollination services, chap. 10 of Kareiva, P., Tallis, H., Ricketts, T.H., Daily, G.C., and Polasky, S., eds., Natural capital-Theory and practice of mapping ecosystem services: Oxford, New York, Oxford University Press, p. 168-187.

Maxwell, E.L., 1998, METSTAT-The solar radiation model used in the production of the National Solar Radiation Database (NSRDB): Solar Energy, v. 62, p. 263-279.

McDonough, O., Lang, M., Hosen, J., and Palmer, M., 2014, Surface hydrologic connectivity between Delmarva Bay wetlands and nearby streams along a gradient of agricultural alteration: Wetlands, v.35, p. 41-53. 
McFarland, E., LaForgia, M., Yepsen, M., Whigham, D., Baldwin, A., and Lang, M., in press, Plant biomass and nutrients $(\mathrm{C}, \mathrm{N}$, and $\mathrm{P})$ in natural, restored, and prior converted depressional wetlands in the mid-Atlantic Coastal Plain: U.S. Folia Geobotantica.

Millennium Ecosystem Assessment, 2005, Ecosystems and human well-being - Wetlands and water synthesis: Washington, D.C., World Resources Institute, 80 p.

Mitchell, J., in press, Amphibian use of restored wetlands in agricultural landscapes in the mid-Atlantic Region, USA: Journal of Fish and Wildlife Management.

Mushet, D.M., Neau, J.L., and Euliss, N.H., Jr., 2014, Modeling effects of conservation grassland losses on amphibian habitat: Biological Conservation, v. 174, p. 93-100.

National Oceanic and Atmospheric Administration, 2013, National Climatic Data Center: accessed August 10, 2013, at http://www.ncdc.noaa.gov/.

National Solar Radiation Data Base, 2013, Data sets: accessed December 10, 2013, at http://rredc.nrel.gov/solar/old_data/ $\mathrm{nsrdb} /$.

Natural Capital Project, 2013, INVEST Version 2.4.5.: accessed December 18, 2015, at http:/www.naturalcapitalproject.org/invest.

Natural Capital Project, 2015, Carbon storage and sequestration: climate regulation: accessed December 18, 2015, at http://data.naturalcapitalproject.org/nightly-build/investusers-guide/html/carbonstorage.html\#summary.

North Dakota Agricultural Weather Network, 2013, NDAWN Center: accessed December 5, 2013, at http://ndawn.ndsu. nodak.edu/.

O’Connell, J.L., Johnson, L.A., Smith, L.M., McMurry, S.T., and Haukos, D.A., 2012, Influence of land-use and conservation programs on wetland plant communities of the semiarid United States Great Plains: Biological Conservation, v. 146 , p. 108-115.

Omernik, J.M., 1987, Ecoregions of the conterminous United States: Annals of the Association of American Geographers, v. 77, p. 118-125, 1 map sheet, scale 1:7,500,000.

Perez, R., Ineichen, P., Moore, K., Kmiecik, M., Chain, C., George, R., and Vignola, F., 2002, A new operational model for satellite-derived irradiances-Description and validation: Solar Energy, v. 73, p. 307-317.

QCoherent Software, 2013, Getting started with LP360: Colorado Springs, Colorado, QCoherent Software, 13 p., accessed December 10, 2013, at www.qcoherent.com/products/docs/lp360_gettingstarted.pdf.
Richmond, B., 2004, An introduction to systems thinking-A STELLA software guide book: Lebanon, New Hampshire, Isee Systems, Inc., 165 p.

Sauer, J.R., Hines, J.E., Fallon, J.E., Pardieck, K.L., Ziolkowski, D.J., Jr., and Link, W.W., 2014, The North American breeding bird survey-Results and analysis 1966-2013, Version 01.30.2015: Laurel, Maryland, U.S. Geological Survey, Patuxent Wildlife Research Center, accessed December 28, 2015, at http:/www.mbr-pwrc.usgs. gov/bbs/bbs.html.

Smith, L.M., Effland, W.R., Behrman, K.D., and Johnson, M.V., 2015, Assessing the effects of USDA conservation programs in ecosystem services provided by wetlands. National Wetlands Newsletter, v. 37, p. 10-14.

Soil Survey Staff, 2013, Soil Survey Geographic (SSURGO) Database for Stutsman County, North Dakota: Natural Resources Conservation Service, United States Department of Agriculture, accessed December 18, 2015, at http://www. nrcs.usda.gov/wps/portal/nrcs/main/soils/survey/geo/.

Steglich, E.M., and Francis, L., 2008, Creating a WinEPIC/ CroPMan/WinAPEX database and related files for your area using the Texas central database: Temple, Texas, Blackland Research and Extension Center, BREC Report 2008-15, $22 \mathrm{p}$.

Steglich, E.M., and Williams, J.R., 2013, Agricultural Policy/ Environmental eXtender Model user's manual version 0806: Temple, Texas, Blackland Research and Extension Center, $228 \mathrm{p}$.

Swink, F., and Wilhelm, G., 1994, Floristic quality assessment, in Swink, F., and Wilhelm, G., eds., Plants of the Chicago region: Indianapolis, Indiana, Indiana Academy of Science, p. $14-18$.

U.S. Fish and Wildlife Service, 2015, National Wetlands Inventory, accessed July 12, 2015, at http://www.fws.gov/ wetlands/index.html.

Venne, L.S., Tsai, J.S., Cox, S.B., Smith, L.M., and McMurry, S.T., 2012, Amphibian community richness in cropland and grassland playas in the Southern High Plains, USA: Wetlands, v. 32, p. 619-629.

Vigerstol, K.L., and Aukema, J.E., 2011, A comparison of tools for modeling freshwater ecosystem services: Journal of Environmental Management, v. 92, p. 2403-2409.

Villa, F., Bagstad, K.J., Voigt, B., Johnson, G.W., Portela, R., Horzak, M., and Batker, D., 2014, A methodology for adaptable and robust ecosystem services assessments: PLoS One, v. 9, e91001, 18 p. 
Wechsler, S.P., 2007, Uncertainties associated with digital elevation models for hydrologic applications-A review: Hydrology and Earth System Sciences, v. 11, p.14811500 .

Wilcox, S., 2007, National Solar Radiation Database 19912005 update-User's manual: Golden, Colorado, National Renewal Energy Laboratory, 462 p.

Williams, J.R., and Berndt, H.D., 1977, Sediment yield predictions based on watershed hydrology: Transactions of the American Society of Agricultural Engineers, v. 20, p. 1100-1104.

Winter, T.C., 2003, Hydrological, chemical, and biological characteristics of a prairie pothole wetland complex under highly variable climate conditions - The Cottonwood Lake area, east-central North Dakota: U.S. Geological Survey Professional Paper 1675, 109 p.
Yepsen, M., Baldwin, A., Whigham, D., McFarland, E., LaForgia, M., and Lang, M., 2014, Agricultural wetland restorations achieve diverse native wetland plant communities but differ from undisturbed wetlands: Agriculture, Ecosystems, and Environment, v. 197, p. 11-20.

Zimpfer, N.L., Rhodes, W.E., Silverman, E.D., Zimmerman, G.S., and Richkus, K.D., Trends in duck breeding populations, 1955-2014: Laurel, Maryland, U.S. Fish and Wildlife Services, Division of Migratory Birds, $23 \mathrm{p}$.

Zhang, W., and Montgomery, D., 1994, Digital elevation model grid size, landscape representation, and hydrologic simulations: Water Resources Research, v. 30, p. 1019-1028.

Zhang, X., Drake, N.A., Wainwright, J., and Mulligan, M., 1999, Comparison of slope estimates from low resolution DEMsScaling issues and a fractal method for their solution: Earth Surface Processes and Landforms, v. 24, p. 763-779. 
Appendixes 1-8 


\title{
Appendix 1. Memorandum of Understanding
}

NRCS 68-3A75-7-8

\author{
MEMORANDUM OF UNDERSTANDING \\ AMONG THE \\ UNITED STATES GEOLOGICAL SURVEY, \\ UNITED STATES FISH AND WILDLIFE SERVICE, \\ NATURAL RESOURCES CONSERVATION SERVICE, \\ COMMODITY CREDIT CORPORATION, \\ AND \\ FARM SERVICE AGENCY
}

\begin{abstract}
A PARTNERSHIP TO SUPPORT RESEARCH, DEVELOPMENT, AND INFORMATION
TRANSFER TO QUANTIFY THE CONSERVATION BENEFITS OF LAND

MANAGEMENT PRACTICES AND PROGRAMS ADMINISTERED BY THE U.S. DEPARTMENT OF THE INTERIOR (DOI) AND THE U.S. DEPARTMENT OF AGRICULTURE (USDA)
\end{abstract}

\section{AUTHORITY AND MECHANISMS FOR COOPERATION}

The authority of the Agencies to enter into this Memorandum of Understanding (MOU) are the Soil Conservation and Domestic Allotment Act (16 U.S.C. 590 a-590f), Public Law 74-46; Fish and Wildlife Coordination Act (16 U.S.C. 661-667e); Fish and Wildlife Act of 1956 (16 U.S.C. 742(a)-754); the U.S. Geological Survey (USGS) Organic Act (43 U.S.C. 36c); and the Commodity Credit Corporation (CCC) Charter Act (15 U.S.C. 714). To the extent future grants and/or cooperative agreements are issued by the Agencies to any vendor or university, they will be issued in adherence to all applicable Federal laws and regulations.

\section{PURPOSE}

This MOU is made and entered into among the U.S. Department of Agriculture, Natural Resources Conservation Service (NRCS), CCC, Farm Service Agency (FSA) and the U.S. Department of the Interior, Fish and Wildlife Service (FWS) and USGS, hereinafter referred to as the Agencies. The purpose of this MOU is to establish and define areas of cooperation between the Agencies to conduct research and to develop information and technology to increase the effectiveness of land management practices on the conservation of physical and biological components of ecological systems in the United States. The Agencies administer and research various programs (e.g., Partners for Fish and Wildlife Program, Conservation Reserve Program (CRP), Wetlands Reserve Program (WRP), Environmental Quality Incentives Program (EQIP)) having similar goals and objectives such that a collaborative venture involving each Agency would be beneficial for addressing multiple needs of mutual interest to all Agencies. 


\section{BACKGROUND AND MUTUAL BENEFITS AND INTERESTS}

Cooperation through this MOU will provide the Agencies with a methodology to quantify the benefits of conservation and land management practices and programs and provide information essential to their improvement. More specifically, this MOU will facilitate development and evaluation of methods to assist the Agencies in efforts to determine the effectiveness of conservation practices and programs targeting both uplands and wetlands at multiple scales. Accomplishing this goal will require development of methodologies to document improvements in a wide array of conservation benefits, including but not limited to, floodwater storage, sediment dynamics, water quality, carbon sequestration, and various measures of biological response. It will build on existing data and the collective capabilities of the Agencies in monitoring, research, technology development, and information transfer. Additional benefits include (1) increased scientific knowledge of system processes leading to enhanced conservation and land management programs and practices, (2) development of a common set of conservation measures across agencies using standard terms, (3) improved communication and more comprehensive reporting of program accomplishments, and (4) development of a network for sharing data among Agencies to the maximum extent possible within the regulatory constraints of each individual Agency.

This MOU establishes a structure and mechanism for cooperation between Agencies but does not preclude the independent execution of contracts or other agreements by individual Agencies.

Representatives of the Agencies have previously identified specific areas of mutual interest and opportunities for collaboration. Establishment of a formal interagency partnership through this MOU represents a continuation and broadening of that collaboration to enhance the conservation of natural resources. This collaboration among Agencies will attract academic and other scientists from multiple disciplines and will lead to development of a broader network of partnering scientists to assist in identifying, developing, and implementing this and other projects of mutual benefit.

\section{SCOPE}

The Agencies will cooperate on mutually agreed upon projects to evaluate methodologies to quantify the benefits of conservation practices implemented by the Agencies in the United States. Participation in each project by an agency is voluntary. Expansion to a national evaluation is the long-term goal of the Agencies but initial pilot work will be conducted at a regional scale, such as in the Prairie Pothole and the Lower Mississippi Valley Regions, to explore procedures and test approaches. This will minimize costs associated with the exploratory analysis and make expansion to other regions more efficient. Development of compatible methodologies in other regions or ecological systems will be initiated to refine the approach and data collection used in the regional pilots. Ultimately, work may be on-going in multiple regions simultaneously.

At a national scale, initial activities under this MOU will focus in the following areas:

1) Development of a national concept document for evaluation of conservation benefits of covered USDA and DOI programs

2) Development of an effective communication network within and among Agencies at different levels within each organization 
3) Selection of project areas

4) Project specific identification of conservation benefits to be quantified, including the precision required and the temporal periodicity of reporting results.

\section{IMPLEMENTATION AND RESPONSIBILITIES}

The Agencies agree to establish a Technical Steering Committee for each regional project that will consist of at least two members from each participating Agency. Each Technical Steering Committee will collaboratively establish project goals; plan monitoring, research, and development activities; keep members of the Executive Committee informed about progress and problems; and report annually on accomplishments related to the project. The Agencies will share resources as appropriate and will work together to ensure the integrity and quality of project goals. An Executive Steering Committee composed of at least one member (and, optionally, one alternate) from each Agency will be established to provide national oversight and long-term direction; secure supporting resources and support the Technical Steering Committees; consider priorities and conflicts; and champion the cooperative effort from a national perspective.

\section{FINANCIAL ARRANGEMENTS}

A. This MOU defines in general terms the basis on which signatory Agencies will cooperate, and as such, does not obligate the expenditure of any funds. Expenditures of funds, human resources, equipment, supplies, facilities, training, public information, and expertise will be provided by each signatory Agency to the extent that their participation is required and resources are available to achieve the products identified by the signatory Agency.

B. This MOU is neither a fiscal nor funds obligation document. Any endeavor involving reimbursement or contribution of funds between parties of this MOU will be handled in accordance with applicable laws, regulations, and procedures. Such endeavors will be documented in separate agreements, with specific projects between parties articulated; separate agreements will reference this MOU.

C. This MOU in no way restricts the Agencies from participating in similar activities or arrangements with other public or private agencies, organizations, or individuals.

D. Nothing in this MOU will obligate the Agencies to expend appropriations or to enter into any contracts or other obligations.

\section{DATA DISTRIBUTION ARRANGEMENTS}

\section{USDA}

The exchange of data by the NRCS and the FSA, and the use of such data by the Agencies, will be carried out in compliance with section 1244(b) of the Food Security Act of 1985, 16 U.S.C. 3844(b), and applicable implementing regulations. Data will be shared on a project-by-project basis and will be used only for that project. Where the same data is needed by more than one project facilitated by this MOU, this need will be identified in the specific project funding agreement between the MOU signatories involved to expedite data distribution. 


\section{PERIOD OF AGREEMENT}

This MOU will become effective as of the date of approval of the last signature and will continue in effect for a period of 5 years, which is currently the amount of time permitted under the statutory limitations. No extension of time will be permitted. This MOU may be cancelled, renegotiated, amended, or modified by a written amendment through an exchange of correspondence between authorized officials of the signatory parties.

Any Agency may terminate or withdraw from this MOU at any time before the expiration date by providing 30-day written notice to all other signatory Agencies.

\section{PROVISIONS}

As a condition of this MOU, all signatory parties assure and certify that this MOU, and any agreements written pursuant to this MOU, will comply with the nondiscrimination provisions contained in Title VI and VII of the Civil Rights Act of 1964, as amended; the Civil Rights Restoration Act of 1987 (Public Law 100-259); and other nondiscriminatory statutes. They also will be in accordance with regulations of the Secretary of Agriculture (7 CFR 15, Subpart A.B.), which provides that no person in the United States shall, on the grounds of race, national origin, age, sex, religion, marital status, or disability be excluded from participating in, be denied the benefits of, or be otherwise subjected to discrimination under any program or activity receiving Federal financial assistance from the U.S. Department of Agriculture, or any agency thereof. Regulation of the Secretary of the Interior (43 CFR 17) provides that no person in the United States shall, on the grounds of race, color, national origin, age, or disability be excluded from participating in, be denied the benefits of, or be otherwise subjected to discrimination under any program or activity receiving Federal financial assistance from the U.S. Department of the Interior, or any agency thereof. This MOU and any agreements will be in accordance with such regulations.

Annual progress reports and the final technical report are to be submitted to the Agencies administrative and technical contacts listed below.

\section{TECHNICAL AND ADMINISTRATIVE CONTACTS}

NRCS Administrative Contact:

Karen Minor

Grants and Agreements Specialist

Management Services Division

Natural Resources Conservation Service

P. O. Box 2890, Room 5224-S

Washington, DC 20013-2890

Telephone: (202) 720-2929

Facsimile: (202) 720-7149

Email: karen.minor@wdc.usda.gov

NRCS Technical Contact:

Diane Eckles 
Biologist

Natural Resource Conservation Service

5601 Sunnyside Avenue, 1-1278B

Beltsville, MD 20705

Telephone: (301) 504-2312

Facsimile: (301) 504-3788

Email: diane.eckles@wdc.usda.gov

USGS Administrative Contact:

Valerie Leonard

Program Specialist

Office of the Director

U.S. Geological Survey

12201 Sunrise Valley Drive, MS 114

Reston, VA 20192

Telephone: (703) 648-4406

Facsimile: (703) 648-7031

Email: vleonard@usgs.gov

USGS Technical Contact:

Richard Kearney

Wildlife Program Coordinator

U.S. Geological Survey

12201 Sunrise Valley Drive, MS 301

Reston, VA 20192

Telephone: (703) 648-4019

Facsimile: (703) 648-4238

Email: rkearney@usgs.gov

FWS Administrative Contact:

Dr. Mamie Parker

Assistant Director, Fisheries and Habitat Conservation

U.S. Fish and Wildlife Service

1849 C Street NW (Room 3245)

Washington, DC 20240

Telephone: (202) 208-6394

Facsimile: (202) 208-4674

Email: mamie_parker@fws.gov

FWS Technical Contact:

David Walker

Farm Conservation Programs Coordinator

U.S. Fish and Wildlife Service

4401 North Fairfax Drive, Room 412a

Arlington, VA 22203

Telephone: (703) 358-2310

Facsimile: (703) 358-2232

Email: dave_walker@fws.gov 
FSA Administrative Contact:

John Johnson

Deputy Administrator for Farm Programs

Farm Service Agency

South Agricultural Building

Stop 0510

Washington, DC 20250

Telephone: (202) 720-3175

Facsimile: (202) 720-4726

Email: john.johnson@wdc.usda.gov

FSA Technical Contact:

Skip Hyberg

Economic Policy Analysis Staff

Farm Service Agency

South Agricultural Building

Stop 0519

Washington, DC 20250

Telephone: (202) 720-9222

Facsimile: (202) 720-9617

Email: skip.hyberg@wdc.usda.gov 
X. APPROVALS

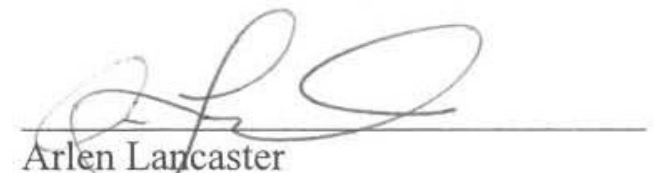

Arlen Lancaster

$\frac{\text { MA2 22, } 2007}{\text { Date }}$

Chief, Natural Resources Conservation Service

U.S. Department of Agriculture

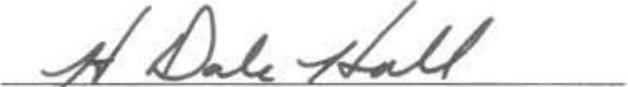

H.Dale Hall

Director, U.S. Fish and Wildlife Service

U.S. Department of the Interior

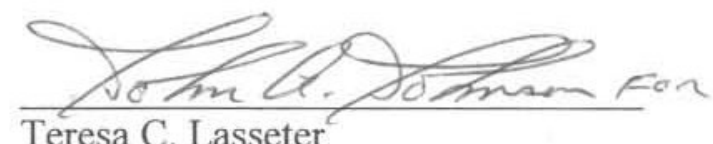

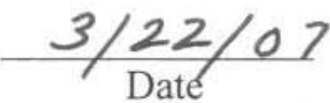

Administrator, Farm Service Agency and Executive Vice President, CCC U.S. Department of Agriculture
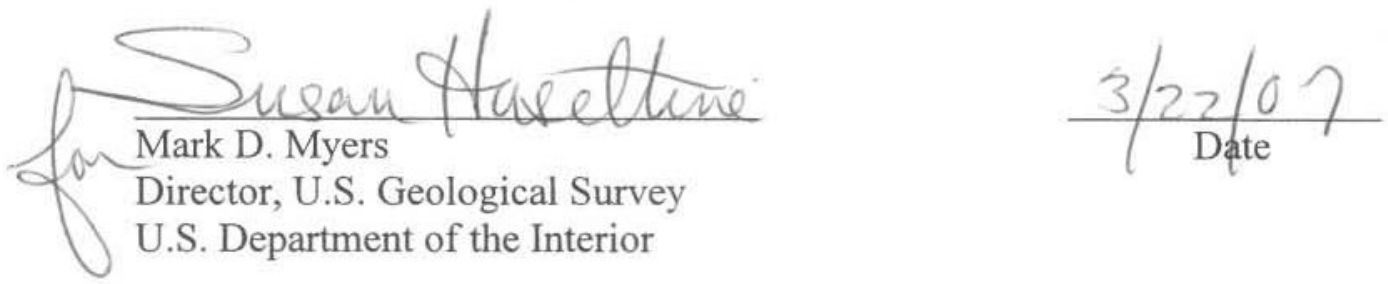


\section{Appendix 2. Completed Integrated Valuation of Ecosystem Services and Tradeoffs (INVEST) Threat and Susceptibility Tables used in Evaluations of Amphibian Habitat in the Prairie Pothole Region of the United States (reproduced from Mushet and others, 2014)}

Table 2-1. Integrated Valuation of Ecosystem Service and Tradeoffs (INVEST) threat table for amphibian habitat model.

[From Mushet and others, 2014]

\begin{tabular}{cccl}
\hline MAX_DIST & WEIGHT & DECAY & \multicolumn{1}{c}{ Threat } \\
\hline 1.0 & 0.6 & 1 & Croplands \\
0.5 & 0.2 & 1 & Permanent hydroperiod \\
0.1 & 0.1 & 1 & Temporary hydroperiod \\
0.1 & 0.1 & 1 & Isolation \\
\hline
\end{tabular}

Table 2-2. Integrated Valuation of Ecosystem Service and Tradeoffs (INVEST) susceptibility table for amphibian habitat model.

[From Mushet and others, 2014. CRP, Conservation Reserve Program; NLCD, National Land Cover Data]

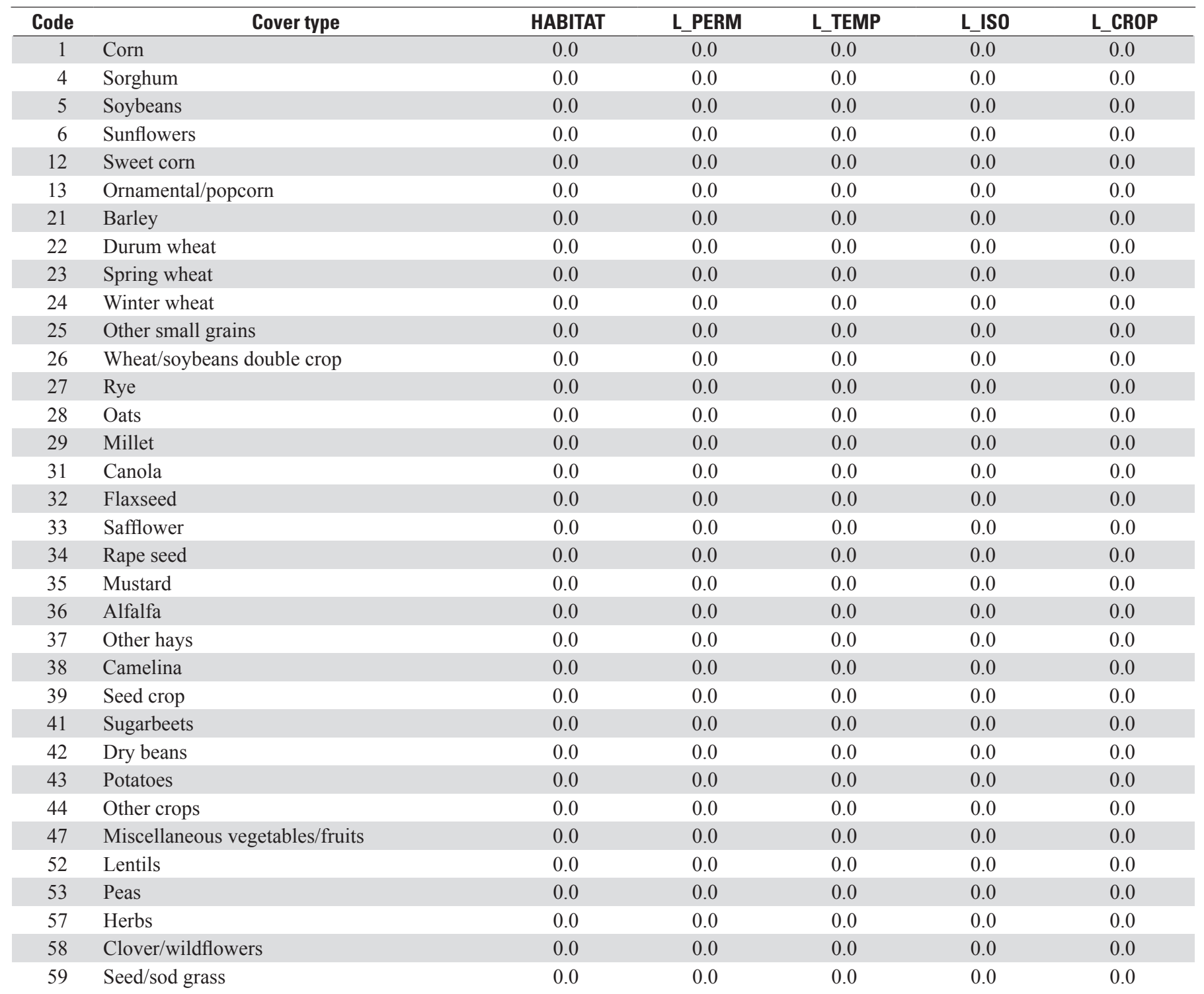


Table 2-2. Integrated Valuation of Ecosystem Service and Tradeoffs (INVEST) susceptibility table for amphibian habitat model.Continued

[From Mushet and others, 2014. CRP, Conservation Reserve Program; NLCD, National Land Cover Data]

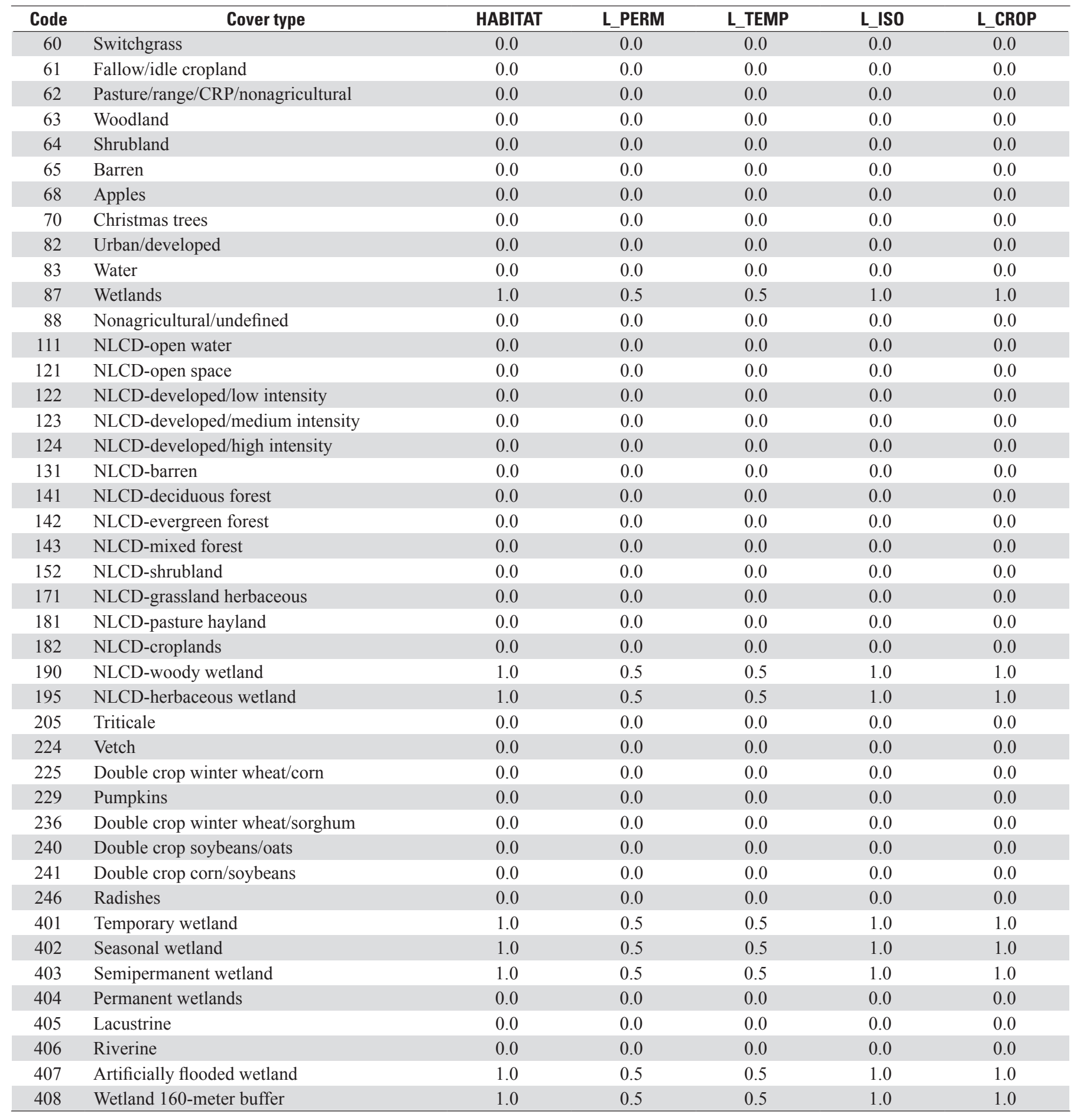




\section{Appendix 3. Vegetation (Living and Dead) and Soil (Organic and Inorganic) Carbon Pool Estimates in Megagrams per Hectare for the Northern and Northwestern Glaciated Plains Ecoregions}

Table 3-1. Vegetation (living and dead) and soil (organic and inorganic) carbon pool estimates in megagrams per hectare for the Northwestern and Northern Glaciated Plains ecoregions.

[CRP, Conservation Reserve Program; NLCD, National Land Cover Data]

\begin{tabular}{|c|c|c|c|c|c|}
\hline \multirow{2}{*}{ Code } & \multirow{2}{*}{ Cover type } & \multicolumn{2}{|c|}{ Northwestern Glaciated Plains } & \multicolumn{2}{|c|}{ Northern Glaciated Plains } \\
\hline & & Vegetation & Soil & Vegetation & Soil \\
\hline 1 & Corn & 0.00 & 48.05 & 0.00 & 46.19 \\
\hline 4 & Sorghum & 0.00 & 48.05 & 0.00 & 46.19 \\
\hline 5 & Soybeans & 0.00 & 48.05 & 0.00 & 46.19 \\
\hline 6 & Sunflowers & 0.00 & 48.05 & 0.00 & 46.19 \\
\hline 12 & Sweet corn & 0.00 & 48.05 & 0.00 & 46.19 \\
\hline 13 & Ornamental/pop corn & 0.00 & 48.05 & 0.00 & 46.19 \\
\hline 21 & Barley & 0.00 & 48.05 & 0.00 & 46.19 \\
\hline 22 & Durum wheat & 0.00 & 48.05 & 0.00 & 46.19 \\
\hline 23 & Spring wheat & 0.00 & 48.05 & 0.00 & 46.19 \\
\hline 24 & Winter wheat & 0.00 & 48.05 & 0.00 & 46.19 \\
\hline 25 & Other small grains & 0.00 & 48.05 & 0.00 & 46.19 \\
\hline 26 & Wheat/soybeans double crop & 0.00 & 48.05 & 0.00 & 46.19 \\
\hline 27 & Rye & 0.00 & 48.05 & 0.00 & 46.19 \\
\hline 28 & Oats & 0.00 & 48.05 & 0.00 & 46.19 \\
\hline 29 & Millet & 0.00 & 48.05 & 0.00 & 46.19 \\
\hline 31 & Canola & 0.00 & 48.05 & 0.00 & 46.19 \\
\hline 32 & Flaxseed & 0.00 & 48.05 & 0.00 & 46.19 \\
\hline 33 & Safflower & 0.00 & 48.05 & 0.00 & 46.19 \\
\hline 34 & Rape seed & 0.00 & 48.05 & 0.00 & 46.19 \\
\hline 35 & Mustard & 0.00 & 48.05 & 0.00 & 46.19 \\
\hline 36 & Alfalfa & 1.54 & 53.05 & 1.88 & 51.19 \\
\hline 37 & Other hays & 1.54 & 53.05 & 1.88 & 51.19 \\
\hline 38 & Camelina & 0.00 & 48.05 & 0.00 & 46.19 \\
\hline 39 & Seed crop & 0.00 & 48.05 & 0.00 & 46.19 \\
\hline 41 & Sugarbeets & 0.00 & 48.05 & 0.00 & 46.19 \\
\hline 42 & Dry beans & 0.00 & 48.05 & 0.00 & 46.19 \\
\hline 43 & Potatoes & 0.00 & 48.05 & 0.00 & 46.19 \\
\hline 44 & Other crops & 0.00 & 48.05 & 0.00 & 46.19 \\
\hline 47 & Miscellaneous vegetables/fruits & 0.00 & 48.05 & 0.00 & 46.19 \\
\hline 52 & Lentils & 0.00 & 48.05 & 0.00 & 46.19 \\
\hline 53 & Peas & 0.00 & 48.05 & 0.00 & 46.19 \\
\hline 57 & Herbs & 0.00 & 48.05 & 0.00 & 46.19 \\
\hline 58 & Clover/wildflowers & 0.00 & 48.05 & 0.00 & 46.19 \\
\hline 59 & Seed/sod grass & 0.00 & 48.05 & 0.00 & 46.19 \\
\hline
\end{tabular}


Table 3-1. Vegetation (living and dead) and soil (organic and inorganic) carbon pool estimates in megagrams per hectare for the Northwestern and Northern Glaciated Plains ecoregions.-Continued

[CRP, Conservation Reserve Program; NLCD, National Land Cover Data]

\begin{tabular}{|c|c|c|c|c|c|}
\hline \multirow{2}{*}{ Code } & \multirow{2}{*}{ Cover type } & \multicolumn{2}{|c|}{ Northwestern Glaciated Plains } & \multicolumn{2}{|c|}{ Northern Glaciated Plains } \\
\hline & & Vegetation & Soil & Vegetation & Soil \\
\hline 60 & Switchgrass & 1.54 & 53.05 & 1.88 & 51.19 \\
\hline 61 & Fallow/idle cropland & 0.00 & 48.05 & 0.00 & 46.19 \\
\hline 62 & Pasture/range/CRP/nonagricultural & 1.54 & 53.05 & 1.88 & 51.19 \\
\hline 64 & Shrubland & 0.00 & 0.00 & 0.00 & 0.00 \\
\hline 87 & Wetlands & 0.68 & 53.13 & 1.71 & 53.56 \\
\hline 171 & NLCD-grassland herbaceous & 1.54 & 53.05 & 1.88 & 51.19 \\
\hline 181 & NLCD-pasture hayland & 1.54 & 53.05 & 1.88 & 51.19 \\
\hline 182 & NLCD-croplands & 0.00 & 48.05 & 0.00 & 46.19 \\
\hline 190 & NLCD-woody wetland & 0.68 & 53.13 & 1.71 & 53.56 \\
\hline 195 & NLCD-herbaceous wetland & 0.68 & 53.13 & 1.71 & 53.56 \\
\hline 205 & Triticale & 0.00 & 48.05 & 0.00 & 46.19 \\
\hline 224 & Vetch & 0.00 & 48.05 & 0.00 & 46.19 \\
\hline 225 & Double crop winter wheat/corn & 0.00 & 48.05 & 0.00 & 46.19 \\
\hline 229 & Pumpkins & 0.00 & 48.05 & 0.00 & 46.19 \\
\hline 236 & Double crop winter wheat/sorghum & 0.00 & 48.05 & 0.00 & 46.19 \\
\hline 240 & Double crop soybeans/oats & 0.00 & 48.05 & 0.00 & 46.19 \\
\hline 241 & Double crop corn/soybeans & 0.00 & 48.05 & 0.00 & 46.19 \\
\hline 246 & Radishes & 0.00 & 48.05 & 0.00 & 46.19 \\
\hline 401 & Temporary wetland & 0.68 & 53.13 & 1.71 & 53.56 \\
\hline 402 & Seasonal wetland & 0.68 & 53.13 & 1.71 & 53.56 \\
\hline 403 & Semipermanent wetland & 0.68 & 53.13 & 1.71 & 53.56 \\
\hline 407 & Artificially flooded wetland & 0.68 & 53.13 & 1.71 & 53.56 \\
\hline 408 & Wetland 150-meter buffer & 1.54 & 53.05 & 1.88 & 51.19 \\
\hline 600 & Wetland within grassland & 1.81 & 58.13 & 2.21 & 58.56 \\
\hline
\end{tabular}




\section{Appendix 4. Completed Integrated Valuation of Ecosystem Services and Tradeoffs (INVEST) Threat and Susceptibility Tables used in Evaluations of Native Plant Communities in the Prairie Pothole Region of the United States}

Table 4-1. Integrated Valuation of Ecosystem Services and Tradeoffs (INVEST) threat table for plant community model.

[CRP, Conservation Reserve Program]

\begin{tabular}{cccl}
\hline MAX_DIST & WEIGHT & DECAY & \multicolumn{1}{c}{ Threat } \\
\hline 0.5 & 0.5 & 1 & CRP Grasslands \\
0.5 & 1.0 & 1 & Croplands \\
0.5 & 0.5 & 1 & Isolation \\
\hline
\end{tabular}

Table 4-2. Integrated Valuation of Ecosystem Services and Tradeoffs (INVEST) susceptibility table for plant community model. [CRP, Conservation Reserve Program; NLCD, National Land Cover Data]

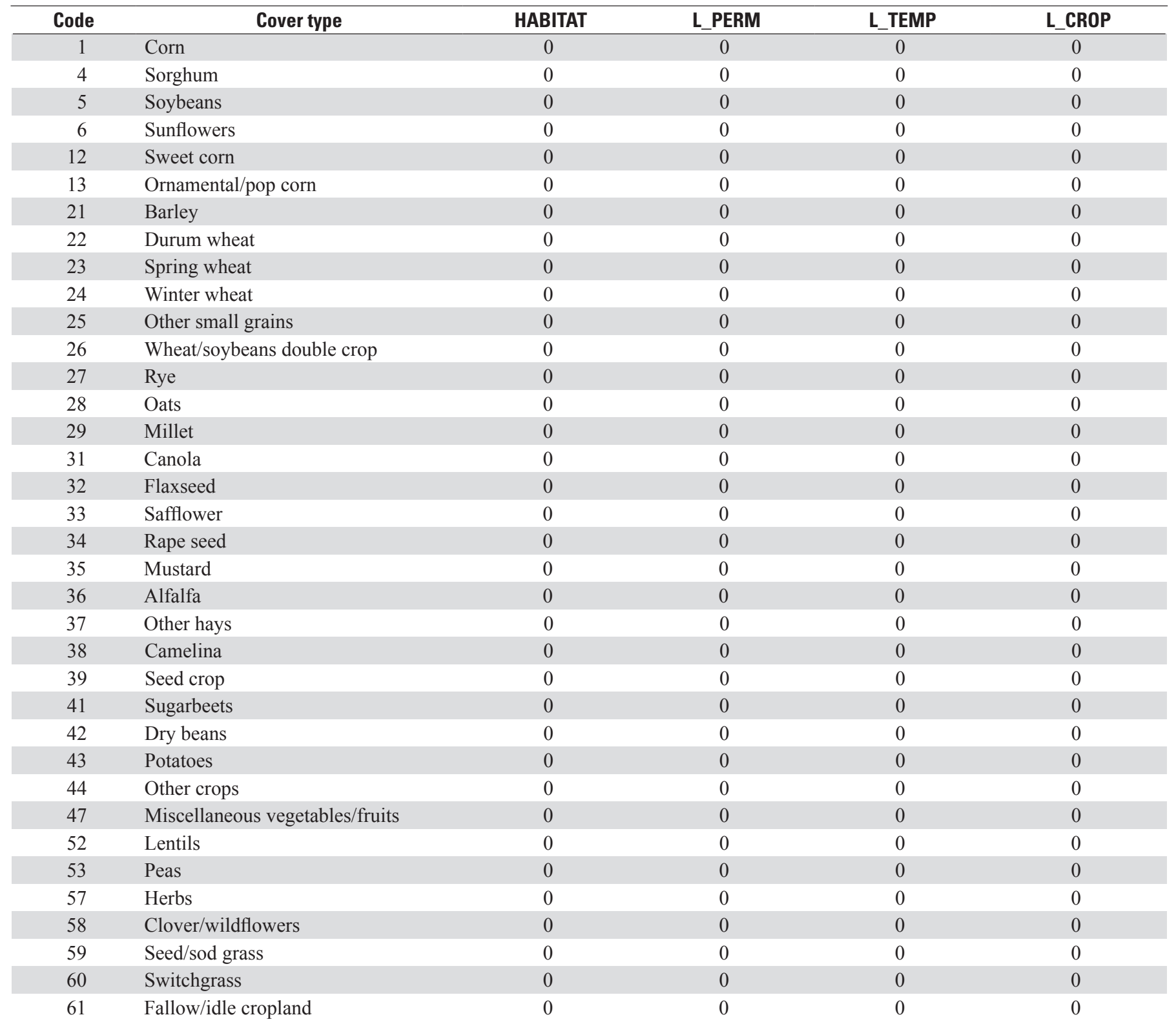


Table 4-2. Integrated Valuation of Ecosystem Services and Tradeoffs (INVEST) susceptibility table for plant community model.— Continued

[CRP, Conservation Reserve Program; NLCD, National Land Cover Data]

\begin{tabular}{|c|c|c|c|c|c|}
\hline Code & Cover type & HABITAT & L_PERM & L_TEMP & L_CROP \\
\hline 62 & Pasture/range/CRP/nonagricultural & 0 & 0 & 0 & 0 \\
\hline 63 & Woodland & 0 & 0 & 0 & 0 \\
\hline 64 & Shrubland & 0 & 0 & 0 & 0 \\
\hline 65 & Barren & 0 & 0 & 0 & 0 \\
\hline 68 & Apples & 0 & 0 & 0 & 0 \\
\hline 69 & Grapes & 0 & 0 & 0 & 0 \\
\hline 70 & Christmas trees & 0 & 0 & 0 & 0 \\
\hline 82 & Urban/developed & 0 & 0 & 0 & 0 \\
\hline 83 & Water & 0 & 0 & 0 & 0 \\
\hline 87 & Wetlands & 0 & 0 & 0 & 0 \\
\hline 88 & Nonagricultural/undefined & 0 & 0 & 0 & 0 \\
\hline 111 & NLCD-open water & 0 & 0 & 0 & 0 \\
\hline 121 & NLCD-open space & 0 & 0 & 0 & 0 \\
\hline 122 & NLCD-developed/low intensity & 0 & 0 & 0 & 0 \\
\hline 123 & NLCD-developed/medium intensity & 0 & 0 & 0 & 0 \\
\hline 124 & NLCD-developed/high intensity & 0 & 0 & 0 & 0 \\
\hline 131 & NLCD-barren & 0 & 0 & 0 & 0 \\
\hline 141 & NLCD-deciduous forest & 0 & 0 & 0 & 0 \\
\hline 142 & NLCD-evergreen forest & 0 & 0 & 0 & 0 \\
\hline 143 & NLCD-mixed forest & 0 & 0 & 0 & 0 \\
\hline 152 & NLCD-shrubland & 0 & 0 & 0 & 0 \\
\hline 171 & NLCD-grassland herbaceous & 0 & 0 & 0 & 0 \\
\hline 175 & CRP & 0 & 0 & 0 & 0 \\
\hline 181 & NLCD-pasture hayland & 0 & 0 & 0 & 0 \\
\hline 182 & NLCD-croplands & 0 & 0 & 0 & 0 \\
\hline 190 & NLCD-woody wetland & 0 & 0 & 0 & 0 \\
\hline 195 & NLCD-herbaceous wetland & 0 & 0 & 0 & 0 \\
\hline 205 & Triticale & 0 & 0 & 0 & 0 \\
\hline 206 & Carrots & 0 & 0 & 0 & 0 \\
\hline 222 & Squash & 0 & 0 & 0 & 0 \\
\hline 224 & Vetch & 0 & 0 & 0 & 0 \\
\hline 225 & Double crop winter wheat/corn & 0 & 0 & 0 & 0 \\
\hline 229 & Pumpkins & 0 & 0 & 0 & 0 \\
\hline 236 & Double crop winter wheat/sorghum & 0 & 0 & 0 & 0 \\
\hline 240 & Double crop soybeans/oats & 0 & 0 & 0 & 0 \\
\hline 241 & Double crop corn/soybeans & 0 & 0 & 0 & 0 \\
\hline 246 & Radishes & 0 & 0 & 0 & 0 \\
\hline 254 & Double crop barley/soybeans & 0 & 0 & 0 & 0 \\
\hline 401 & Temporary wetland & 1 & 1 & 1 & 1 \\
\hline 402 & Seasonal wetland & 1 & 1 & 1 & 1 \\
\hline 403 & Semipermanent wetland & 1 & 1 & 1 & 1 \\
\hline 404 & Permanent wetlands & 0 & 0 & 0 & 0 \\
\hline
\end{tabular}




\title{
Appendix 5. A Geographic Information System Tool to Project Managed and Wild Bees on Any Landscape
}

\author{
Developed by Eric Lonsdorf and Amélie Davis ${ }^{1}$
}

\section{Overview}

The goals of the tool are to assist in identifying high quality habitat for native and managed bees and to improve the ability to anticipate consequences of land-use and land-cover change for bee populations. The tool models native and managed bees' habitat suitability for any land cover. Managed bees and wild bees are modeled separately but each model outputs a spatially explicit map of pollination services. The scores do not factor in weather, insecticides, or other factors that might affect bees, but instead use expert values on suitability of crops and other land cover to provide floral resources to managed bees and floral and nesting resources to wild bees. Also taken into consideration are foraging ranges of bees, seasonality, and bee guilds.

We describe the input files for the managed and wild bee models, how to load the toolbox in ArcGIS, how to run the tool, and how to interpret the output files. Although the tool should be fairly straightforward to use, guidance from a person familiar with the use and application of ArcGIS is recommended for those less comfortable. As such, we assume some working knowledge of ArcGIS and access to the necessary input files. Lastly, we provide example input files for the user to run the model with and familiarize themselves with the format of the input files, as well as see what the output files look like.

NOTE: This tool was written and debugged for ArcGIS 10.2.

\section{Input Files for Managed Bee Model}

Prior to loading the tool, it is important to first make sure you have the necessary input files. There are three files that you need to run the managed bee suitability tool: a raster land cover map, floral suitability estimates, and a kernel distance file. It is recommended that you keep all input files within one folder, in order to easily locate them while running the tool.

Land-cover file.-The land-cover file should be a raster and can be updated using a layer symbology to give coded colors to the various land classes. This file will contain the various land-use and land-cover types within a given area. The tool will output the same area as this input land-cover file, but with values corresponding to seasonal and overall suitability of the land cover for managed or wild bees. The file should be a raster GRID, geotiff, or other raster file type.

In the example folder (named BeeModelsUSGS\Example_Input_Files\) the land-cover file is named lulc. It is in GRID format and has a 40- by 40-meter (m) spatial resolution.

Floral suitability codes.-This file will be used to input the land-use and land-cover suitability values for the different floral seasons. Each land cover is assigned a suitability value ranging from zero to one that specifies how much that land cover provides floral resources for bees. A score of zero indicates bees cannot use any floral resources on that landscape, or that there are no floral resources on that landscape. A score of one indicates this land cover provides the best floral resources. This can be done for up to three seasons because floral output for different land covers can vary by season. The seasons have designated weights in the tool. This file should be in .csv format.

'USGS Cooperative Agreement \# G13AC00378. 
In the example folder, this file is named example_model_input_managedBees.xls. Each land cover has its own row. The spreadsheet must have five columns and a header row. If you are not using some of the seasons, keep the column and numbers in it (set them all to ones or zeros). Here is a screenshot of how the first few rows are set up:

\begin{tabular}{|c|c|c|c|c|c|}
\hline 4 & A & B & $\mathrm{C}$ & D & $\mathrm{E}$ \\
\hline 1 & Land Cover & Code & Season 1 & Season 2 & Season 3 \\
\hline 2 & 1 & Corn & 0 & 0.25 & 0 \\
\hline 3 & 5 & Soybeans & 0 & 0.25 & 0 \\
\hline 4 & 408 & Wetland $160 \mathrm{~m}$ buffer & 0.25 & 0.25 & 0.25 \\
\hline 5 & 23 & Spring Wheat & 0 & 0 & 0 \\
\hline 6 & 171 & NLCD-Grassland Herbaceous & 0.25 & 0.25 & 0.25 \\
\hline 7 & 121 & NLCD-Open Space & 0.5 & 0.5 & 0.5 \\
\hline 8 & 195 & NLCD-Herbaceous Wetland & 1 & 0.75 & 0.5 \\
\hline 9 & 402 & Seasonal Wetland & 0.25 & 0.25 & 0.25 \\
\hline 10 & 401 & Temporary Wetland & 0.25 & 0.25 & 0.25 \\
\hline 11 & 105 & I sructrino & ก 25 & ก 25 & n 25 \\
\hline
\end{tabular}

The user then saves the worksheet as a .csv. In the example, we have saved this file as example_model_input_floral.csv. Of course you can work directly in the .csv format if you wish.

Distance kernel.- This file mimics the foraging distance necessary to predict suitability for bees. The kernel weights are applied to the surrounding land-cover pixels based on how far they are from the center pixel, with closer cells weighted more strongly. This file should be in text format.

In the example folder, you will find three different kernel choices. These kernels were made for a raster with 40- by 40-m pixels and are mimicking foraging ranges of 1.3-, 2.5-, and 5-kilometer $(\mathrm{km})$ radii. These example kernels are named kernel_1_3kmradius.txt, kernel_2_5kmradius.txt, and kernel_5kmradius.txt, respectively. If the spatial resolution of your landcover raster is different than 40 by 40 meters, you need to make new neighborhood kernels. Instructions on how to make this kernel file can be accessed at http://resources.arcgis.com/en/help/main/10.2/index.html\#//005m0000006q000000 or by searching the ArcGIS help for the neighborhood weight object "NbrWeight." If you want larger foraging ranges you will also need to make new neighborhood kernels but note that the larger the radius, the longer the model takes to run.

\section{Input Files for Wild Bee Model}

The input files are essentially the same as the managed bee tool for the wild bee model; however, there is one extra input file that is needed. The four files that you need to run the managed bee suitability tool include a raster land-cover map, floral suitability estimates, a kernel distance file, and nesting suitability estimates (that is, the extra input file).

Land-cover file.-This file will be the same as the managed bee raster land-cover file.

Floral suitability codes. - This file will be the same as the managed bee floral suitability values.

Distance kernel.-This file will be the same as the managed bee distance kernel file.

Nesting suitability file.-This will be a .csv document, detailing nesting suitability for a variety of guilds. For example, it is possible to include nesting suitability values for up to four nesting types such as ground, cavity, stem, and wood nesting bees. 
In the example folder, this file is named example model_input_wildBees.xls. Each land cover has its own row. The spreadsheet must have six columns and a header row. If you are not using some of the guilds, keep the column and numbers in it (set them all to ones or zeros). Here is a screenshot of how the first few rows are set up:

\begin{tabular}{|c|c|c|c|c|c|c|}
\hline$\Delta$ & A & B & C & D & $\mathrm{E}$ & $\mathrm{F}$ \\
\hline 1 & Land Cover & Code & Ground & Cavity & Stem & Wood \\
\hline 2 & & Corn & 0.25 & 0.25 & 0.25 & 0 \\
\hline 3 & & Soybeans & 0.25 & 0.25 & 0.25 & 0 \\
\hline 4 & 408 & Wetland $160 \mathrm{~m}$ buffer & 0.25 & 0.25 & 0.25 & 0 \\
\hline 5 & 23 & Spring Wheat & 0.25 & 0.25 & 0.25 & 0 \\
\hline 6 & 171 & NLCD-Grassland Herbaceous & 1 & 1 & 1 & 0.25 \\
\hline 7 & 121 & NLCD-Open Space & 1 & 1 & 1 & 0.25 \\
\hline
\end{tabular}

The user then saves the worksheet as a .csv. In the example, we have saved this file as example_model_input_nesting.csv. Of course you can work directly in the .csv format if you wish.

\section{Loading the Tool in GIS}

We have designed the tool to be used like other tools in ArcGIS and so it is part of a custom-made toolbox. We recommend placing the toolbox that came from the zipped folder in your ArcGIS folder within your "Documents" folder. Please make sure that the python files, "ManagedBeeSuitabilityModel.py," and "WildBeeSuitabilityModel.py" are also with the toolbox. For example, on my computer the files are located in "C:IUsers\Documents $\backslash$ ArcGIS $\backslash$ Toolbox_and_Python_CodelUSGS_Bee_Models.tbx." Once you have done this, you need to open ArcGIS 10.2 and add the toolbox to the other available toolboxes.

Following the help file for ArcGIS:

\section{Using the ArcToolbox window}

Desktop \% Geoprocessing

In any ArcGIS for Desktop application, you open the ArcToolbox window with the Show/Hide ArcToolbox Window button found on the standard toolbar or by clicking Geoprocessing > ArcToolbox.

5 Legacy: Prior to ArcGIS 10, the ArcToolbox window had Search, Index, and Results tabs. These have been replaced by the Search window and the Results window, available from the Geoprocessing menu.

\section{Key features of the ArcToolbox window}

\section{You can customize the contents by adding and removing toolboxes}

To add any toolbox to the ArcToolbox window, right-click the ArcToolbox entry and click Add Toolbox as illustrated below. Browse to the location containing the toolbox you want to add and select the toolbox.

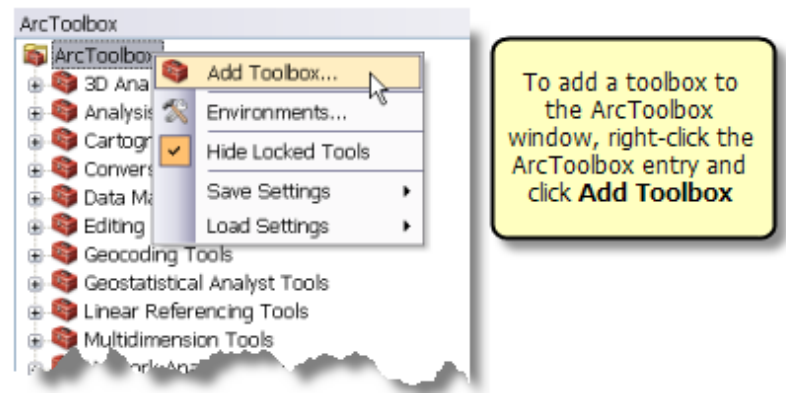


Then, you will be asked to navigate to the location of the custom toolbox, and you should be able to locate the toolbox, as shown below. Once you highlight the toolbox, click open and the toolbox should now show up in the list of tools available to you.

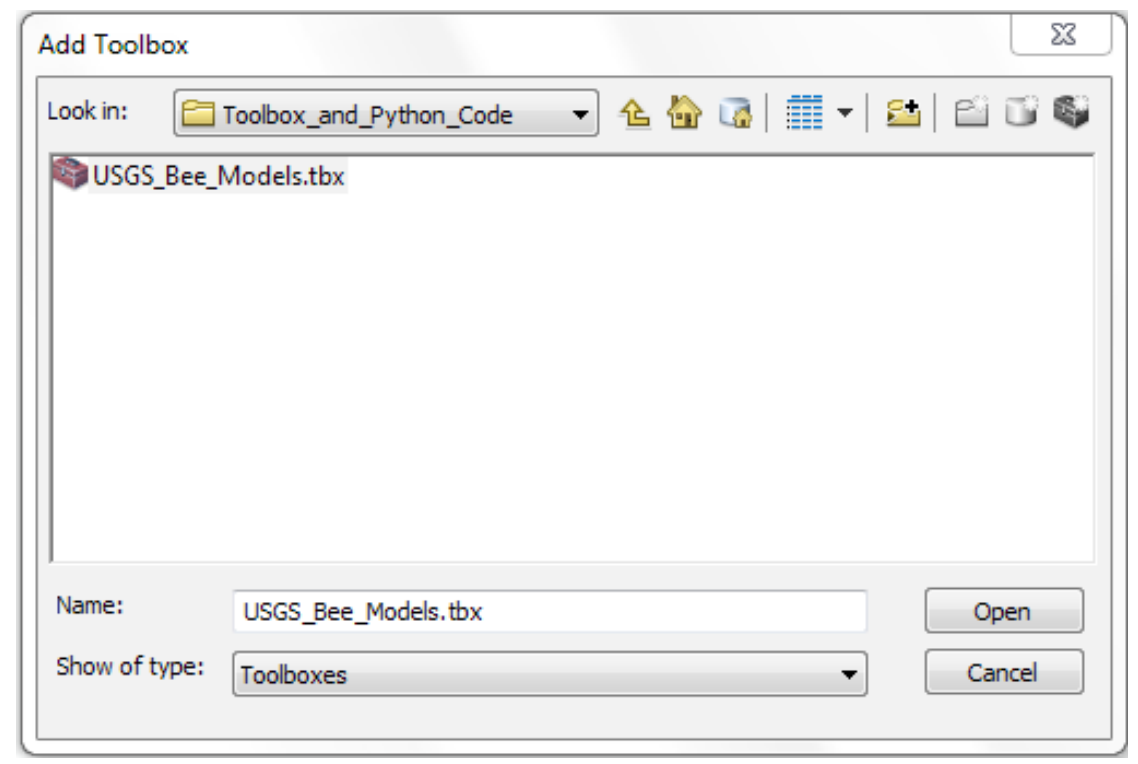

Your new toolbox set should look something like this with "USGS_Bee_Models" now included:

\begin{tabular}{|c|c|}
\hline ArcToolbox & $\square \times$ \\
\hline 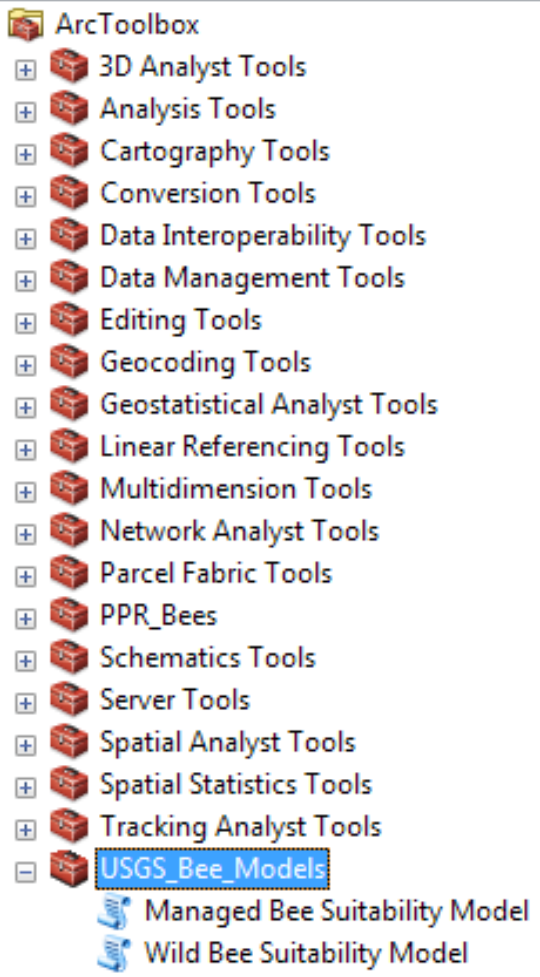 & \\
\hline
\end{tabular}

IMPORTANT: Once you've added the tool, you should check to make sure that the tool references the correct location for the python code that runs the analysis. To do this, right click on the "Managed Bee Suitability Model" icon, and select "Properties." Then select the "Source" tab. Locate the script file in the same place as the toolbox and click "OK." Do the same for the "Wild Bee Suitability Model." 


\title{
Loading the Input Files
}

Prior to running the tool, we advise adding the necessary input layers to the Table of Contents. Here are instructions to do so from ArcGIS:

\section{Adding layers to a map}

\author{
Desktop $\approx$ Mapping
}

Each layer references a dataset that is stored in a geodatabase, coverage, shapefile, raster, and so on. It's easy to add layers to a mapyou simply select a dataset and drag it from the Catalog or Search window onto your map or add a dataset using the Add Data button.

Once each layer is added to your map, you'll typically set the symbology and labeling properties and organize the drawing order of the layers in your table of contents to make your map work well.

If your data is stored in a format supported by ArcMap, you can add it directly to your map as a layer. If your data isn't stored in a supported format, you can use the data conversion utilities in ArcToolbox or the Data Interoperability extension to convert practically any data and display it in your map.

\section{Adding map layers}

There are a number of ways to add map layers. Each of them is covered here.

\section{Adding a dataset}

To create a new map layer, simply add a dataset to your map, globe, or 3D scene. There are a few ways to add datasets:

- Using the Add Data button-Click the Add Data button $\downarrow$ and navigate to the desired dataset. Then select and add it to your map.

In the "Example_Input_Files" folder you will find example input files necessary to run the tool. You can select your landuse and land-cover (lulc) file and load it into ArcMap. We show here how to load the example lulc file we provided with the tool (it is located in the "... BeeModels_USGS\Example_Input_Files" folder).

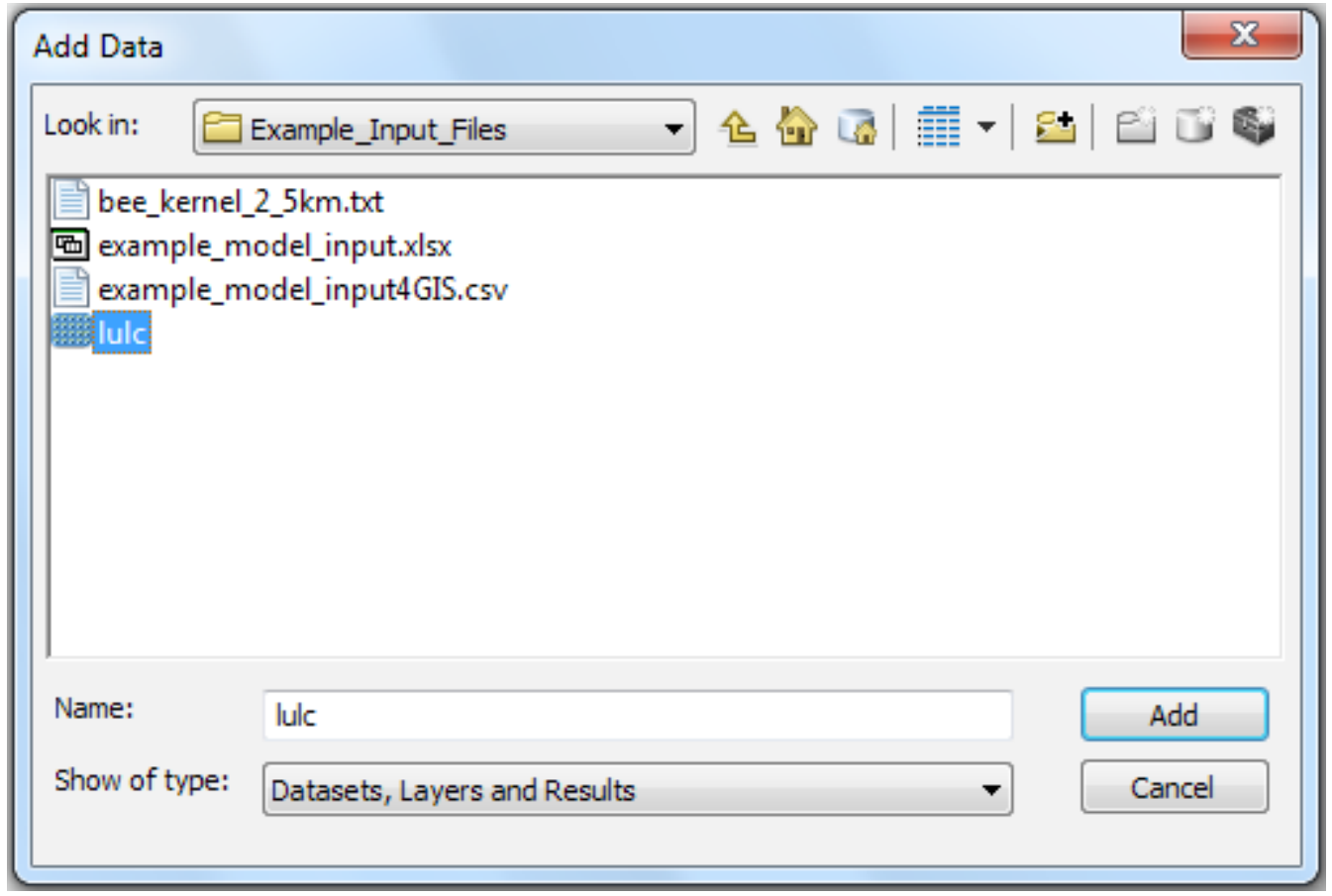


The example land-cover raster loaded into ArcMap should look something like this:

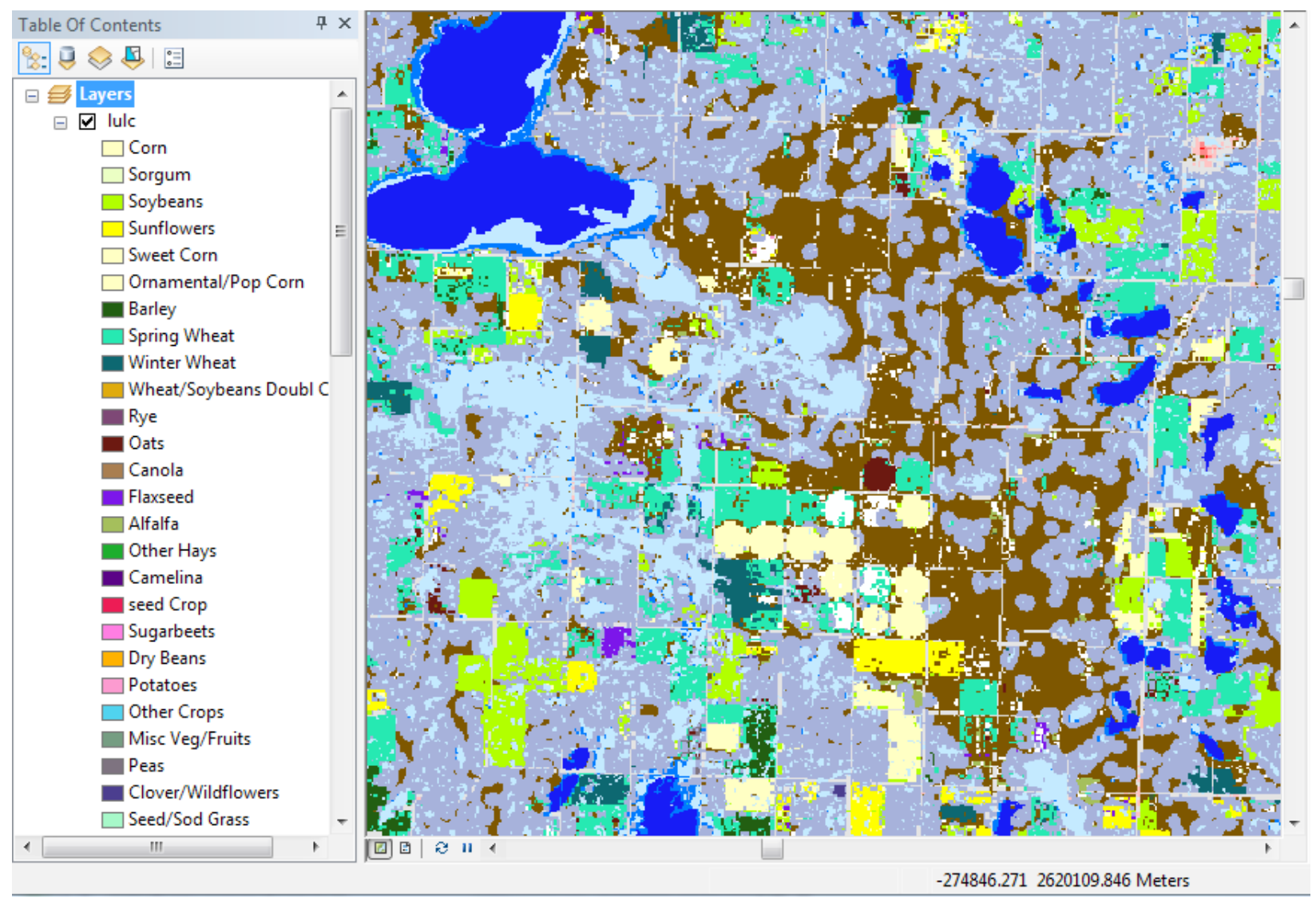

After you have loaded your tool and have your input files ready, create an output folder in an easily accessible location in order to have your model outputs go to the same place once you run the model.

\section{Running the Managed Bee Tool}

Once you have added the necessary lulc layer, you are ready to use the tool. Expand the toolbox and double-click on the script labeled "Managed Bee Suitability Model." First, you must tell the tool where to locate the input files. By navigating with the folder button, you can locate each file within your Table of Contents in ArcMap. 
Here is a screen shot and the description of the additional information is described below it:

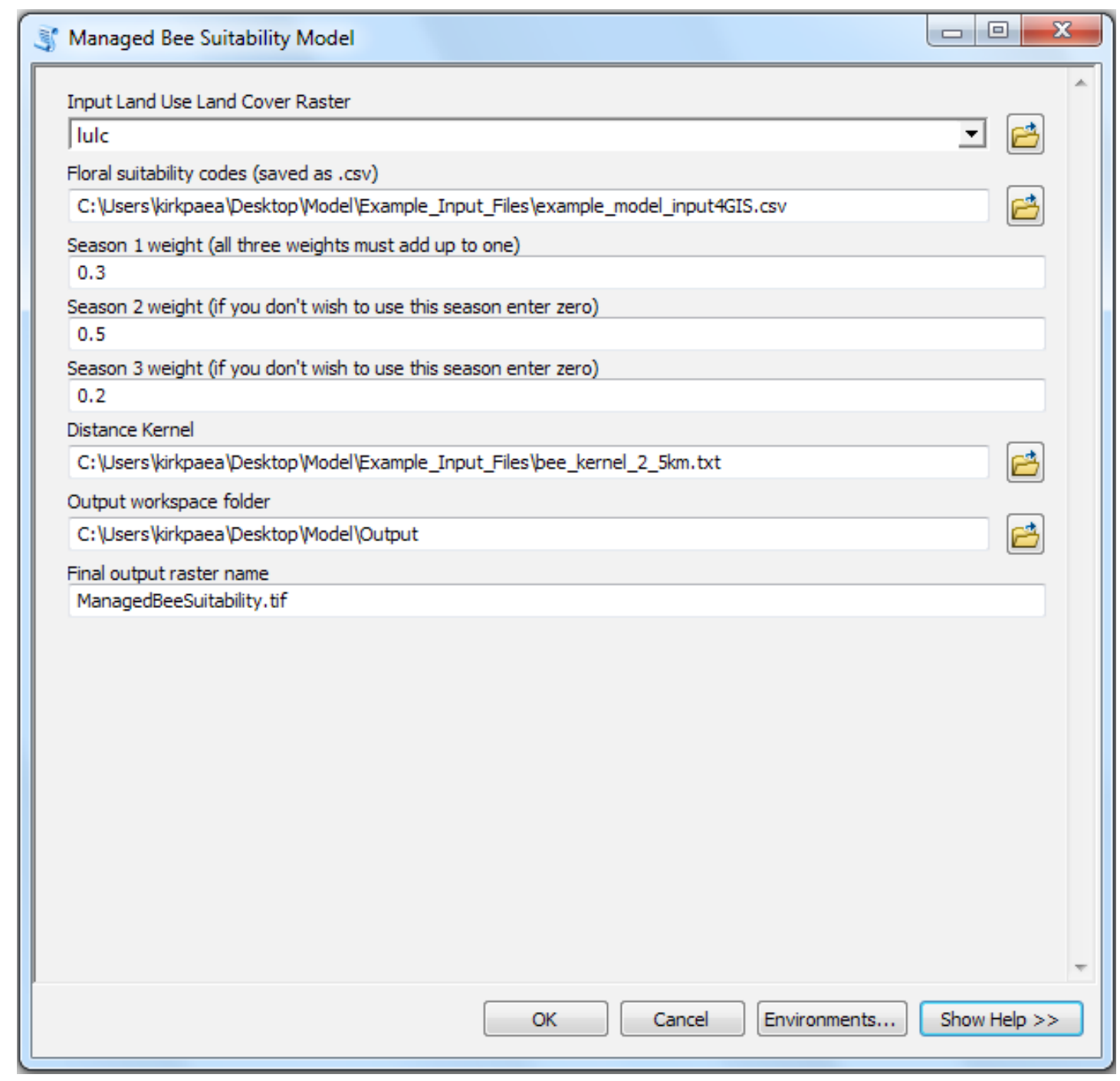

Seasonal Weights for Suitability.-Apart from the input files, other user inputs include specifying the seasonal weights and names for an output folder and an output file. These values will already be filled in once you open the tool but they are just suggestions. In this case, Season 2 (summer) receives the highest weight of 0.5 , because floral resources are most valuable to bees during this time, followed by Season 1 (spring) at 0.3 and Season 3 (fall) at 0.2. You can modify these according to the importance of the floral blooms to bees in your study region but the values for the weighted seasons must total to 1 . Season 1 weight must always have a value greater than zero (up to one).

Designating the output files.-The user must have an output folder where intermediary files created by the model will be saved as well as the final output file. Also, make sure to update the "Final output raster name" each time you run the model. Once you have directed the tool to the location of the necessary input files and provided the additional three inputs required, click "OK" to run the analysis. 
You should see the analysis running, and assuming it ran successfully, the dialogue box should look something like this:

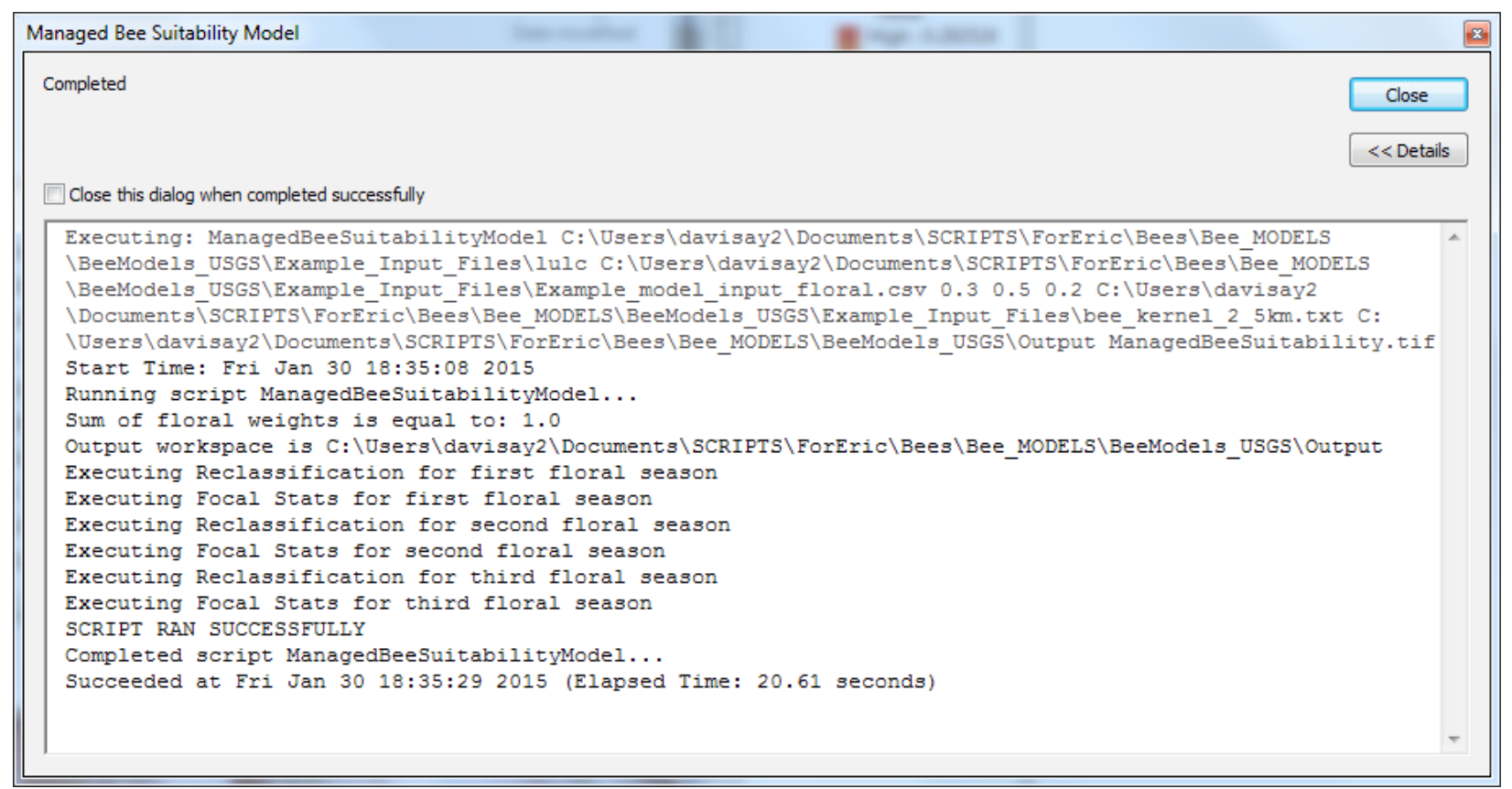

\section{Viewing the Output Files}

The tool creates several output layers to the output folder location. To view them, you'll need to add them to the ArcMap document as you did the input layer. Below is an example of the output layers when the tool is run with the example files:

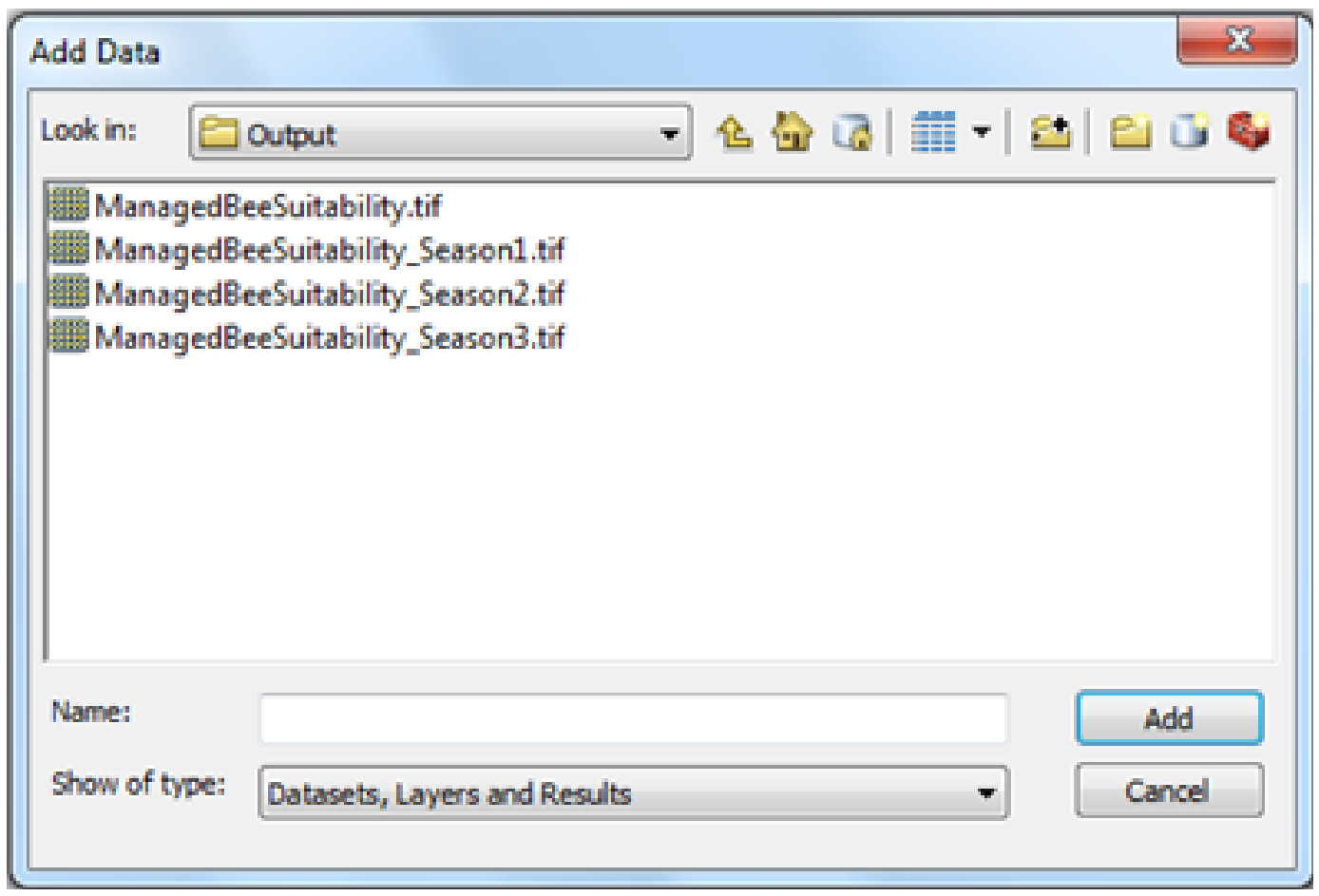


ManagedBeeSuitability.tif.-This file depicts the overall habitat suitability for managed bees (for example combining the three seasonal outputs using the user specified weights). Higher values indicate higher suitability. Below is an example output of the ManagedBeeSuitability.tif:

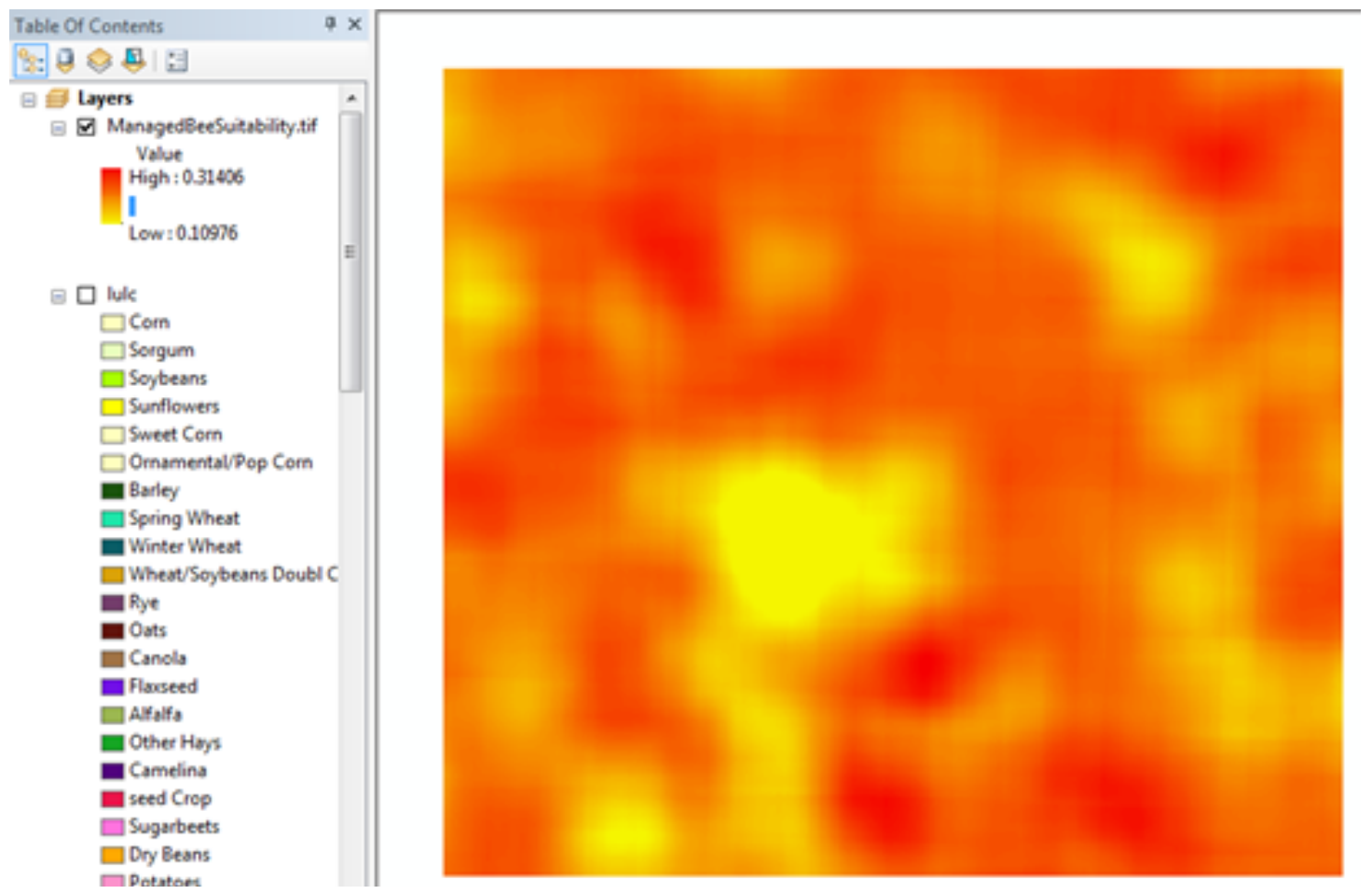

ManagedBeeSuitability_Season1._-This file depicts the floral resource suitability for managed bees in the spring. Below is an example output of the ManagedBeeSuitability_Season1.tif:

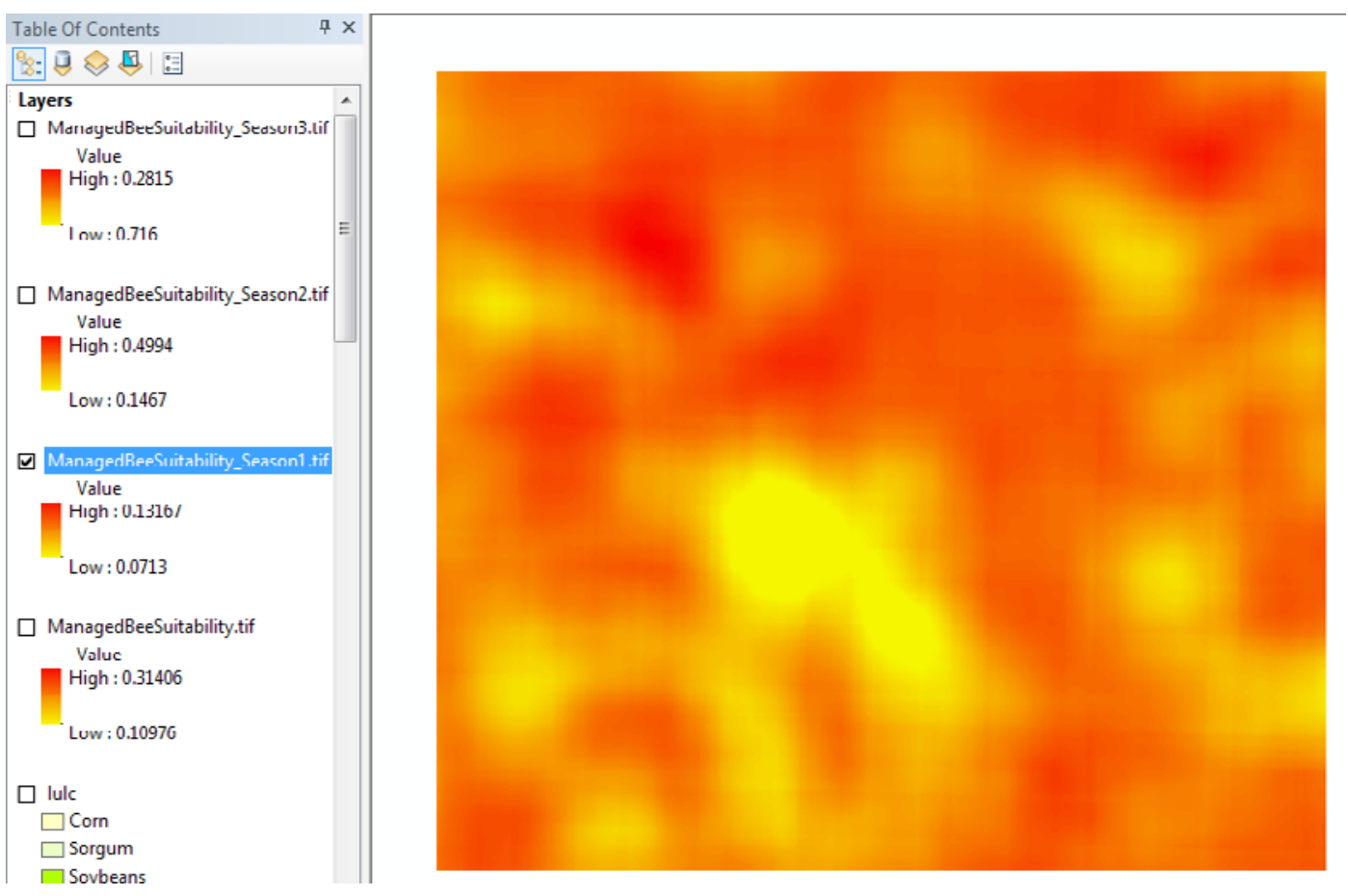


ManagedBeeSuitability_Season2._-This file depicts the floral resource suitability for managed bees in the summer. Below is an example output of the ManagedBeeSuitability_Season2.tif:

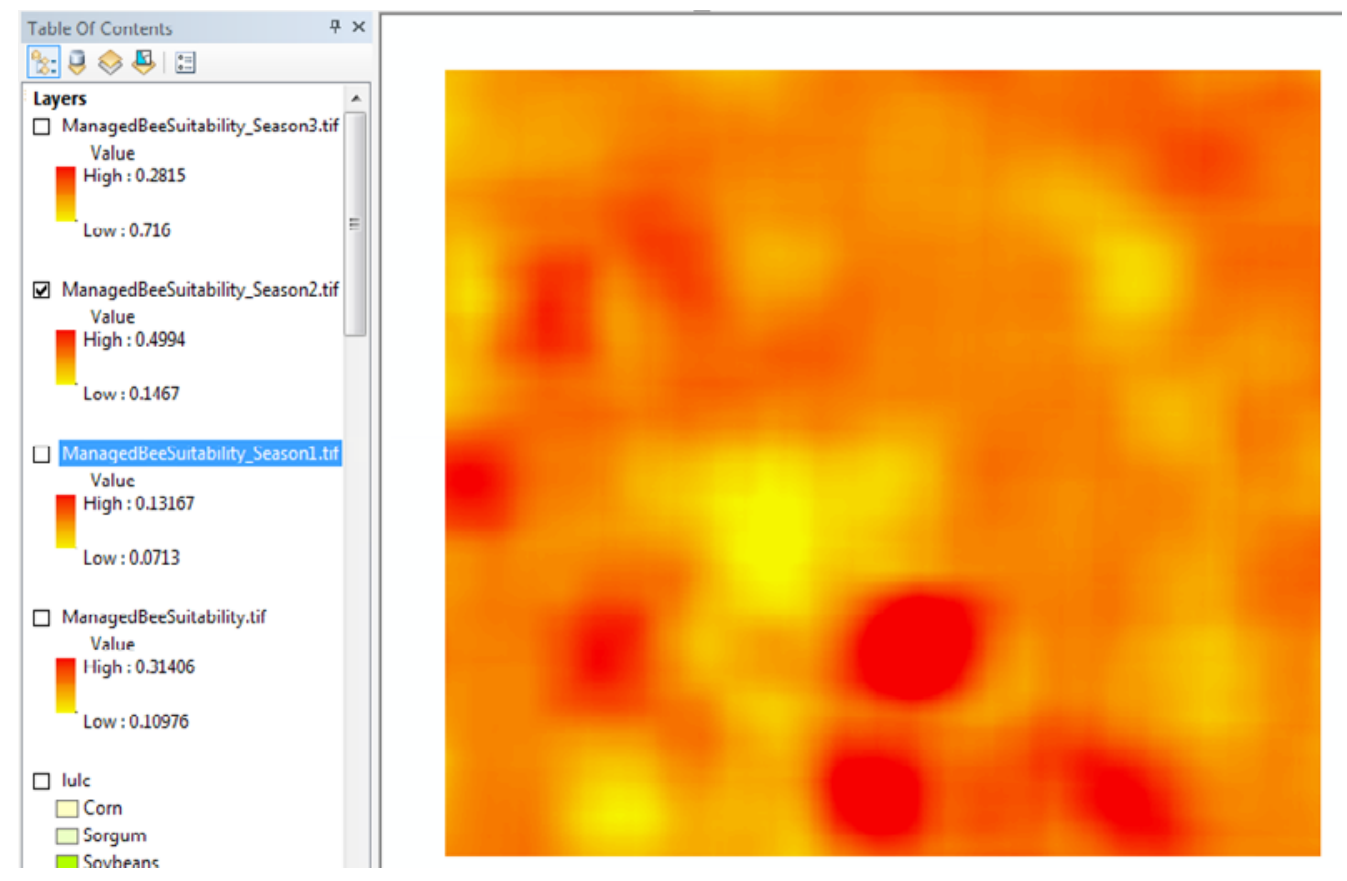

ManagedBeeSuitability_Season3.tif._- This file depicts the floral resource suitability for managed bees in the fall. Below is an example output of the ManagedBeeSuitability_Season3.tif:

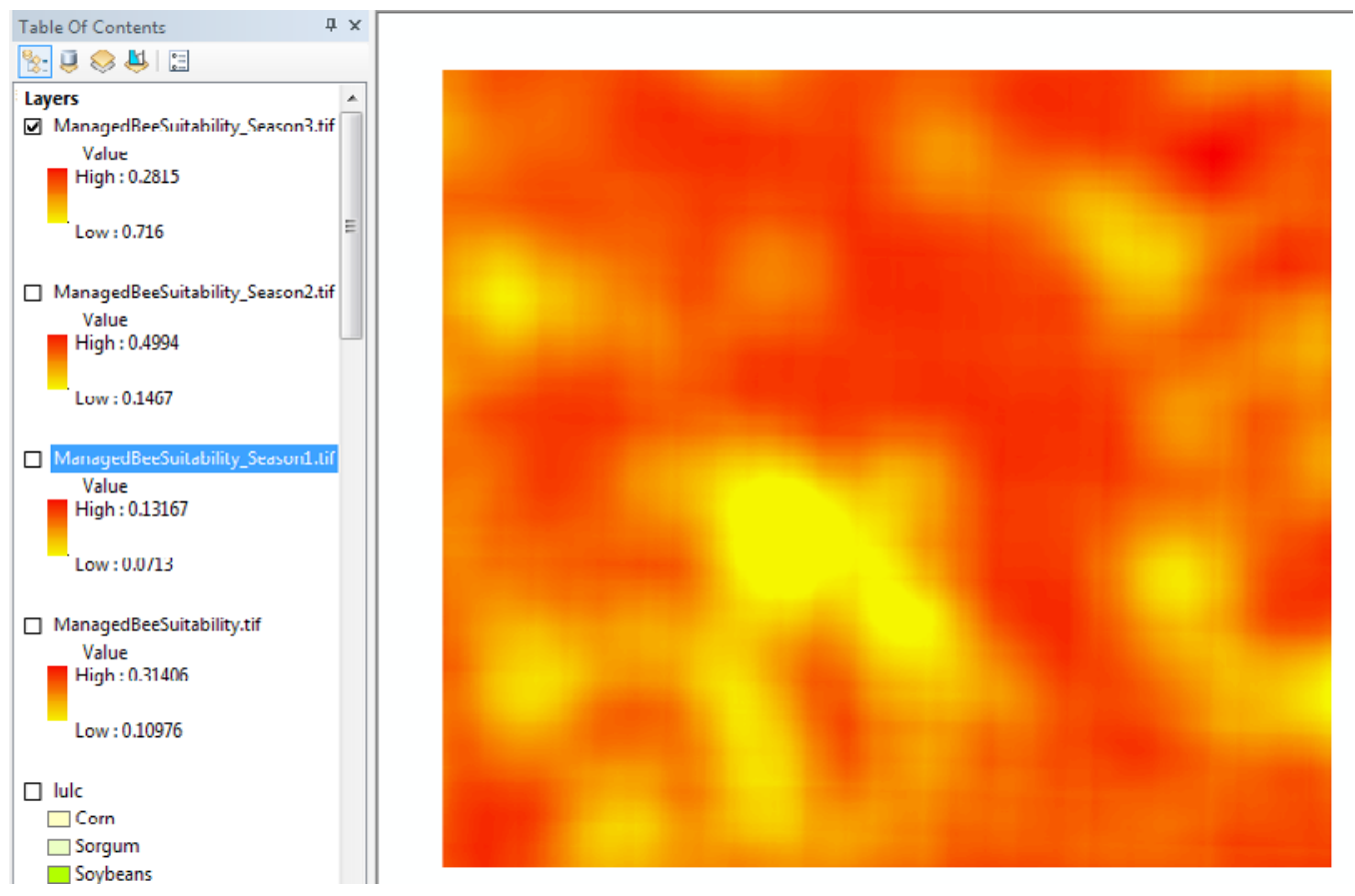




\section{Running the Wild Bee Tool}

The Wild Bee Suitability Tool has the same inputs as the Managed Bee Suitability Tool. The only additional inputs are the following:

Nesting suitability codes.-This file will be used to input the land-use and land-cover suitability values for the different guilds. This file should be in .csv format and is similar to the Floral Nesting Suitability Codes file except that each land use and land cover is rated as a function of how good of a nesting ground it provides for up to four different bee guilds.

Weights for guilds.-The user needs to specify weights for each guild. These values will already be filled in once you open the tool. You may decide to use just one, two, three, or up to four different guilds. If you do not wish to use that guild, enter a weight of zero. The weights represent the proportion of bees in each of these guilds that you would expect to find in your study region. In the example, all four guilds are represented equally in this study region and are thus assigned a weight of 0.25 . The values for the weighted guilds must total to 1 . Guild A weight must always have a value greater than zero (up to one).

Here is an example of the inputs for the Wild Bee Suitability Model:

\begin{tabular}{|c|c|c|}
\hline Ij Wild Bee Suitability Model & \multicolumn{2}{|c|}{\begin{tabular}{|l|l|l|}
$口$ & 回 & $x$ \\
\end{tabular}} \\
\hline Input Land Use Land Cover Raster & \multicolumn{2}{|r|}{ A } \\
\hline $\mid C: \backslash$ Users $\backslash$ davisay2 $\backslash$ Documents $\backslash S C R I P T S \backslash F o r E r i c \backslash B e e s \backslash$ Bee_MODELS\BeeModels_USGS $\backslash$ Example_Input_Files $\backslash$ Iulc & $=\theta$ & \\
\hline \multicolumn{3}{|l|}{ Floral suitability codes (saved as .csv) } \\
\hline 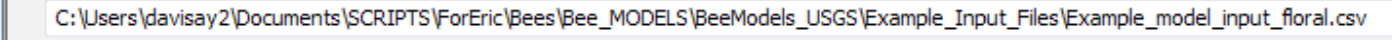 & E & \\
\hline \multicolumn{3}{|l|}{ Season 1 weight (enter values between zero and one) } \\
\hline \multicolumn{3}{|l|}{0.3} \\
\hline \multicolumn{3}{|l|}{ Season 2 weight (if you don't wish to use this season enter zero) } \\
\hline 0.5 & & \\
\hline \multicolumn{3}{|l|}{ Season 3 weight (if you don't wish to use this season enter zero) } \\
\hline \multicolumn{3}{|l|}{0.2} \\
\hline \multicolumn{3}{|l|}{ Nesting suitability codes (saved as .csv) } \\
\hline 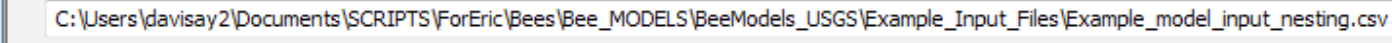 & E & \\
\hline \multicolumn{3}{|l|}{ Guild A weight (enter a value between zero and one) } \\
\hline \multicolumn{3}{|l|}{0.25} \\
\hline \multirow{2}{*}{\multicolumn{3}{|c|}{$\begin{array}{l}\text { Guild B weight (if you don't wish to use this guild enter zero) } \\
0.25\end{array}$}} \\
\hline & & \\
\hline \multicolumn{3}{|l|}{ Guild C weight (if you don't wish to use this weight enter zero) } \\
\hline \multicolumn{3}{|l|}{0.25} \\
\hline \multicolumn{3}{|l|}{ Guild D weight (if you don't wish to use this weight enter zero) } \\
\hline \multicolumn{3}{|l|}{0.25} \\
\hline \multicolumn{3}{|l|}{ Distance Kernel } \\
\hline 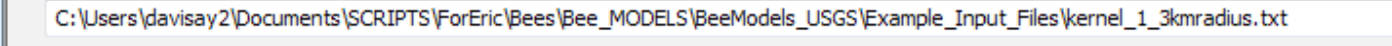 & 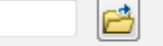 & \\
\hline \multicolumn{3}{|l|}{ Output workspace folder } \\
\hline 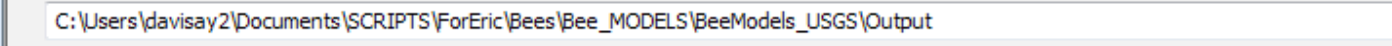 & E & \\
\hline \multicolumn{3}{|l|}{ Final output raster name } \\
\hline WildBeeSuitability.tif & & \\
\hline Environments... & Show Help $\gg$ & \\
\hline
\end{tabular}


You should see the analysis running, and assuming it ran successfully, the dialogue box should look something like this:

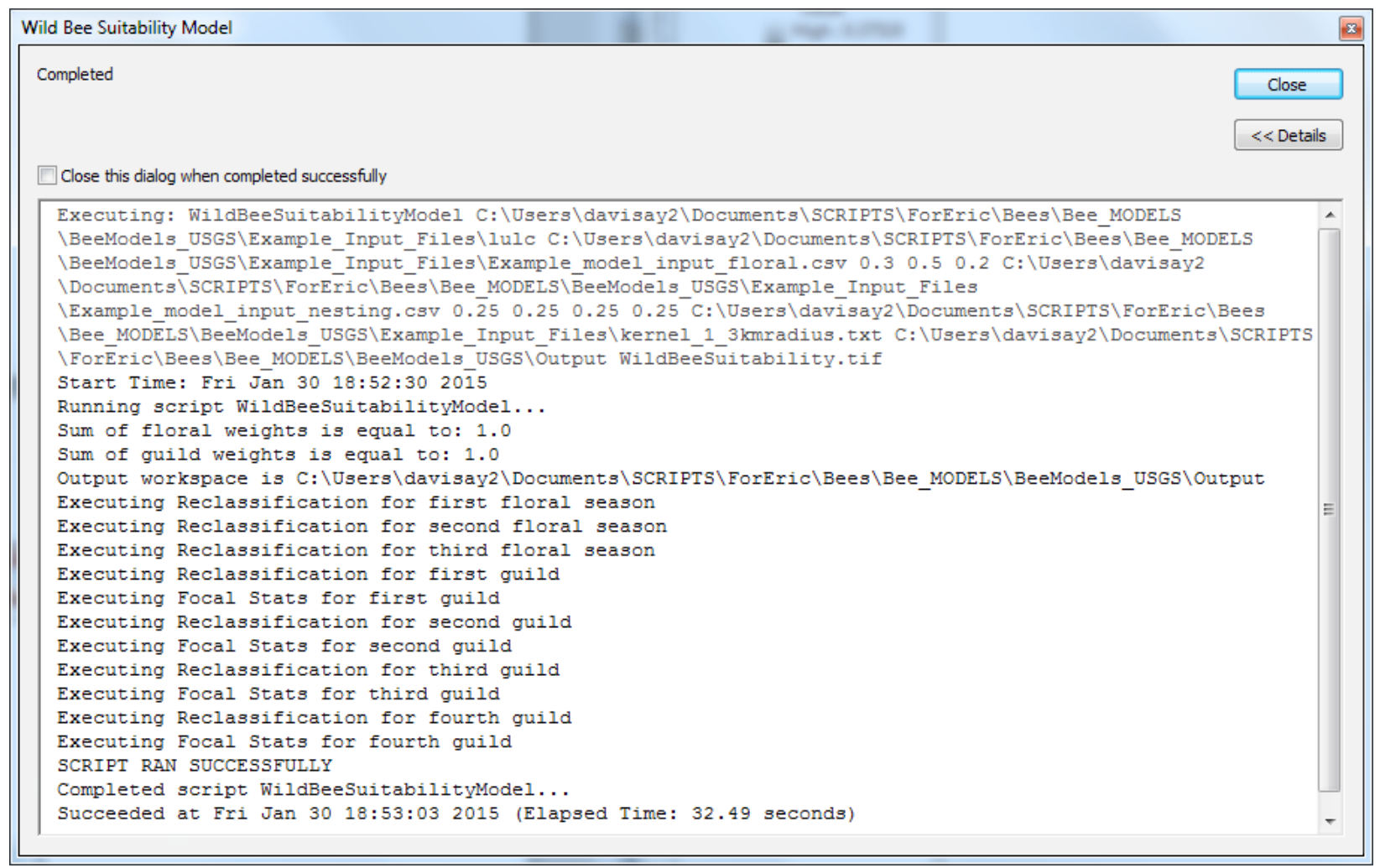




\section{Viewing the Output Files}

The tool creates one output layer to the output folder location. To view it, you will need to add it to the ArcMap document as you did the input layer.

WildBeeSuitability.tif.-This file depicts the overall habitat suitability for wild bees. Higher values indicate higher suitability.

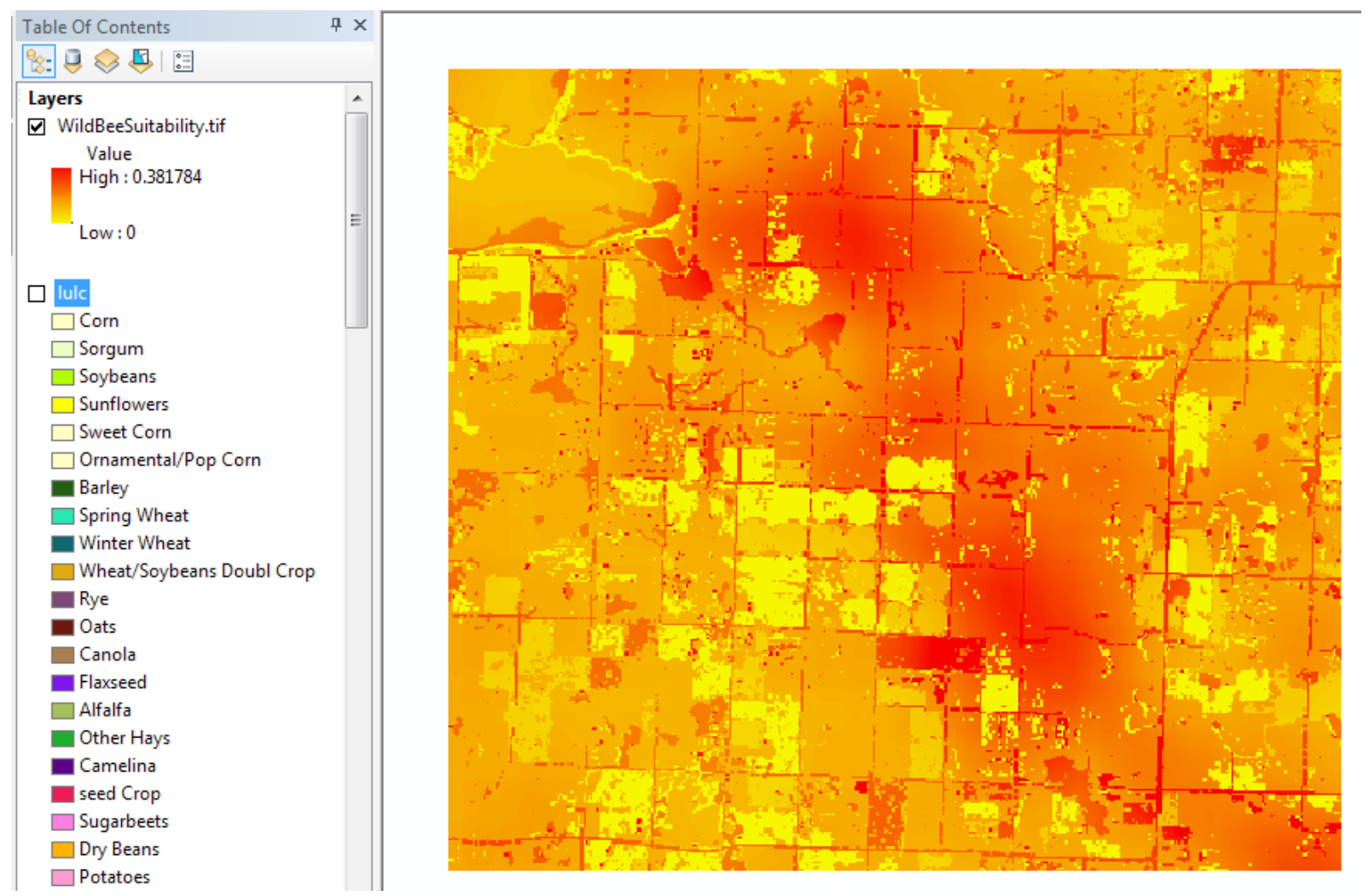




\section{Appendix 6. Floral Resource Values for Land-Cover Types used in Integrated Valuation of Ecosystem Services and Tradeoffs (InVEST) Managed Bee Model Runs}

Table 6-1. Floral resource values for land-cover types used in Integrated Valuation of Ecosystem Services and Tradeoffs (INVEST) managed bee model runs.

[NLCD, National Land Cover Data]

\begin{tabular}{|c|c|c|c|c|}
\hline Code & Land cover & Season 1 & Season 2 & Season 3 \\
\hline 1 & Corn & 0.00 & 0.25 & 0.00 \\
\hline 4 & Sorghum & 0.00 & 0.00 & 0.00 \\
\hline 5 & Soybeans & 0.00 & 0.25 & 0.00 \\
\hline 6 & Sunflowers & 0.00 & 1.00 & 0.00 \\
\hline 12 & Sweet corn & 0.00 & 0.25 & 0.00 \\
\hline 13 & Ornamental/pop corn & 0.00 & 0.25 & 0.00 \\
\hline 21 & Barley & 0.00 & 0.00 & 0.00 \\
\hline 22 & Durum wheat & 0.00 & 0.00 & 0.00 \\
\hline 23 & Spring wheat & 0.00 & 0.00 & 0.00 \\
\hline 24 & Winter wheat & 0.00 & 0.00 & 0.00 \\
\hline 25 & Other small grains & 0.00 & 0.00 & 0.00 \\
\hline 26 & Wheat/soybeans double crop & 0.00 & 0.25 & 0.00 \\
\hline 27 & Rye & 0.00 & 0.00 & 0.00 \\
\hline 28 & Oats & 0.00 & 0.00 & 0.00 \\
\hline 29 & Millet & 0.00 & 0.00 & 0.00 \\
\hline 31 & Canola & 0.00 & 1.00 & 0.00 \\
\hline 32 & Flaxseed & 0.00 & 1.00 & 0.00 \\
\hline 33 & Safflower & 0.00 & 1.00 & 0.00 \\
\hline 34 & Rape seed & 0.00 & 1.00 & 0.00 \\
\hline 35 & Mustard & 0.50 & 1.00 & 0.25 \\
\hline 36 & Alfalfa & 0.00 & 1.00 & 0.50 \\
\hline 37 & Other hays & 0.00 & 0.75 & 0.50 \\
\hline 38 & Camelina & 0.00 & 1.00 & 0.00 \\
\hline 39 & Seed crop & 0.25 & 0.25 & 0.25 \\
\hline 41 & Sugarbeets & 0.00 & 0.00 & 0.00 \\
\hline 42 & Dry beans & 0.00 & 0.25 & 0.00 \\
\hline 43 & Potatoes & 0.00 & 0.00 & 0.00 \\
\hline 44 & Other crops & 0.00 & 0.00 & 0.00 \\
\hline 47 & Miscellaneous vegetables/fruits & 0.25 & 0.25 & 0.25 \\
\hline 52 & Lentils & 0.00 & 0.00 & 0.00 \\
\hline 53 & Peas & 0.00 & 0.75 & 0.00 \\
\hline 57 & Herbs & 0.00 & 1.00 & 0.75 \\
\hline 58 & Clover/wildflowers & 0.75 & 1.00 & 0.50 \\
\hline 59 & Seed/sod grass & 0.00 & 0.00 & 0.00 \\
\hline 60 & Switchgrass & 0.00 & 0.00 & 0.00 \\
\hline 61 & Fallow/idle cropland & 0.50 & 0.50 & 0.50 \\
\hline 68 & Apples & 1.00 & 0.00 & 0.00 \\
\hline 69 & Grapes & 0.00 & 0.00 & 0.00 \\
\hline
\end{tabular}


Table 6-1. Floral resource values for land-cover types used in Integrated Valuation of Ecosystem Services and Tradeoffs (INVEST) managed bee model runs.-Continued

[NLCD, National Land Cover Data]

\begin{tabular}{|c|c|c|c|c|}
\hline Code & Land cover & Season 1 & Season 2 & Season 3 \\
\hline 87 & Wetlands & 0.25 & 0.50 & 0.25 \\
\hline 111 & NLCD-open water & 0.00 & 0.00 & 0.00 \\
\hline 121 & NLCD-open space & 0.50 & 0.50 & 0.50 \\
\hline 122 & NLCD-developed/low intensity & 0.50 & 0.50 & 0.50 \\
\hline 123 & NLCD-developed/medium intensity & 0.25 & 0.25 & 0.25 \\
\hline 124 & NLCD-developed/high intensity & 0.00 & 0.00 & 0.00 \\
\hline 131 & NLCD-barren & 0.00 & 0.00 & 0.00 \\
\hline 141 & NLCD-deciduous forest & 0.75 & 0.25 & 0.00 \\
\hline 142 & NLCD-evergreen forest & 0.00 & 0.00 & 0.00 \\
\hline 143 & NLCD-mixed forest & 0.75 & 0.25 & 0.00 \\
\hline 152 & NLCD-shrubland & 0.25 & 0.25 & 0.25 \\
\hline 171 & NLCD-grassland herbaceous & 0.25 & 0.25 & 0.25 \\
\hline 190 & NLCD-woody wetland & 0.50 & 0.50 & 0.25 \\
\hline 195 & NLCD-herbaceous wetland & 1.00 & 0.75 & 0.50 \\
\hline 205 & Triticale & 0.00 & 0.00 & 0.00 \\
\hline 206 & Carrots & 0.00 & 0.00 & 0.00 \\
\hline 222 & Squash & 0.00 & 1.00 & 0.00 \\
\hline 224 & Vetch & 0.00 & 0.75 & 0.25 \\
\hline 225 & Double crop winter wheat/corn & 0.00 & 0.25 & 0.00 \\
\hline 229 & Pumpkins & 0.00 & 1.00 & 0.00 \\
\hline 236 & Double crop winter wheat/sorghum & 0.00 & 0.00 & 0.00 \\
\hline 240 & Double crop soybeans/oats & 0.00 & 0.25 & 0.00 \\
\hline 241 & Double crop corn/soybeans & 0.00 & 0.25 & 0.00 \\
\hline 246 & Radishes & 0.00 & 0.00 & 0.00 \\
\hline 254 & Double crop barley/soybean & 0.00 & 0.25 & 0.00 \\
\hline 401 & Temporary wetland & 0.25 & 0.25 & 0.25 \\
\hline 402 & Seasonal wetland & 0.25 & 0.25 & 0.25 \\
\hline 403 & Semipermanent wetland & 0.50 & 0.50 & 0.25 \\
\hline 404 & Permanent wetlands & 0.50 & 0.50 & 0.25 \\
\hline 405 & Lacustrine & 0.25 & 0.25 & 0.25 \\
\hline 406 & Riverine & 0.25 & 0.25 & 0.25 \\
\hline 407 & Artificially flooded wetland & 0.00 & 0.00 & 0.00 \\
\hline 408 & Wetland 160-meter buffer & 0.25 & 0.25 & 0.25 \\
\hline
\end{tabular}




\section{Appendix 7. Select Subarea Settings Used in Agricultural Policy/ Environmental Extender (APEX) Runs}

Table 7-1. Select subarea settings used in Agricultural Policy/Environmental Extender (APEX) runs.

[USLE, Universal Soil Loss Equation]

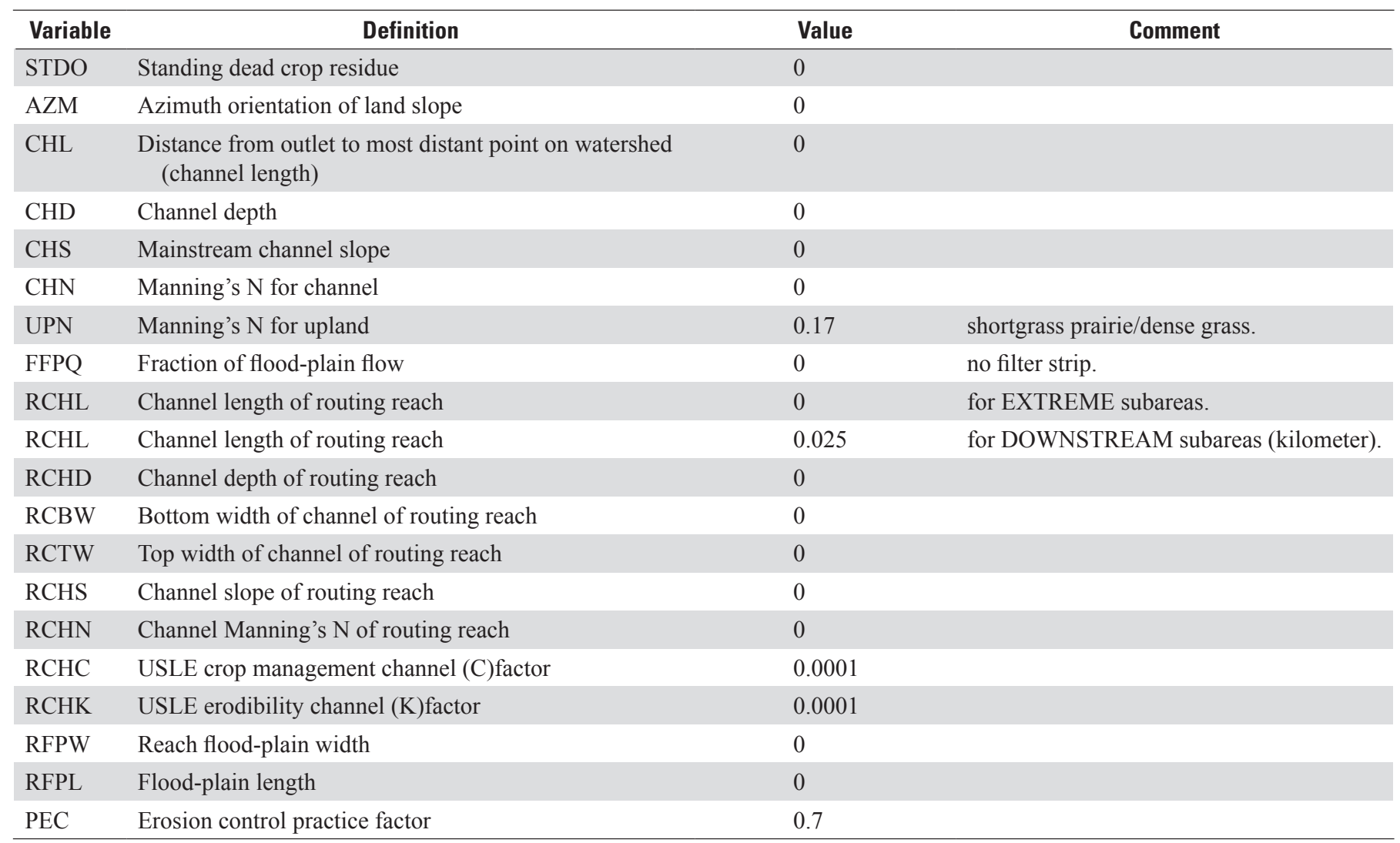




\section{Appendix 8. Select Control File Settings Used in Agricultural Policy/ Environmental Extender (APEX) Runs}

Table 8-1. Select control file settings used in Agricultural Policy/Environmental Extender (APEX) runs.

$[\mathrm{m} / \mathrm{m}$, meter per minute; $\mathrm{mm} / \mathrm{h}$, millimeter per hour; $\mathrm{mm}$, millimeter]

\begin{tabular}{|c|c|c|c|}
\hline Variable & Definition & Value & Comment \\
\hline IET & Potential evapotranspiration equation code & 4 & \\
\hline ISCN & Stochastic CN estimator code & 0 & \\
\hline ITYP & Peak rate estimate code & 3 & \\
\hline ISTA & Static soil code & 0 & \\
\hline IHUS & Automatic heat unit scheduling & 0 & \\
\hline NVCNO & Non-varying $\mathrm{CN}-\mathrm{CN} 2$ used & 4 & \\
\hline QG & Channel capacity flow rate & 1 & to force flood-plain flow. \\
\hline QCF & Exponent in watershed area flow rate equation & 0.5 & \\
\hline CHSO & Average upland slope $(\mathrm{m} / \mathrm{m})$ in watershed & 0.099 & average of upland subarea slope \\
\hline BWD & Channel bottom width/depth, in $\mathrm{m} / \mathrm{m}$ & 5 & \\
\hline $\mathrm{FCW}$ & Flood-plain width/channel width, in $\mathrm{m} / \mathrm{m}$ & 10 & \\
\hline FPSC & Flood-plain saturated hydraulic conductivity, in $\mathrm{mm} / \mathrm{h}$ & 1 & unable to find good data for this. \\
\hline GWSO & Maximum ground water storage, in $\mathrm{mm}$ & 50 & \\
\hline RFTO & Ground water residence time, in days & 0 & \\
\hline DIAM & Soil particle diameter & 50 & microns. \\
\hline
\end{tabular}


Publishing support provided by: Rolla Publishing Service Center

For more information concerning this publication, contact: Director, USGS Northern Prairie Wildlife Research Center 8711 37th Street Southeast Jamestown, North Dakota 58401 (701) 253-5553

Or visit the Northern Prairie Wildlife Research Center Web site at: http://www.npwrc.usgs.gov/ 

